\title{
Meiobenthos of the Deep Northeast Atlantic
}

M. Vincx, ${ }^{1}$ B.J. Bett, ${ }^{2}$ A. Dinet, ${ }^{3}$ T. Ferrero, ${ }^{4}$ A.J. Gooday, ${ }^{2}$ P.J.D. Lambshead, $^{4}$ O. Pfannkuche, ${ }^{6}$ T. Soltwedel ${ }^{5}$ and A. Vanreusel ${ }^{1}$

${ }^{1}$ University of Gent, Zoology Institute, Marine Biology Section, $K$ L. Ledeganckstraat 35, B 9000 Gent, Belgium.

${ }^{2}$ Institute of Oceanographic Sciences Deacon Laboratory, Brook Road, Wormley, Godalming, Surrey GU8 5UB, UK.

${ }^{3}$ Laboratoire Arago, F 66650 Banyuls sur Mer, France.

${ }^{4}$ Department of Zoology, The Natural History Museum, Cromwell Road, London SW7 5BD, UK.

${ }^{5}$ Institut für Hydrobiologie und Fischereiwissenschaft, Universität

Hamburg, Zeiseweg 9, 22765, Germany.

${ }^{6}$ Forschungzentrum für Marine Geowissenschaften, GEO MAR Abt. Marine Umweltgeologie, Universität Kiel, Wischhofstr. 1-3, Kiel, Germany

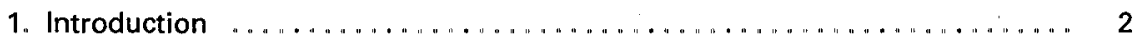

2. Meiobenthos in the Northeast Atlantic . . . . . . n n , . . . . . . . . . " . . . 4

2.1. Physiographic setting . . . . . . . . . . . . . . . . 4

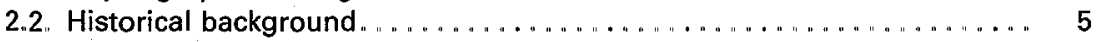

2.3. Sampling areas

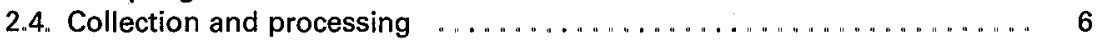

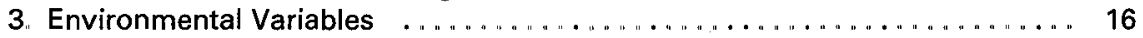

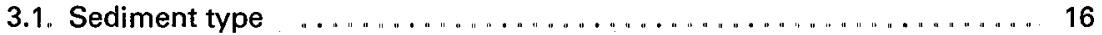

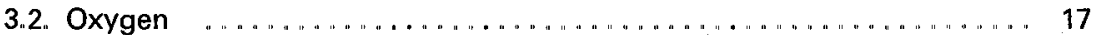

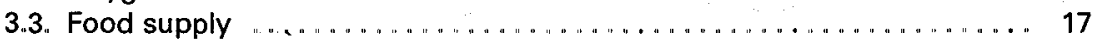

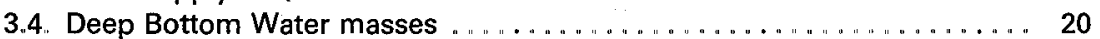

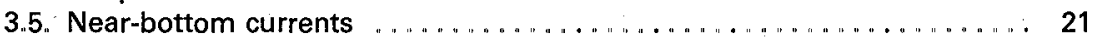

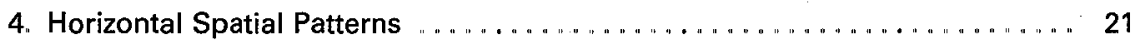

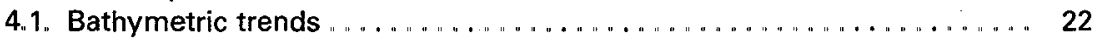

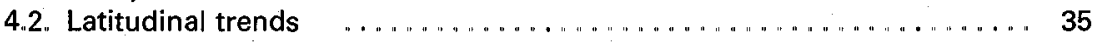

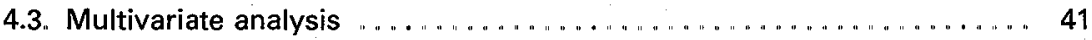

4.4. Comparison with other regions

4.5. Patterns at different taxonomic levels . . . . . . . . . . . . . . . . . 46

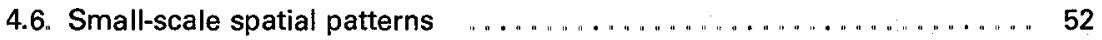

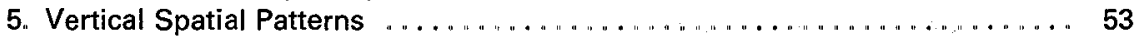

5.1. Suprabenthic microhabitats

5.2. Vertical distribution within the sediment . . . . . . 53 


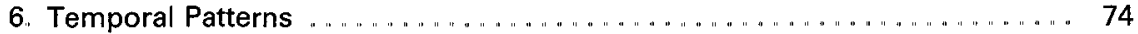

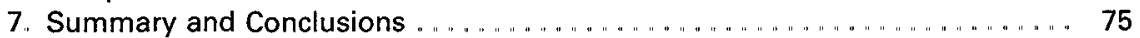

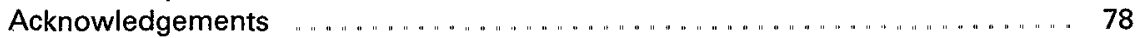

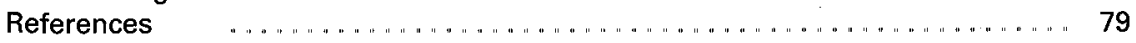

\section{INTRODUCTION}

Although the first ecological investigations on the meiobenthic communities of the deep northeast Atlantic were carried out 20 years ago (Thiel, 1972 b), it is only recently (1990) that co-operative research has been initiated by the European Community under the EC MAST I (Marine Science and Technology I 1990-1992) programme: "Natural variability and the prediction of change in marine benthic ecosystems". The general objectives of this EC programme, which continues in a MAST II project (1993-1996), are (i) to describe the natural structure and variability of offshore benthic populations in the northeast Atlantic, (ii) to relate the structure and variability to processes in the physical, chemical and biological environment, (iii) to describe the trophic network in the benthic boundary layer and to estimate the organic carbon flux through the deep-sea benthic ecosystem, and (iv) to attempt to predict the changes that are likely to be associated with natural and anthropogenic disturbance. An important component of benthic ecosystems, particularly in the deep sea (Thiel, 1975, 1983), is the meiobenthos, generally considered to include organisms in the size range $31-500 \mu \mathrm{m}$. The combined efforts of five laboratories in four of the countries participating in the MAST project have highlighted the gaps that exist in our knowledge of the meiobenthos of the northeast Atlantic and have prompted this review. Our main purpose is to summarize literature data and new results from an area lying between $15^{\circ} \mathrm{N}$ and $53^{\circ} \mathrm{N}$ and extending from the continental margin of western Europe and northwest Africa to the Mid-Atlantic Ridge (Figure 1).

Since the first quantitative investigation by Wigley and McIntyre (1964), data on deep-sea meiobenthos have been gathered from all oceans and attempts made to relate the broad geographical patterns observed to various environmental factors. On a planetary scale, one of the major environmental gradients is created by the slope of the ocean floor, a gradient which has important effects on benthic communities. As in the case of macrobenthos (Lampitt et al., 1986), the data available on meiobenthic densities in deep-sea environments also show trends which can be related to the amount and nature of organic matter reaching the seafloor (Thiel, 1983; Shirayama, 1983; Pfannkuche, 1985; Pfannkuche and Thiel, 1987). The distribution patterns of deep-sea organisms are 


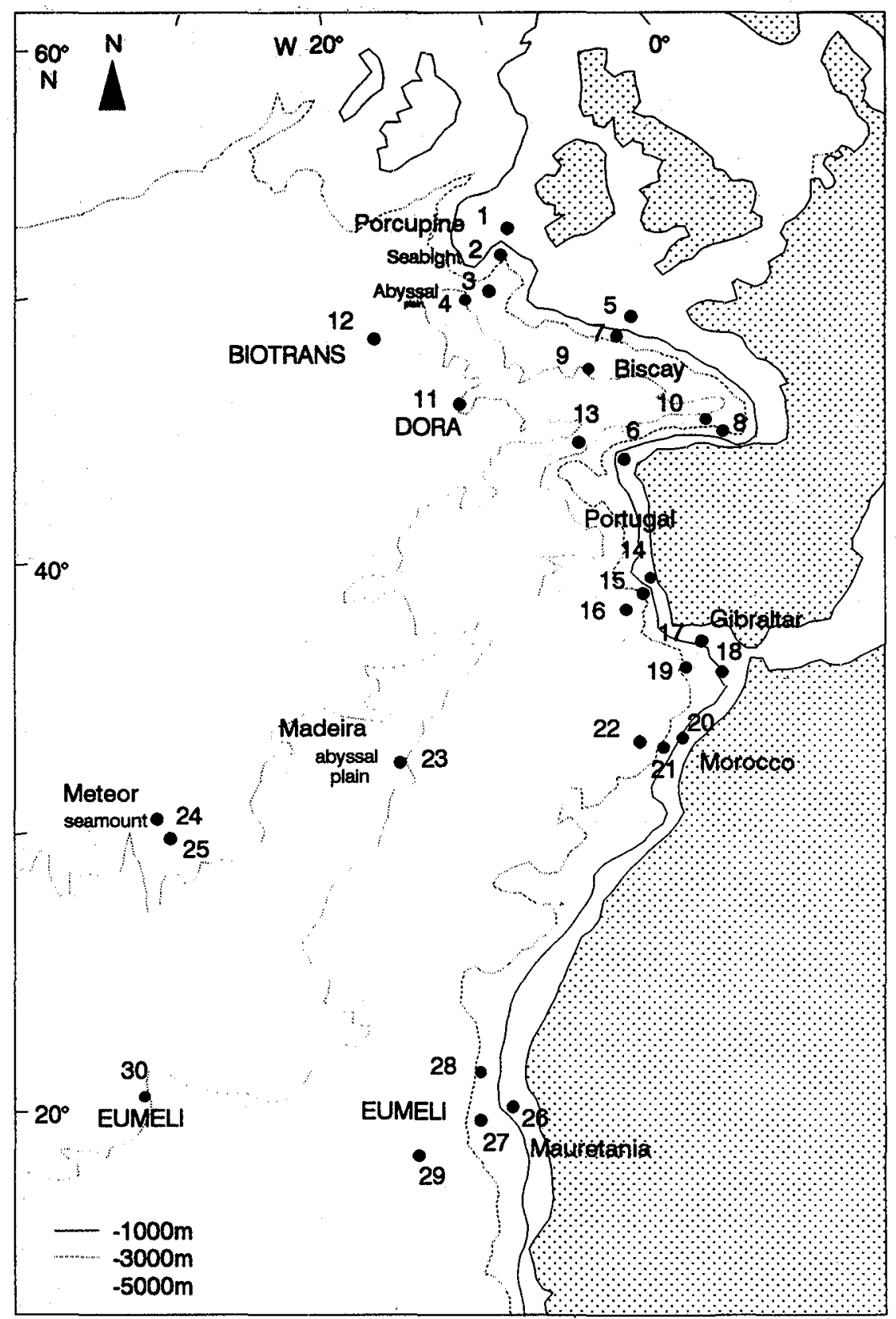

Figure 1 The northeast Atlantic showing the positions of the 30 sampling areas. 
influenced by other variables such as sediment type, bottom currents and bottom water masses. Local topographic and hydrodynamic features, such as canyons, seamounts and deep boundary currents, are also important. In addition, the ever-improving resolution of the physical structure of the deep sea, and technical advances in sampling gear and surface navigation, have permitted biologists to address small-scale variability, on scales ranging from centimetres to kilometres.

In this review we consider first the nature and scope of meiofaunal research in the northeast Atlantic and then discuss the environmental parameters which are believed to influence meiofaunal organisms. Next, we discuss the various types and scales of pattern observed among meiofaunal populations within our study area, progressing from the large-scale bathymetric and latitudinal trends and then to small-scale horizontal patterns within particular areas. Faunal densities and faunal composition are considered separately and compared with data from other regions. Finally, we discuss the distribution of meiofauna within sediment profiles and the temporal variability of populations. Our approach differs, therefore, from that adopted in Tietjen's (1992) recent review of deep-sea meiofauna which focused mainly on abundance and biomass data from different oceans and on the relationship between the biomass of the meiofauna and that of other faunal components.

\section{MEIOBENTHOS IN THE NORTHEAST ATLANTIC}

\subsection{Physiographic Setting}

The area under investigation consists of a series of deep basins separated by ridges. Basin depth tends to increase from north to south, with depths in excess of $5000 \mathrm{~m}$ occurring in basins to the west and northwest of the Cape Verde Islands.

A number of physiographic zones can be recognized within this region: continental shelf, continental slope, continental rise, abyssal apron and abyssal plain (Emery and Uchupi, 1984; see also Rona, 1980; Udintsev et al., 1989-1990). Secondary features include the zone of abyssal hills which separates the continental rise from the Mid-Atlantic Ridge and a number of major seamounts and volcanic islands. Notable aspects include the abyssal aprons (sediment masses deposited by geostrophic bottom currents) of the northwest African margin and around and to the west of the Rockall Trough (Hill, 1987) and the series of abyssal plains (from north to south the Porcupine, Biscay, Iberian, Tagus, Horseshoe, Seine, Madeira, Cape Verde, Gambia) which lie seaward of the continental rise. 
The area consists of different biogeochemical provinces of plankton productivity, such as upwelling (NW-Africa), trade wind regime, subtropical gyre, etc., which are of great consequence to the supply of food to the seabed and ultimately for the sediment type where pelagic sedimentation prevails.

\subsection{Historical Background}

The study of some meiobenthic taxa, particularly foraminifera, living in this region has a long history (e.g. Parker \& Jones, 1856; Brady, 1884). However, sampling for meiobenthos was incidental until the 1960s and 1970s when the first quantitative meiobenthic samples were collected from the German research vessel Meteor; numerical abundance data from these samples were published by Thiel $(1972 \mathrm{a}, \mathrm{b}, 1975,1978,1983)$ and Rachor (1975). Another quantitative investigation which included the meiobenthos was the BIOGAS programme, carried out during the 1970s in the Bay of Biscay (Dinet and Vivier, 1977; see also Dinet et al., 1985). More recent papers devoted partly or exclusively to the meiobenthos are those of Pfannkuche et al. (1990), Pfannkuche (1992, 1993b) in the BIOTRANS area and Rutgers van der Loeff and Lavaleye (1986) at the DORA site.

Other studies have focused on particular aspects of the meiobenthos. Some authors have considered just the nematodes (Riemann, 1974; Dinet and Vivier, 1979, 1981). Desbruyères et al. (1985) evaluated meiobenthic taxa as part of a recolonization experiment in the Bay of Biscay. Another approach has been to look for correlations between meiobenthic densities and environmental parameters such as bathymetric depth and the amount of organic matter in the sediment (Thiel, 1979b, 1983; Dinet and Khripounoff, 1980; Sibuet et al., 1989; Vanreusel et al., 1992). Although taxonomic studies of deep-sea meiobenthos are fairly rare in our area, some new taxa have been described among the harpacticoids (Bodin, 1968; Dinet 1977), nematodes (Decraemer, 1983), ostracods (Kornicker, 1989, van Harten, 1990) and tardigrades (Renaud-Mornant, 1989). Some of these investigations have dealt exclusively with the metazoans while others have included foraminifera within the scope of the meiobenthos. Several papers by Gooday (1986a, b, 1988), Gooday and Lambshead (1989), Lambshead and Gooday (1990) have described the foraminiferal meiobenthos in the northeast Atlantic. Gooday and Turley (1990) presented some additional data and Gooday (1990) established a new, ecologically important allogtomiid species. The numerous geologically orientated studies of modern deep-sea foraminifera in the northwest Atlantic (Murray, 1991) deal only with the hard-shelled taxa and are not considered further. 


\subsection{Sampling Areas}

Nine of the papers cited above provide data on the density and composition of metazoan and foraminiferal meiobenthos in the area under consideration and are further treated in a general data analysis (Thiel, 1972a, 1975; Dinet and Vivier, 1977; Pfannkuche et al., 1983, 1990; Pfannkuche, 1985, 1992; Rutgers van der Loeff and Lavaleye, 1986; Vanreusel et al., 1992). Information on foraminifera published by Gooday (1986a, b, 1988) and Gooday and Lambshead (1989) is not considered in the general approach because no total meiobenthic data are given in these articles. However, this information is discussed in the sections on foraminifera. For reasons explained below, we exclude the data of Rachor (1975) from this survey. Additional unpublished results are available from the Porcupine Seabight (Gooday, IOSDL benthic biology programme), Porcupine and Madeira Abyssal Plains (Gooday and Ferrero, IOSDL DEEPSEAS and EC MAST Programmes), Bay of Biscay (Vincx and Vanreusel, EC MAST programme), BIOTRANS site (Soltwedel and Gooday, BIOTRANS Programme) and from off northwest Africa (Dinet, EUMELI and EC MAST programmes).

In order to recognize general trends among the meiobenthos, we have grouped all the stations sampled during these published and unpublished studies into 30 areas (identified by number in Table 1) on the basis of geographical and bathymetric proximity. In what follows, density data and other relevant abiotic information on areas will always be an average value of the sampling stations situated within one of the 30 areas as defined in Table 1. References to area numbers in the following text refer always to one of the area numbers shown in Figure 1. Bathymetric proximity is arbitrarily defined with limits of following depth zones : $<1000 \mathrm{~m}, 1000-3000 \mathrm{~m}, 3000-4500 \mathrm{~m}$ and $>4500 \mathrm{~m}$. Inevitably, most of these areas are broader in their areal and bathymetric extent than the stations described in the original publications. Area locations and numbers are summarized in Figure 1. The original data from all sampling stations are summarized in Table 2.

\subsection{Collection and Processing}

Methods for the collection and processing of meiobenthic samples are discussed by Thiel (1983), Fleeger et al. (1988) and Pfannkuche and Thiel (1988). The data reviewed in the present chapter were obtained from samples collected with various kinds of coring devices (Table 1). A Reineck box corer was used in some of the early studies (Thiel, 1972b, 1975; Dinet and Vivier, 1977) but most investigators have used either an 
USNEL box corer or multiple corer (Hessler and Jumars, 1974; Barnett et al., 1984). Blomqvist (1991) has identified four factors which bias the sampling of soft bottom sediments, namely, the loss of superficial sediment, the distribution, resuspension and loss of enclosed sediments, core shortening, and repenetration. He urges extreme caution when evaluating results based on grab samples but considers box corers to be fairly reliable if used with a supporting stand and mechanism which secures the lids during retrieval through the water column. Blomqvist (1991) concludes that the Barnett Watson (SMBA) multiple corer (Barnett et al., 1984) "seems to be the best device for general sampling of open-sea, soft bottom sediments at present". It is equipped with a battery of up to 12 coring tubes and the penetration of these into the sediment is slowed by a hydraulic damping system. The multiple corer collects samples in which the sediment-water interface is virtually undisturbed; it is the only remotely operated coring device capable of reliably recovering phytodetritus. Sampling bias, within the data-set considered here, is investigated in detail in Bett et al. (1994).

Box core and multiple core samples have been subsampled in a variety of ways. Early German studies used a "meiostecher" with a cross-sectional area of $25 \mathrm{~cm}^{2}$ or $10 \mathrm{~cm}^{2}$ (Thiel, 1983). Dinet and Vivier (1977) and Rutgers van der Loeff and Lavaleye (1986) used transparent tubes with a cross-sectional area of 10 and $25 \mathrm{~cm}^{2}$ respectively. More recently, smaller subcores have been taken from both box and multiple corers using modified 20 or $50-\mathrm{ml}$ syringes $\left(3.46\right.$ and $5.31 \mathrm{~cm}^{2}$ across sectional area respectively). Some complete multiple corer samples have been sorted for metazoan and foraminiferal meiobenthos. Gooday and Lambshead (1989) and Lambshead and Gooday (1990) examined only the upper $1 \mathrm{~cm}$ of sediment for foraminifera analysis. However, most authors have followed the lead of Thiel (1966) by examining 1-cm thick sediment slices down to a depth of $4-7 \mathrm{~cm}$. Samples have generally been fixed and preserved using $4 \%$ formaldehyde, buffered with borax

Similar methods have been used to extract meiobenthos from the fixed samples (cf. Pfannkuche and Thiel, 1988). The sediment is passed through a sequence of sieves, the smallest mesh size used varying from 50 to $31 \mu \mathrm{m}$. The sieve residues are stained with Rose Bengal with added phenol and hand sorted under a binocular microscope. Rutgers van der Loeff and Lavaleye (1986) used elutriation to concentrate the meiobenthic organisms before sieving on a 50 - or $31-\mu \mathrm{m}$ mesh sieve. Rachor (1975) shook and decanted his samples at least eight times before preservation and sorting, a procedure which must account for the low densities of meiobenthos in his samples (Thiel, 1983). Because of these methodological difficulties, the data of Rachor (1975) are not included in our survey. In order to distinguish dead foraminiferal tests from those 
Table 1 Source data on meiofauna of the northeast Atlantic (nr, area number, cf. Figure 1; st, number of sampling stations per area; sa, total number of samples per area).

\begin{tabular}{|c|c|c|c|c|c|c|}
\hline $\mathrm{nr}$ & Author & Area of study & Depth (m) & st & sa & Corer \\
\hline \multirow[t]{2}{*}{1} & Gooday, unpubl. & Porcupine Seabight & 398 & 1 & 1 & Multi \\
\hline & Pfannkuche, 1985 & Porcupine Seabight & $500-960$ & 3 & 3 & Multi \\
\hline 2 & Pfannkuche, 1985 & Porcupine Seabight & $1492-2785$ & 4 & 4 & Multi \\
\hline \multirow[t]{2}{*}{3} & Gooday, unpubl. & Porcupine Seabight & $4090-4495$ & 2 & 2 & Multi \\
\hline & Pfannkuche, 1985 & Porcupine Seabight & $3567-4167$ & 2 & 2 & Multi \\
\hline 4 & Pfannkuche, 1985 & Porcupine Abyssal plain & $4500-4850$ & 2 & 2 & Multi \\
\hline 5 & Vanreusel and Vincx, unpubl. & Bay of Biscay $N$ & $70-170$ & 3 & 6 & Box \\
\hline 6 & Vanreusel et al., 1992 & Bay of Biscay $\mathrm{S}$ & $190-325$ & 2 & 4 & Box \\
\hline 7 & Dinet and Vivier, 1977 & Bay of Biscay $\mathrm{N}$ & $2035-3370$ & 20 & 20 & Reineck \\
\hline 8 & Dinet and Vivier, 1977 & Bay of Biscay $S$ & $1912-2480$ & 7 & 7 & Reineck \\
\hline 9 & Dinet and Vivier, 1977 & Bay of Biscay $\mathrm{N}$ & $4097-4725$ & 12 & 12 & Reineck \\
\hline
\end{tabular}


Gooday, unpubl.

BIOTRANS

4560

Pfannkuche et al., 1990

BIOTRANS

4550

Thiel, 1972a

Iberic sea

$5272-5340$

Thiel, $1975^{b}$

Thiel, $1975^{b}$

Thiel, $1975^{b}$

Thiel, $1975^{b}$

Pfannkuche et al., $1983^{b}$

Pfannkuche et al., $1983^{b}$

Portugal

250-1250

Portugal

$1250-2250$

Portugal

$3250-5250$

Gibraltar

250-1250

NW Africa

131-818

NW Africa

1163-3093

Morocco

$250-1250$

Thiel, $1975^{b}$

Thiel, $1975^{b}$

Morocco

$1250-2250$

Morocco

Madeira Abyssal plain

Gooday, unpubl.

Madeira Abyssal plain

$4250-4750$

$4856-5120$

4856

$$
\text { unpubl. }{ }^{a}
$$

24 Thiel, $1975^{b}$

Thiel, $1975^{b}$

Great Meteor seamount

250-750

Great Meteor seamount

$1250-1750$

190-1250

Thiel, $1975^{b}$

Mauretania

1750-3250

Dinet, unpubl.

Mauretania

1543-2041

Dinet, unpubl.

Eumeli

Eumeli

3107-3137

Dinet, unpubl.

Eumeli

$4568-4652$

${ }^{a}$ Only nematode densities available.

${ }^{b}$ Only total metazoan meiofauna densities available. 
Table 2 Meiofaunal densities for samples collected in the northeast Atlantic (ar.nr, area number; Nem, Nematoda; Cop, harpacticoid copepods + nauplii; Turb, Turbellaria; Pol, Polychaeta; Oli, Oligochaeta; Ostr, Ostracoda; Hydr, Hydrozoa; Gas, Gastrotricha; Tar, Tardigrada; Kin, Kinorhyncha; Amp, Amphipoda; Hal, Halacaroidea; Lor, Loricifera; Iso, Isopoda; Biv, Bivalvia; Tan, Tanaidacea; Fora, Foraminifera; Meio, total meiofauna; Metaz, metazoan meiofauna).

\begin{tabular}{|c|c|c|c|c|c|c|c|c|c|c|c|}
\hline Author & Area & ar. nr & Depth $(\mathrm{m})$ & Sample & Nem & Cop & Turb & Pol & Oli & Ostr & Hydr \\
\hline $\begin{array}{l}\text { Dinet, } \\
\text { unpubl. }\end{array}$ & Eumeli & $\begin{array}{l}28 \\
28 \\
28 \\
28 \\
28 \\
28 \\
28 \\
28 \\
28 \\
28 \\
28 \\
28 \\
29 \\
29 \\
29 \\
29 \\
29 \\
29 \\
29 \\
29 \\
29 \\
29 \\
29 \\
29 \\
29 \\
29 \\
29 \\
29 \\
29 \\
29 \\
30 \\
30 \\
30 \\
30 \\
30 \\
30 \\
30 \\
30 \\
30 \\
30 \\
30 \\
30 \\
30 \\
30 \\
30 \\
30\end{array}$ & $\begin{array}{l}1970 \\
1543 \\
1590 \\
2041 \\
1970 \\
1618 \\
3120 \\
3137 \\
3136 \\
3124 \\
3107 \\
3118 \\
3130 \\
3128 \\
3118 \\
4629 \\
4582 \\
4590 \\
4582 \\
4568 \\
4580 \\
4652 \\
4569\end{array}$ & $\begin{array}{r}\text { KGS44 a } \\
\text { b } \\
\text { KGS38 a } \\
\text { b } \\
\text { KGS41 a } \\
\text { b } \\
\text { KGS43 a } \\
\text { b } \\
\text { KGS45 a } \\
\text { b } \\
\text { KGS39 a } \\
\text { b } \\
\text { KGS10 a } \\
\text { b } \\
\text { KGS13 a } \\
\text { b } \\
\text { KGS14 a } \\
\text { b } \\
\text { KGS11 a } \\
\text { b } \\
\text { KGS12 a } \\
\text { b } \\
\text { KGS18 a } \\
\text { b } \\
\text { KGS15 a } \\
\text { b } \\
\text { KGS16 a } \\
\text { KG } \\
\text { KGS21 a } \\
\text { KGS02 a } \\
\text { KGS06 a } \\
\text { KGS03 a } \\
\text { KG } \\
\text { KGS09 a } \\
\text { KGS04 a } \\
\text { KGS05 a } \\
\text { bGS07 a } \\
\text { b } \\
\text { b }\end{array}$ & $\begin{array}{r}4765 \\
2561 \\
8493 \\
764.6 \\
1235.4 \\
1033.9 \\
1182.7 \\
1367.2 \\
862.5 \\
779.7 \\
13898 \\
11337 \\
3333 \\
3371 \\
2561 \\
421.8 \\
474.6 \\
655.4 \\
455.7 \\
559.3 \\
5518 \\
4482 \\
5725 \\
5405 \\
7458 \\
4765 \\
11224 \\
5876 \\
201.5 \\
113.0 \\
167.6 \\
1544 \\
1205 \\
99.8 \\
1318 \\
2863 \\
960 \\
1525 \\
490 \\
810 \\
96.0 \\
105.5 \\
64.0 \\
113.0 \\
60.3 \\
111.1\end{array}$ & $\begin{array}{r}9.4 \\
30.1 \\
979 \\
584 \\
716 \\
75.3 \\
471 \\
94.2 \\
169 \\
30.1 \\
37.7 \\
264 \\
16.9 \\
301 \\
301 \\
169 \\
43.3 \\
32.0 \\
33.9 \\
16.9 \\
13.2 \\
11.3 \\
132 \\
113 \\
339 \\
339 \\
207 \\
245 \\
94 \\
245 \\
00 \\
5.6 \\
19 \\
11.3 \\
0.0 \\
5.6 \\
132 \\
19 \\
56 \\
75 \\
56 \\
75 \\
139 \\
16.9 \\
7.5\end{array}$ & & $\begin{array}{rl}18 & 8 \\
28 & 2 \\
1 & 9 \\
24.5 \\
45.2 \\
132 \\
18.8 \\
320 \\
13.2 \\
56 \\
339 \\
15.1 \\
7.5 \\
11.3 \\
207 \\
5.6 \\
151 \\
11.3 \\
3.8 \\
13.2 \\
339 \\
13.2 \\
11.3 \\
9.4 \\
132 \\
3.8 \\
188 \\
151 \\
38 \\
38 \\
3.8 \\
1.9 \\
19 \\
0.0 \\
7.5 \\
199 \\
38 \\
38 \\
38 \\
38 \\
00 \\
0.0 \\
0.0 \\
00 \\
0.0 \\
0.0\end{array}$ & , & 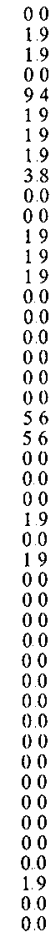 & \\
\hline $\begin{array}{l}\text { Ferrero, } \\
\text { unpubl }\end{array}$ & $\begin{array}{c}\text { Porcupine } \\
\text { Abyssal } \\
\text { Plain }\end{array}$ & $\begin{array}{l}4 \\
4 \\
4 \\
4 \\
4 \\
4\end{array}$ & 4850 & $\begin{array}{r}16(5) \\
41(1) \\
5(11) \\
24(7) \\
26(10) \\
26(11)\end{array}$ & $\begin{array}{l}3310 \\
220.9 \\
374.0 \\
285.7 \\
603.2 \\
516.6\end{array}$ & & & & & & \\
\hline $\begin{array}{l}\text { Gooday, } \\
\text { unpubl. }\end{array}$ & $\begin{array}{l}\text { Porcupine } \\
\text { Seabight }\end{array}$ & $\begin{array}{l}1 \\
2 \\
2 \\
3 \\
3\end{array}$ & $\begin{array}{r}398 \\
1340 \\
1340 \\
4090 \\
4495\end{array}$ & $\begin{array}{l}51620 \\
51502 \\
51615 \\
51504 \\
51606\end{array}$ & $\begin{array}{r}6955 \\
12110 \\
1026.0 \\
215.6 \\
372.8\end{array}$ & $\begin{array}{r}840 \\
118.0 \\
162.0 \\
38.0 \\
29.0\end{array}$ & $\begin{array}{ll}0 & 0 \\
0.0 & 0 \\
0 & 0 \\
0 & 0 \\
0 & 0\end{array}$ & $\begin{array}{r}0.0 \\
11.8 \\
75 \\
3.6 \\
29\end{array}$ & $\begin{array}{ll}0 & 0 \\
0 & 0 \\
0 & 0 \\
0 & 0 \\
0 & 0\end{array}$ & $\begin{array}{r}116 \\
15.0 \\
46 \\
0.7 \\
3.0\end{array}$ & $\begin{array}{ll}0.0 \\
0.0 \\
0.0 \\
0 & 0 \\
0 & 0\end{array}$ \\
\hline $\begin{array}{l}\text { Gooday, } \\
\text { unpubl } \\
\text { Ferrero, } \\
\text { unpubl. } \\
\text { Soltwedel, } \\
\text { unpubl. }\end{array}$ & $\begin{array}{c}\text { Madeira } \\
\text { Abyssal } \\
\text { Plain }\end{array}$ & $\begin{array}{l}23 \\
23 \\
23 \\
23 \\
23 \\
23 \\
23 \\
23\end{array}$ & $\begin{array}{r}5120 \\
4856 \\
4856 \\
4856-4950\end{array}$ & $\begin{array}{r}354 \\
12174(88) \\
12174(93) \\
12174(94) \\
12174(88) \\
12174(24) \\
12174(26) \\
12174(86)\end{array}$ & $\begin{array}{r}40.5 \\
179.6 \\
79.5 \\
106.9 \\
59.9 \\
690 \\
550 \\
430\end{array}$ & $\begin{array}{r}13 \\
19.0\end{array}$ & $\begin{array}{ll}0 & 0 \\
0 & 0\end{array}$ & $\begin{array}{l}0.0 \\
24\end{array}$ & $\begin{array}{l}0.0 \\
0.0\end{array}$ & $\begin{array}{l}0.0 \\
0.4\end{array}$ & $\begin{array}{ll}0 & 0 \\
0 & 0\end{array}$ \\
\hline $\begin{array}{l}\text { Vanreusel } \\
\text { and Vincx, } \\
\text { unpubi. } \\
\text { Vanreusel } \\
\text { et al., } 1992\end{array}$ & $\begin{array}{l}\text { Bay of } \\
\text { Biscay }\end{array}$ & $\begin{array}{l}5 \\
5 \\
5 \\
5 \\
5 \\
5 \\
6 \\
6 \\
6 \\
6\end{array}$ & $\begin{array}{r}70 \\
170 \\
148 \\
123 \\
300\end{array}$ & $\begin{array}{r}1 a \\
1 b \\
3 a \\
3 b \\
\$ 11 a \\
511 b \\
6 a \\
6 b \\
8 a \\
8 b\end{array}$ & $\begin{array}{r}8090 \\
658.0 \\
193.0 \\
172.0 \\
255.0 \\
171.0 \\
1031.0 \\
7730 \\
4190 \\
4790\end{array}$ & $\begin{array}{r}166.0 \\
72.0 \\
66.0 \\
34.0 \\
145.0 \\
64.0 \\
450 \\
460 \\
300 \\
150\end{array}$ & $\begin{array}{r}49.0 \\
48.0 \\
73.0 \\
188.0 \\
10.0 \\
24.0 \\
10.0 \\
320 \\
4.0 \\
0.0\end{array}$ & $\begin{array}{r}350 \\
250 \\
200 \\
13.0 \\
27.0 \\
29.0 \\
18.0 \\
21.0 \\
100 \\
9.0\end{array}$ & $\begin{array}{ll}9 & 0 \\
5 & 0 \\
0 & 0 \\
1 & 0 \\
0 & 0 \\
0 & 0 \\
0 & 0 \\
0.0 \\
0 & 0 \\
0 & 0\end{array}$ & $\begin{array}{r}70 \\
20 \\
140 \\
00 \\
20.0 \\
80 \\
2.0 \\
3.0 \\
0.0 \\
0.0\end{array}$ & $\begin{array}{ll}7 & 0 \\
4 & 0 \\
3 & 0 \\
1 & 0 \\
3 & 0 \\
2 & 0 \\
0 & 0 \\
0 & 0 \\
0 & 0 \\
0 & 0\end{array}$ \\
\hline
\end{tabular}




\begin{tabular}{|c|c|c|c|c|c|c|c|c|c|c|c|c|c|c|}
\hline Gas & Iar & Kin & Amp & $\mathrm{Hal}$ & Lor & Iso & Biv & $\operatorname{Tan}$ & Others & Fora & Meio & Metaz & $\underset{(\%)}{\mathrm{Nem}}$ & $\begin{array}{l}\text { Cop } \\
(\%)\end{array}$ \\
\hline & 00 & 00 & & & & & 00 & 0.0 & 00 & & & 5047 & 94.4 & 1.9 \\
\hline & 00 & 19 & & & & & 00 & 38 & 3.8 & & & 325.8 & 786 & 92 \\
\hline & 00 & 38 & & & & & 38 & 0.0 & 5.6 & & & 9642 & 88.1 & 102 \\
\hline & 00 & 38 & & & & & 00 & 0.0 & 7.5 & & & 858.8 & 89.0 & 68 \\
\hline & 00 & 7.5 & & & & & 00 & 0.0 & 0.0 & & & 1369.1 & 90.2 & 52 \\
\hline & 00 & 19 & & & & & 00 & 19 & 0.0 & & & 11281 & 91.7 & 67 \\
\hline & 00 & 38 & & & & & 00 & 00 & 0.0 & & & 1254.2 & 943 & 38 \\
\hline & 00 & 56 & & & & & 00 & 00 & 1.9 & & & 1502.8 & 910 & 63 \\
\hline & 00 & 56 & & & & & 00 & 00 & 19 & & & 904.0 & 954 & 19 \\
\hline & 00 & 19 & & & & & 00 & 00 & 0.0 & & & 817.3 & 954 & 37 \\
\hline & 00 & 3.8 & & & & & 00 & 00 & 19 & & & 1467.0 & 947 & 26 \\
\hline & 00 & 00 & & & & & 00 & 00 & 0.0 & & & 1177.0 & 963 & 22 \\
\hline & 00 & 00 & & & & & 00 & 00 & 19 & & & 361.6 & 922 & 47 \\
\hline & 00 & 00 & & & & & 19 & 00 & 0.0 & & & 382.3 & 882 & 7.9 \\
\hline & 19 & 00 & & & & & 19 & 00 & 0.0 & & & 310.7 & 824 & 9.7 \\
\hline & 00 & 00 & & & & & 00 & 00 & 0.0 & & & 4444 & 949 & 3.8 \\
\hline & 00 & 19 & & & & & 0.0 & 00 & 0.0 & & & 5348 & 887 & 81 \\
\hline & 00 & 00 & & & & & 19 & 00 & 0.0 & & & 7006 & 935 & 46 \\
\hline & 00 & 00 & & & & & 00 & 00 & 00 & & & 4934 & 924 & 6.9 \\
\hline & 00 & 00 & & & & & 00 & 00 & 19 & & & 5913 & 946 & 2.9 \\
\hline & 00 & 00 & & & & & 19 & 00 & 0.0 & & & 6064 & 910 & 2.2 \\
\hline & 00 & 1.9 & & & & & 00 & 00 & 19 & & & 4821 & 930 & 2.3 \\
\hline & 00 & 00 & & & & & 0.0 & 00 & 00 & & & 5970 & 959 & 2.2 \\
\hline & 00 & 00 & & & & & 0.0 & 00 & 19 & & & 5631 & 960 & 20 \\
\hline & 00 & 0.0 & & & & & 0.0 & 00 & 00 & & & 7928 & 941 & 4.3 \\
\hline & 19 & 0.0 & & & & & 0.0 & 38 & 00 & & & 5217 & 913 & 65 \\
\hline & 00 & 0.0 & & & & & 0.0 & 00 & 00 & & & 1162.0 & 966 & 18 \\
\hline & 00 & 0.0 & & & & & 0.0 & 00 & 00 & & & 6290 & 934 & 39 \\
\hline & 00 & 0.0 & & & & & 00 & 0.0 & 00 & & & 214.7 & 939 & 44 \\
\hline & 00 & 0.0 & & & & & 00 & 00 & 00 & & & 1412 & 80.0 & 173 \\
\hline & 19 & 0.0 & & & & & 00 & 0.0 & 00 & & & 173.3 & 967 & 00 \\
\hline & 00 & 1.9 & & & & & 00 & 0.0 & 00 & & & 163.8 & 943 & 34 \\
\hline & 00 & 00 & & & & & 00 & 0.0 & 00 & & & 124.3 & 970 & 15 \\
\hline & 00 & 0.0 & & & & & 00 & 0.0 & 00 & & & 111.1 & 898 & 102 \\
\hline & 00 & 0.0 & & & & & 00 & 0.0 & 00 & & & 1394 & 946 & 00 \\
\hline & 00 & $\begin{array}{l}0.0 \\
19\end{array}$ & & & & & 00 & 0.0 & 0.0 & & & 2957 & 968 & 19 \\
\hline & 00 & 00 & & & & & 00 & 19 & 0.0 & & & 1149 & 836 & 115 \\
\hline & 00 & 19 & & & & & 00 & 00 & 0.0 & & & 1601 & 953 & 12 \\
\hline & 00 & 0.0 & & & & & 00 & 00 & 0.0 & & & 584 & 839 & 9.7 \\
\hline & 00 & 0.0 & & & & & 00 & 00 & 0.0 & & & 923 & 878 & 8.2 \\
\hline & 00 & 00 & & & & & 0.0 & 00 & 0.0 & & & 1017 & 944 & 5.6 \\
\hline & 00 & 00 & & & & & 00 & 00 & 0.0 & & & 1130 & 933 & 6.7 \\
\hline & 00 & 00 & & & & & 0.0 & 00 & 0.0 & & & 659 & 97.1 & 2.9 \\
\hline & 00 & 00 & & & & & 0.0 & 00 & 0.0 & & & 1186 & 95.2 & 32 \\
\hline & 00 & 00 & & & & & 00 & 00 & 0.0 & & & 772 & 780 & 220 \\
\hline & 00 & 00 & & & & & 00 & 00 & 0.0 & & & 1186 & 937 & 63 \\
\hline
\end{tabular}

\begin{tabular}{|c|c|c|c|c|c|c|c|c|c|c|c|c|c|c|}
\hline 0.0 & 00 & 0.0 & 0.0 & 00 & 00 & 00 & 00 & 00 & 0.0 & 10983 & 18903 & 792.1 & 879 & 106 \\
\hline 0.0 & 49 & 4.9 & 0.0 & 00 & 00 & 00 & 38 & 0.0 & 9.0 & 18352 & 32136 & 1378.4 & 879 & 86 \\
\hline 0.0 & 92 & 3.8 & 0.0 & 00 & 00 & 00 & 17 & 0.0 & 92 & 20607 & 32848 & 12241 & 838 & 132 \\
\hline 00 & 01 & 07 & 0.0 & 00 & 00 & 00 & 01 & 0.0 & 00 & & 2589 & 2589 & 833 & 147 \\
\hline 00 & 00 & 30 & 0.0 & 00 & 0.0 & 00 & 30 & 00 & 30 & 9563 & 13730 & 4167 & 895 & \\
\hline 0.0 & 00 & 0.0 & 0.0 & 00 & 0.0 & 00 & 00 & 0.0 & 0.0 & 344 & 762 & 418 & 96.9 & \\
\hline 0.0 & 00 & 0.8 & 0.0 & 00 & 0.0 & 04 & 00 & 00 & 0.0 & 234.0 & 4366 & 2026 & 886 & \\
\hline
\end{tabular}

$\begin{array}{rrrrrr}24.0 & 140 & 00 & 0.0 & 00 & 0.0 \\ 5.0 & 4.0 & 0.0 & 0.0 & 0.0 & 0.0 \\ 5.0 & 0.0 & 0.0 & 0.0 & 0.0 & 0.0 \\ 0.0 & 1.0 & 00 & 7.0 & 1.0 & 0.0 \\ 8.0 & 2.0 & 00 & 0.0 & 0.0 & 0.0 \\ 1.0 & 2.0 & 10 & 0.0 & 2.0 & 0.0 \\ 0.0 & 0.0 & 60 & 00 & 0.0 & 0.0 \\ 0.0 & 10 & 40 & 0.0 & 00 & 0.0 \\ 0.0 & 00 & 00 & 00 & 00 & 0.0 \\ 0.0 & 0.0 & 00 & 00 & 00 & 00\end{array}$

$\begin{array}{llll}00 & 0.0 & 0.0 & 00 \\ 0.0 & 0.0 & 0.0 & 00 \\ 0.0 & 0.0 & 0.0 & 00 \\ 0.0 & 0.0 & 0.0 & 0.0 \\ 0.0 & 0.0 & 0.0 & 0.0 \\ 0.0 & 0.0 & 0.0 & 0.0 \\ 0.0 & 0.0 & 0.0 & 0.0 \\ 00 & 0.0 & 0.0 & 0.0 \\ 00 & 0.0 & 0.0 & 0.0 \\ 0.0 & 0.0 & 0.0 & 0.0\end{array}$

$\begin{array}{rrr}1120.0 & 722 & 14.8 \\ 823.0 & 800 & 8.7 \\ 374.0 & 516 & 176 \\ 4180 & 41.1 & 81 \\ 4700 & 54.3 & 309 \\ 3040 & 56.3 & 21.1 \\ 11120 & 92.7 & 40 \\ 8800 & 87.8 & 52 \\ 4630 & 90.5 & 6.5 \\ 5030 & 95.2 & 3.0\end{array}$




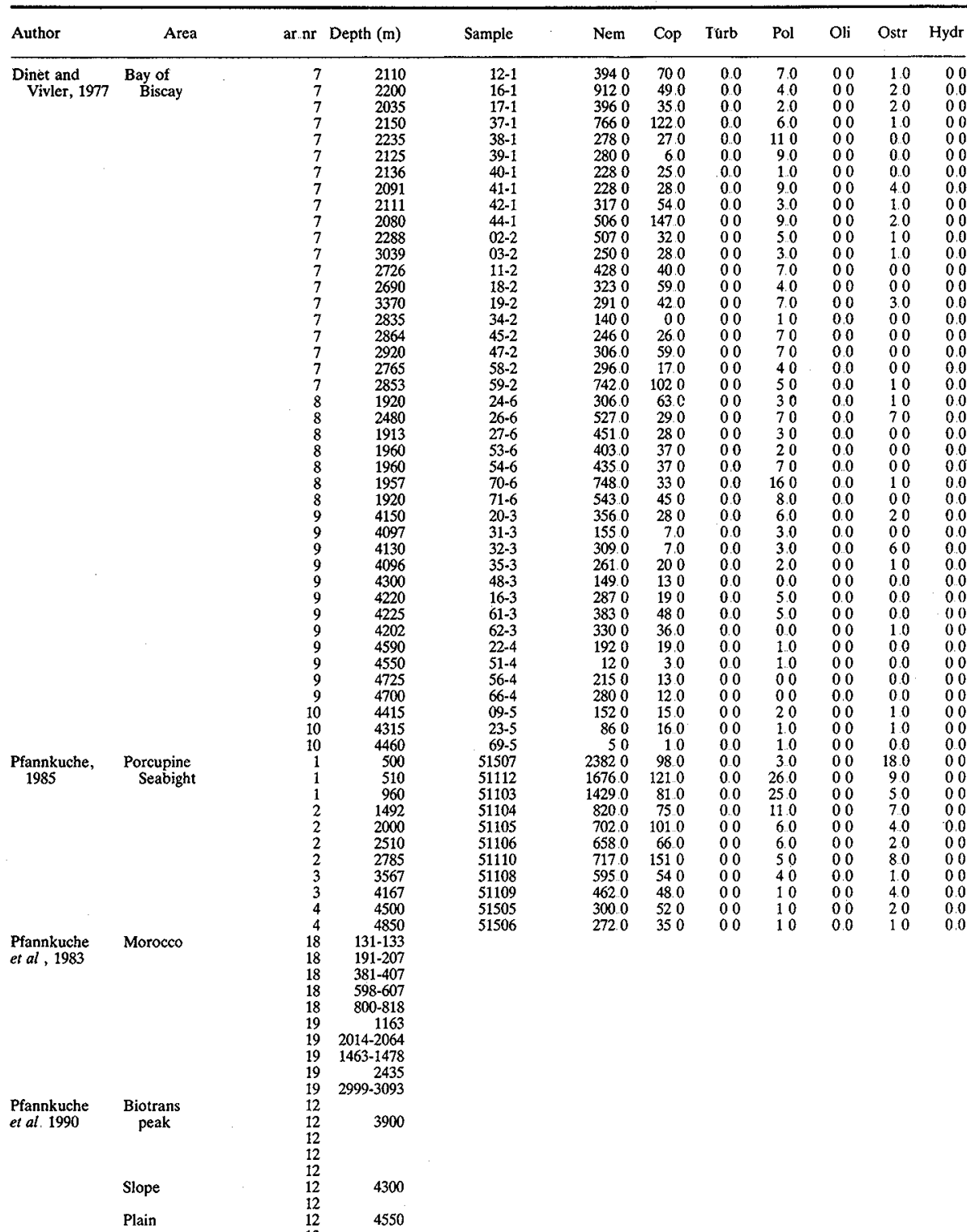




\begin{tabular}{|c|c|c|c|c|c|c|c|c|c|c|c|c|}
\hline Gas & Tar & $\mathrm{Kin}$ & Amp & $\mathrm{Hal}$ & Lor & Iso & Biv & Tan & Others & Fora & Meio & Metaz \\
\hline 00 & 10 & 10 & 0.0 & 10 & 0.0 & 00 & 00 & 00 & 10 & & & 478.0 \\
\hline 00 & 2.0 & 20 & 0.0 & 10 & 0.0 & 00 & 00 & 20 & 40 & & & 9780 \\
\hline 00 & 20 & 10 & 00 & 0.0 & 0.0 & 10 & 0.0 & 00 & 1.0 & & & 4400 \\
\hline 0.0 & 4.0 & 20 & 00 & 0.0 & 0.0 & 0.0 & 00 & 00 & 50 & & & 907.0 \\
\hline 0.0 & 2.0 & 00 & 00 & 0.0 & 0.0 & 0.0 & 0.0 & 00 & 0.0 & & & 320.0 \\
\hline 00 & 00 & 00 & 00 & 0.0 & 0.0 & 1.0 & 00 & 00 & 8.0 & & & 3040 \\
\hline 0.0 & 30 & 00 & 00 & 0.0 & 0.0 & 0.0 & 0.0 & 00 & 00 & & & 2570 \\
\hline 0.0 & 00 & 1.0 & 00 & 00 & 0.0 & 00 & 0.0 & 00 & 00 & & & 2700 \\
\hline 0.0 & 20 & 0.0 & 00 & 00 & 0.0 & 0.0 & 0.0 & 00 & 30 & & & 3800 \\
\hline 0.0 & 20 & 30 & 00 & 00 & 00 & 20 & 0.0 & 00 & 00 & & & 671.0 \\
\hline 00 & 0.0 & 10 & 00 & 10 & 00 & 10 & 00 & 0.0 & 1.0 & & & 549.0 \\
\hline 00 & 20 & 10 & 00 & I 0 & 00 & 00 & 0.0 & 0.0 & 2.0 & & & 288.0 \\
\hline 00 & 10 & 10 & 00 & 10 & 00 & 00 & 0.0 & 1.0 & 3.0 & & & 536.0 \\
\hline 00 & 00 & 10 & 0.0 & 00 & 00 & 00 & 00 & 0.0 & 0.0 & & & 387.0 \\
\hline 00 & 00 & 10 & 0.0 & 10 & 00 & 10 & 00 & 0.0 & 0.0 & & & 346.0 \\
\hline 00 & 00 & 00 & 0.0 & 10 & 00 & 00 & 00 & 0.0 & 0.0 & & & 1420 \\
\hline 00 & 10 & 00 & 0.0 & 00 & 0.0 & 00 & 00 & 0.0 & 0.0 & & & 2810 \\
\hline 00 & 00 & 10 & 0.0 & 00 & 0.0 & 00 & 00 & 1.0 & 0.0 & & & 3740 \\
\hline 00 & 00 & 00 & 00 & 00 & 0.0 & 00 & 00 & 00 & 0.0 & & & 3150 \\
\hline 00 & 00 & 30 & 0.0 & 00 & 0.0 & 00 & 00 & 0.0 & 00 & & . & 8530 \\
\hline 00 & 10 & 10 & 00 & 00 & 00 & 10 & 0.0 & 00 & 30 & & & 3790 \\
\hline 00 & 0.0 & 2.0 & 0.0 & 00 & 0.0 & 0.0 & 00 & 00 & 70 & & & 579.0 \\
\hline 00 & 0.0 & 0.0 & 00 & 0.0 & 00 & 0.0 & 0.0 & 00 & 00 & & & 482.0 \\
\hline 00 & 0.0 & 10 & 00 & 0.0 & 00 & 0.0 & 0.0 & 00 & 0.0 & & & 445.0 \\
\hline 00 & 0.0 & 2.0 & 00 & 0.0 & 00 & 0.0 & 0.0 & 10 & 1.0 & & & 483.0 \\
\hline 00 & 1.0 & 5.0 & 00 & 0.0 & 00 & 0.0 & 0.0 & 0.0 & 1.0 & & & 8080 \\
\hline 0.0 & 40 & 1.0 & 00 & 00 & 00 & 00 & 0.0 & 00 & 10 & & & 6030 \\
\hline 0.0 & 0.0 & 10 & 00 & 10 & 00 & 00 & 10 & 0.0 & 00 & & & 395.0 \\
\hline 0.0 & 0.0 & 0.0 & 00 & 00 & 00 & 00 & 00 & 0.0 & 00 & & & 165.0 \\
\hline 0.0 & 00 & 00 & 00 & 00 & 00 & 00 & 00 & 0.0 & 0.0 & & & 3200 \\
\hline 0.0 & 0.0 & 10 & 0.0 & 00 & 00 & 00 & 00 & 0.0 & 20 & & & 2870 \\
\hline 0.0 & 0.0 & 00 & 00 & 00 & 00 & 00 & 00 & 00 & 00 & & & 620 \\
\hline 0.0 & 0.0 & 00 & 00 & 00 & 00 & 00 & 00 & 00 & 00 & & & 3110 \\
\hline 0.0 & 00 & 10 & 0.0 & 0.0 & 0.0 & 00 & 00 & 00 & 00 & & & 4370 \\
\hline 0.0 & 00 & 20 & 00 & 00 & 0.0 & 00 & 00 & 00 & 00 & & & 369.0 \\
\hline 0.0 & 00 & 00 & 00 & 0.0 & 0.0 & 10 & 0.0 & 00 & 00 & & & 213.0 \\
\hline 0.0 & 00 & 00 & 0.0 & 0.0 & 0.0 & 0.0 & 0.0 & 00 & 0.0 & & & 160 \\
\hline 0.0 & 00 & 10 & 00 & 0.0 & 0.0 & 0.0 & 0.0 & 00 & 1.0 & & & 2300 \\
\hline 0.0 & 00 & 0.0 & 0.0 & 00 & 0.0 & 0.0 & 0.0 & 00 & 1.0 & & & 297.0 \\
\hline 00 & 0.0 & 0.0 & 00 & 0.0 & 0.0 & 1.0 & 0.0 & 0.0 & 0.0 & & & 1710 \\
\hline 00 & 0.0 & 0.0 & 00 & 0.0 & 00 & 1.0 & 0.0 & 0.0 & 0.0 & & & 1050 \\
\hline 00 & 0.0 & 0.0 & 00 & 0.0 & 0.0 & 00 & 0.0 & 0.0 & 00 & & & 7.0 \\
\hline 200 & 00 & 80 & 0.0 & 20 & 00 & 00 & 620 & 0.0 & 10 & & & 26040 \\
\hline 810 & 0.0 & 60 & 00 & 30 & 00 & 0.0 & 12.0 & 0.0 & 290 & & & 1963.0 \\
\hline 330 & 3.0 & 40 & 00 & 30 & 00 & 00 & 8.0 & 0.0 & 20 & & & 1593.0 \\
\hline 8.0 & 3.0 & 2.0 & 00 & 70 & 00 & 00 & 40 & 0.0 & 50 & & & 943.0 \\
\hline 7.0 & 0.0 & 4.0 & 00 & 10 & 00 & 00 & 10 & 00 & 20 & & & 8280 \\
\hline 5.0 & 10 & 1.0 & 00 & 10 & 00 & 00 & 10 & 00 & 30 & & & 744.0 \\
\hline 120 & 00 & 5.0 & 00 & 80 & 0.0 & 00 & 00 & 00 & 10 & & & 9000 \\
\hline 70 & 00 & 0.0 & 00 & 00 & 0.0 & 00 & 00 & 00 & 20 & & & 663.0 \\
\hline 40 & 00 & 2.0 & 00 & 50 & 0.0 & 00 & 10 & 00 & 10 & & & 5280 \\
\hline 40 & 00 & 20 & 0.0 & 00 & 0.0 & 00 & 00 & 00 & 10 & & & 3620 \\
\hline 40 & 10 & 0.0 & 00 & 10 & 00 & 00 & 0.0 & 00 & 1.0 & & & 3150 \\
\hline & & & & & & & & & & & & $\begin{array}{l}26560 \\
17780\end{array}$ \\
\hline & & & & & & & & & & & & $\begin{array}{l}17780 \\
24800\end{array}$ \\
\hline & & & & & & & & & & & & 14650 \\
\hline & & & & & & & & & & & & 11750 \\
\hline & & & & & & & & & & & & 6310 \\
\hline & & & & & & & & & & & & 5700 \\
\hline & & & & & & & & & & & & 6200 \\
\hline & & & & & & & & & & & & 550.0 \\
\hline & & & & & & & & & & & & 557.0 \\
\hline & & & & & & & & & & & & 364.0 \\
\hline & & & & & & & & & & & & $\begin{array}{l}376.0 \\
3520\end{array}$ \\
\hline & & & & & & & & & & & & $\begin{array}{l}352.0 \\
308.0\end{array}$ \\
\hline & & & & & & & & & & & & 3860 \\
\hline & & & & & & & & & & & & 302.0 \\
\hline & & & & & & & & & & & & 302.0 \\
\hline & & & & & & & & & & & & 316.0 \\
\hline & & & & & & & & & & & & 4750 \\
\hline & & & & & & & & & & & & 434.0 \\
\hline & & & & & & & & & & & & 270.0 \\
\hline & & & & & & & & & & & & 306.0 \\
\hline & & & & & & & & & & & & 3970 \\
\hline & & & & & & & & & & & & 2810 \\
\hline & & & & & & & & & & & & 3070 \\
\hline & & & & & & & & & & & & 3750 \\
\hline & & & & & & & & & & & & 3150 \\
\hline & & & & & & & & & & & & 4090 \\
\hline & & & & & & & & & & & & 4290 \\
\hline & & & & & & & & & & & & 3150 \\
\hline & & & & & & & & & & & & 4340 \\
\hline & & & & & & & & & & & & 348.0 \\
\hline & & & & & & & & & & & & 4500 \\
\hline & & & & & & & & & & & & 4570 \\
\hline
\end{tabular}




\begin{tabular}{|c|c|c|c|c|c|c|c|c|c|c|c|}
\hline Author & Area & ar $\mathrm{nr}$ & Depth (m) & Sample & Nem & Cop & Turb & Pol & Oli & Ostr & Hydr \\
\hline $\begin{array}{l}\text { Soltwedel, } \\
\text { unpubl } \\
\text { Gooday, }\end{array}$ & Biotrans & $\begin{array}{l}12 \\
12 \\
12 \\
12\end{array}$ & 4560 & $\begin{array}{r}113 \\
114 \\
115 \\
179(2)\end{array}$ & $\begin{array}{l}124.8 \\
229.0 \\
120.4 \\
760.1\end{array}$ & $\begin{array}{l}200 \\
400 \\
150 \\
530\end{array}$ & $\begin{array}{ll}0 & 0 \\
0 & 0 \\
0 & 0 \\
0 & 0\end{array}$ & $\begin{array}{ll}0 & 0 \\
5 & 8 \\
2 & 9 \\
0 & 0\end{array}$ & $\begin{array}{l}0.0 \\
0.0 \\
0.0 \\
0.0\end{array}$ & $\begin{array}{ll}0 & 0 \\
2 & 0 \\
0 & 0 \\
0 & 0\end{array}$ & $\begin{array}{ll}0 & 0 \\
0 & 0 \\
0.0 & 0 \\
0.0\end{array}$ \\
\hline $\begin{array}{l}\text { unpubl } \\
\text { Rutgers } \\
\text { and Lavaleye, } \\
1986\end{array}$ & DORA & $\begin{array}{l}11 \\
11 \\
11 \\
11 \\
11 \\
11 \\
11 \\
11 \\
11 \\
11 \\
11 \\
11 \\
11 \\
11 \\
11\end{array}$ & $\begin{array}{l}4787 \\
4325 \\
4333 \\
4310 \\
3958 \\
4723 \\
4540 \\
4800 \\
4200 \\
4300 \\
4570 \\
4725 \\
4725 \\
4700 \\
4000\end{array}$ & $\begin{array}{r}21 \\
5 \\
23 \\
22 \\
24 \\
25 \\
26 \\
1 \\
2 \\
4 \\
6 \\
8 \\
11 \\
13 \\
15\end{array}$ & $\begin{array}{l}315.0 \\
386.0 \\
5340 \\
4030 \\
5600 \\
6220 \\
7200 \\
3220 \\
1010 \\
2460 \\
300.0 \\
373.0 \\
401.0 \\
595.0 \\
985.0\end{array}$ & $\begin{array}{r}10.5 \\
16.7 \\
14.7 \\
3.9 \\
19.3 \\
16.1 \\
12.0 \\
5.7 \\
9.7 \\
117 \\
154 \\
130 \\
126 \\
321 \\
487\end{array}$ & 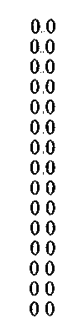 & 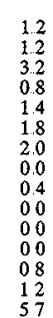 & $\begin{array}{ll}0 & 0 \\
0 & 0 \\
0 & 0 \\
0 & 0 \\
0 & 0 \\
0.0 \\
0.0 \\
0.0 \\
0.0 \\
0.0 \\
0.0 \\
0.0 \\
0.0 \\
0.0 \\
0 & 0 \\
0.0 \\
0 & 0\end{array}$ & $\begin{array}{l}0.6 \\
2.0 \\
2.0 \\
1.2 \\
0.8 \\
06 \\
06 \\
04 \\
08 \\
08 \\
04 \\
0.4 \\
0.8 \\
0.4 \\
2.4\end{array}$ & $\begin{array}{ll}0 & 0 \\
0 & 0 \\
0 & 0 \\
0 & 0 \\
0 & 0 \\
0.0 \\
0.0 \\
0.0 \\
0.0 \\
0.0 \\
0.0 \\
0.0 \\
0.0 \\
0.0 \\
0.0\end{array}$ \\
\hline $\begin{array}{l}\text { Thiel, } \\
1972\end{array}$ & Iberic sea & $\begin{array}{l}13 \\
13 \\
13 \\
13 \\
13 \\
13 \\
13 \\
13 \\
13 \\
13 \\
13\end{array}$ & $\begin{array}{l}5325 \\
5325 \\
5335 \\
5340 \\
5340 \\
5305 \\
5305 \\
5320 \\
5320 \\
5272 \\
5272\end{array}$ & $\begin{array}{l}12-89-1 \\
12-89-2 \\
18-91-1 \\
21-92-1 \\
21-92-2 \\
29-93-1 \\
29-93-2 \\
31-94-1 \\
31-94-2 \\
35-95-1 \\
35-95-2\end{array}$ & $\begin{array}{r}156.0 \\
246.0 \\
192.0 \\
172.0 \\
80.0 \\
242.0 \\
200.0 \\
256.0 \\
1760 \\
3020 \\
2570\end{array}$ & $\begin{array}{r}30 \\
60 \\
56 \\
36 \\
20 \\
16 \\
44 \\
56 \\
24 \\
10.4 \\
48\end{array}$ & $\begin{array}{l}0.0 \\
0.0 \\
0.0 \\
0.0 \\
0.0 \\
0.0 \\
0.0 \\
0.0 \\
0.0 \\
0.0 \\
0.0\end{array}$ & $\begin{array}{l}04 \\
0.4 \\
04 \\
0.0 \\
0.0 \\
0.4 \\
0.4 \\
0.0 \\
0.8 \\
12 \\
12\end{array}$ & $\begin{array}{ll}0 & 0 \\
0 & 0 \\
0 & 0 \\
0.0 \\
0.0 \\
0.0 \\
0.0 \\
0.0 \\
0.0 \\
0.0 \\
0.0 \\
0.0 \\
0 & 0\end{array}$ & $\begin{array}{ll}0.0 \\
1.2 \\
12 \\
08 \\
16 \\
00 \\
04 \\
20 \\
12 \\
22 \\
22\end{array}$ & $\begin{array}{ll}0 & 0 \\
0 & 0 \\
0 & 0 \\
0.0 & 0 \\
0.0 & 0 \\
0.0 \\
0.0 \\
0.0 \\
0.0 \\
0.0 \\
0.0\end{array}$ \\
\hline , & $\begin{array}{l}\text { Mauretania } \\
\text { Mauretania } \\
\text { Gr. Met seam. } \\
\text { Morocco } \\
\text { Gibraltar } \\
\text { Portugal } \\
\text { Mauretania } \\
\text { Morocco } \\
\text { Gibraltar } \\
\text { Portugal } \\
\text { Gr. Met. seam. } \\
\text { Morocco } \\
\text { Portugal } \\
\text { Mauretania } \\
\text { Morocco } \\
\text { Portugal } \\
\text { Mauretania } \\
\text { Portugal } \\
\text { Morocco } \\
\text { Portugal }\end{array}$ & $\begin{array}{l}26 \\
26 \\
24 \\
20 \\
17 \\
14 \\
26 \\
20 \\
17 \\
14 \\
25 \\
21 \\
15 \\
27 \\
21 \\
15 \\
27 \\
16 \\
22 \\
16\end{array}$ & $\begin{array}{l}750-1250 \\
\\
1250-1750 \\
1750-2250 \\
\\
\\
2750-3250 \\
3750-4250 \\
4250-4750 \\
4750-5250\end{array}$ & & & & & & & & \\
\hline
\end{tabular}

which were living when collected, Gooday (1986a, b, 1988) and Gooday and Lambshead (1989) mounted stained specimens in glycerol and examined them under a compound microscope to ensure that the stained material was foraminiferal protoplasm. Only specimens with a convincing protoplasmic mass were regarded as living.

A controversial issue in benthic research is the standardization of size groups. During the Sixth Deep-Sea Biology Symposium in Copenhagen (1991), a workshop was organized by Hjalmar Thiel on the "Standardization of methods for benthos studies and biochemical measurements in sediments" (Thiel, 1993). For meiobenthos, this workshop recommended a lower limit of $31 \mu \mathrm{m}$ and an upper limit of $1 \mathrm{~mm}$ for all benthic work in the deep sea. In fact, these mesh-size based categories have little ecological and even less taxonomic justification in the deep sea because a 


\begin{tabular}{|c|c|c|c|c|c|c|c|c|c|c|c|c|c|c|}
\hline Gas & Iar & $\mathrm{Kin}$ & Amp & Hal & Lor & Iso & Biv & $\operatorname{Ian}$ & Others & Fora & Meio & Metaz & $\underset{(\%)}{\mathrm{Nem}}$ & $\begin{array}{l}\text { Cop } \\
(\%)\end{array}$ \\
\hline $\begin{array}{ll}0 & 0 \\
0 & 0 \\
0 & 0 \\
0 & 0\end{array}$ & $\begin{array}{l}0.0 \\
0.0 \\
0.0 \\
0.0\end{array}$ & $\begin{array}{ll}0 & 0 \\
1 & 0 \\
0 & 0 \\
0 & 0\end{array}$ & $\begin{array}{l}0.0 \\
0.0 \\
0.0 \\
0.0\end{array}$ & $\begin{array}{ll}0.0 \\
0 & 0 \\
0.0 \\
0 & 0\end{array}$ & $\begin{array}{l}0.0 \\
0.0 \\
0.0 \\
0.0\end{array}$ & $\begin{array}{l}0.0 \\
0.0 \\
0.0 \\
0.0\end{array}$ & $\begin{array}{l}0.0 \\
0.0 \\
0.0 \\
0.0\end{array}$ & $\begin{array}{ll}0 & 0 \\
0 & 0 \\
0 & 0 \\
0 & 0\end{array}$ & $\begin{array}{l}2.6 \\
2.0 \\
0.0 \\
0.0\end{array}$ & $\begin{array}{l}196.0 \\
319.0 \\
4643 \\
8642\end{array}$ & $\begin{array}{r}343.4 \\
598.8 \\
602.6 \\
1677.3\end{array}$ & $\begin{array}{l}147.4 \\
279.8 \\
138.3 \\
813.1\end{array}$ & $\begin{array}{l}84.7 \\
81.8 \\
87.1 \\
93.5\end{array}$ & $\begin{array}{r}136 \\
143 \\
108 \\
6.5\end{array}$ \\
\hline $\begin{array}{lll}0 & 0 \\
0 & 0 \\
0 & 0 \\
0 & 0 \\
0.0 & 0 \\
0.0 & 0 \\
0.0 & 0 \\
0.0 & 0 \\
0.0 & 0 \\
0 & 0 \\
0 & 0 \\
0 & 0 \\
0.0 & 0 \\
0.0 & 0 \\
0.0 & 0 \\
0 & 0 \\
0 & 0 \\
0 & 0 \\
0.0 & 0 \\
0.0 & 0 \\
0.0 & 0 \\
0.0 & 0 \\
0 & 0 \\
0 & 0 \\
0 & 0 \\
0 & 0\end{array}$ & 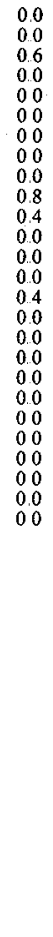 & $\begin{array}{lll}0.2 & 2 \\
0 & 0 \\
1 & 0 \\
0 & 0 \\
0 & 2 \\
0 & 2 \\
0 & 0 \\
0 & 3 \\
0.0 \\
0 & 0 \\
0 & 0 \\
0.0 & 0 \\
0 & 8 \\
0 & 0 \\
0 & 0 \\
1 & 2 \\
0 & 0 \\
0.0 & 0 \\
0.0 & 0 \\
0 & 0 \\
0 & 0 \\
0 & 0 \\
0 & 0 \\
0 & 0 \\
0 & 0 \\
0 & 0 \\
0 & 0\end{array}$ & $\begin{array}{ll}0 & 0 \\
0 & 0 \\
0 & 0 \\
0 & 0 \\
0 & 0 \\
0 & 0 \\
0 & 0 \\
0 & 0 \\
0 & 0 \\
0.0 & 0 \\
0 & 0 \\
0 & 0 \\
0 & 0 \\
0 & 0 \\
0 & 0 \\
0 & 0 \\
0 & 0 \\
0 & 0 \\
0 & 0 \\
0 & 0 \\
0 & 0 \\
0 & 0 \\
0 & 0 \\
0 & 0 \\
0 & 0 \\
0 & 0 \\
0 & 0\end{array}$ & $\begin{array}{lll}0 & 0 \\
0 & 0 \\
0 & 0 \\
0 & 0 & 0 \\
0 & 0 & 0 \\
0 & 0 & 0 \\
0 & 0 & 0 \\
0 & 0 \\
0 & 0 \\
0 & 0 \\
0 & 0 \\
0 & 0 \\
0 & 0 \\
0 & 0 \\
0 & 0 \\
0 & 0 \\
0 & 0 \\
0 & 0 \\
0 & 0 \\
0 & 0 \\
0 & 0 \\
0 & 4 \\
0 & 4 \\
0 & 0 \\
0 & 0 \\
0 & 0\end{array}$ & 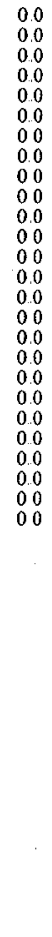 & $\begin{array}{l}0.0 \\
00 \\
00 \\
0.0 \\
0.0 \\
0.0 \\
0.0 \\
0.0 \\
0.0 \\
0.0 \\
00 \\
00 \\
00 \\
00 \\
00 \\
00 \\
00 \\
00 \\
00 \\
00 \\
0.4 \\
0.0 \\
0.0 \\
0.0 \\
000 \\
0.0\end{array}$ & $\begin{array}{l}0.0 \\
00 \\
0.0 \\
0.2 \\
0.2 \\
0.2 \\
0.0 \\
0.0 \\
00 \\
0.4 \\
00 \\
00 \\
00 \\
00 \\
0.8 \\
0.8 \\
0.0 \\
0.0 \\
0.0 \\
0.0 \\
0.0 \\
0.0 \\
0.0 \\
0.0 \\
00 \\
0.0\end{array}$ & 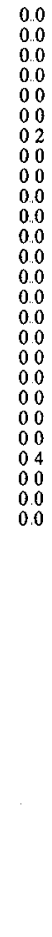 & $\begin{array}{r}48 \\
187 \\
4.6 \\
2.2 \\
5.4 \\
8.8 \\
8.4 \\
2.4 \\
2.9 \\
1.2 \\
11.0 \\
81 \\
24 \\
167 \\
61 \\
00 \\
0.0 \\
0.0 \\
0.0 \\
0.0 \\
0.0 \\
0.0 \\
0.0 \\
0.0 \\
00 \\
00\end{array}$ & $\begin{array}{r}12.6 \\
37.8 \\
22.8 \\
4.6 \\
68 \\
46 \\
11.2 \\
228 \\
6.1 \\
1.2 \\
138 \\
191 \\
7.3 \\
7.3 \\
34.1\end{array}$ & $\begin{array}{r}374.2 \\
462.1 \\
6673 \\
4536 \\
6303 \\
7053 \\
8314 \\
352.9 \\
130.6 \\
262.5 \\
341.4 \\
415.7 \\
429.1 \\
669.5 \\
11209\end{array}$ & $\begin{array}{r}361.6 \\
424.3 \\
644.5 \\
449.0 \\
623.5 \\
700.7 \\
8202 \\
3301 \\
124.5 \\
261.3 \\
327.6 \\
396.6 \\
421.8 \\
662.2 \\
1086.8 \\
162.0 \\
2570 \\
200.0 \\
1760 \\
84.0 \\
245.0 \\
210.0 \\
264.0 \\
180.0 \\
317.0 \\
366.0 \\
156.0 \\
417.0 \\
246.0 \\
629.0 \\
370.0 \\
1387.0 \\
1082.0 \\
331.0 \\
298.0 \\
1250.0 \\
48.0 \\
306.0 \\
521.0 \\
315.0 \\
140.0 \\
474.0 \\
1099.0 \\
1920 \\
1300 \\
123.0\end{array}$ & $\begin{array}{l}87.1 \\
91.0 \\
82.9 \\
89.8 \\
89.8 \\
88.8 \\
878 \\
975 \\
811 \\
941 \\
916 \\
940 \\
951 \\
899 \\
906 \\
96.3 \\
95.7 \\
96.0 \\
97.7 \\
95.2 \\
988 \\
952 \\
970 \\
978 \\
953 \\
702\end{array}$ & $\begin{array}{l}2.9 \\
3.9 \\
2.3 \\
0.9 \\
3.1 \\
2.3 \\
15 \\
17 \\
7.8 \\
45 \\
47 \\
33 \\
3.0 \\
4.8 \\
4.5 \\
19 \\
2.3 \\
2.8 \\
2.0 \\
2.4 \\
0.7 \\
2.1 \\
2.1 \\
1.3 \\
3.3 \\
1.3\end{array}$ \\
\hline
\end{tabular}

trend towards miniaturization has occurred among the benthos above the size of nanobenthos (Thiel, 1975). This trend has not affected the larger macrofauna and megafauna in which, for some taxa, a reverse trend towards gigantism has occurred.

Therefore, as suggested by Hessler and Jumars (1974), the use of the term "meiobenthic taxa" is more appropriate in the context of deep-sea habitats. These taxa consist of metazoan animals traditionally regarded as "meiobenthos", and larger protozoans, almost exclusively foraminifera. Nearly all meiobenthic phyla have been found in deep-sea sediments. The numerical dominance of a few taxa, notably foraminifera, nematodes and copepods, however, is more pronounced in comparison with shallower areas. 


\section{ENVIRONMENTAL VARIABLES}

\subsection{Sediment Type}

Bottom sediments in the northeast Atlantic originate from terrestrial or volcanic sources, from turbidity currents and related catastrophic phenomena, from bottom currents and from pelagic sedimentation. In general, coarse sediments (sands and gravels) of terrestrial or biogenic origin are restricted to the continental shelf and upper slope and become progressively finer (silty muds and muds) with increasing bathymetric depth and distance from land (Emery and Uchupi, 1984; Auffret, 1985; Lampitt et al., 1986). However, in some areas, for example off the western approaches to the English Channel (Mart et al., 1979; Auffret, 1985; Weston, 1985), the continental slope is dissected by active submarine canyons which channel coarse sediments onto the continental slope and rise. Coal, clinker (derived from steamships) and ice-rafted debris are also widespread in the northeast Atlantic (Kidd and Huggett, 1981) and provide a substratum for sessile organisms.

Over much of the northeast Atlantic the superficial sediments consist of pelagic calcareous oozes with a calcium carbonate content exceeding 30 or $50 \%$ and a mean particle size of $<0.01 \mathrm{~mm}$ (Apostolescu et al., 1978; Emery and Uchupi, 1984; Auffret, 1985; Lampitt et al., 1986; Udintsev et al., 1989-1990). Clay particles $(<0.01 \mathrm{~mm})$ generally make up $50 \%$ or more of the sediment (Udintsev et al., 1989-1990). The carbonate compensation depth (CCD) in the northeast Atlantic exceeds $5000 \mathrm{~m}$ (Berger, 1975; Biscaye et al., 1976) and hence areas of very fine grained red clay (from which the carbonate has been removed by dissolution) are restricted to the deepest basins, located west and northwest of the Cape Verde Islands.

Many continental slopes in the northeast Atlantic are characterized by widespread slope failure leading to turbidity currents, debris flows and sediment slides which have deposited sediments across huge areas of the adjacent rise and abyssal plain (Emery and Uchupi, 1984; Stein, 1991). Sediment slides and debris flows have been most fully described off the northwest African coast where some cover a great area (Embley, 1976; Jacobi, 1976; Kidd et al., 1986; Masson et al., 1994). Turbidity currents originating from slope failure may travel considerable distances across the ocean floor, depositing progressively finer sediments as they do so. Distal turbidites are typically fine grained and carbonate rich and have a higher total organic carbon content (1-3\%) than sediments of pelagic origin (Wilson and Wallace, 1990; Stein, 1991). Such deposits are known to blanket the Madeira Abyssal Plain where the Quaternary succession consists of thick turbidite units separated by thin pelagic layers (Weaver 
and Kuijpers, 1983; Weaver et al., 1986). They clearly influence the abyssal biota since areas of the Madeira Abyssal Plain underlain by turbiditic and pelagic sediments have quite different assemblages of animal traces (Huggett, 1986).

Turbidity currents must have devastated benthic life over large tracts of ocean floor and controlled the nature of recolonizing communities. However, such events have been rare along the northwest African margin with only one major turbidite being deposited, on average, every 30000 years during the last 730000 years (Masson et al., 1994). Hence, all but the most recent turbidites are blanketed by pelagic sediments. Bottom current deposits (contourites) are well developed on the abyssal aprons, for example around the Rockall Plateau (Hill, 1987).

Detailed information on sediment grain size composition of the areas (Figure 1) reviewed in this chapter are only available for area 6 (Vanreusel et al., 1992), areas 7-10 (Dinet and Vivier, 1977) and area 13 (Thiel, 1972a). Some areas less than $1000 \mathrm{~m}$ deep have coarser sediments, while most of the other areas are characterized by fine silty clays.

\subsection{Oxygen}

Unlike those in shallow water, deep-sea sediments are usually well oxygenated. Oxygen profiles for abyssal plain sediments in the northeast Atlantic are given by Sorensen and Wilson (1984), Wilson et al. (1985, 1986), Wallace et al. (1988), Rutgers van der Loeff and Lavaleye (1986) and Rutgers van der Loeff (1991) (area 11; Figure 2). Oxygen invariably penetrates to a depth of at least several decimetres and usually much deeper. At Discovery Station 10554 on the Madeira Abyssal Plain (area 23), oxygen levels were reduced to zero at a depth of less than $30 \mathrm{~cm}$ (Wilson et al., 1985, 1986). This was attributed by Wilson et al. (1985) to the oxidation of organic matter in a turbidite layer. A relatively shallow depth $(25-30 \mathrm{~cm})$ of oxygen penetration was also observed by Rutgers van der Loeff (1991) (area 11) in a core from the Porcupine Abyssal Plain. However, even at such localities, meiobenthos living in the upper $5 \mathrm{~cm}$ of sediment in the northeast Atlantic should not normally experience a lack or shortage of oxygen.

\subsection{Food Supply}

Food availability often exerts a decisive influence on faunal densities. Except around hydrothermal vents, the food that sustains benthic communities originates mainly from surface water primary production 


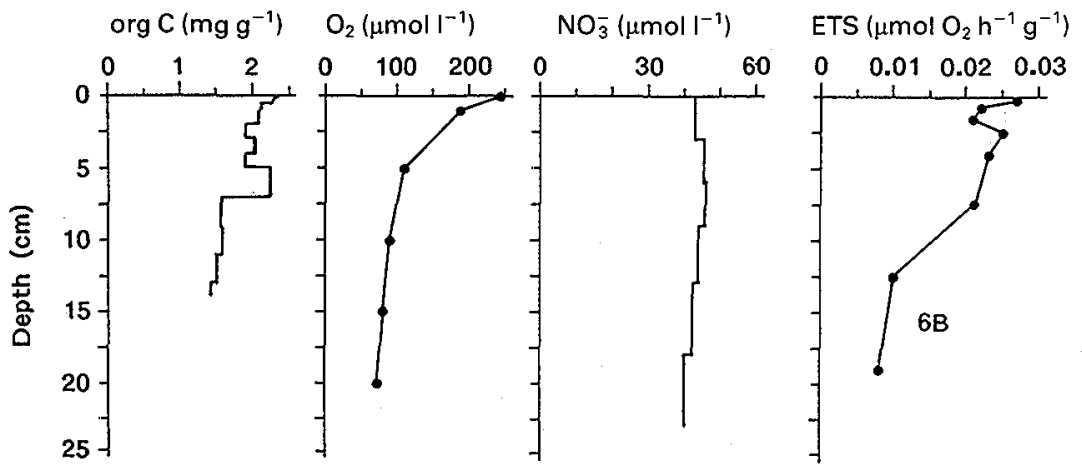

Figure 2 Vertical profiles in the sediment of organic carbon, $\mathrm{O}_{2}, \mathrm{NO}_{3}^{-}$and ETS activity at the DORA site (area 11; sample 6B) (after Rutgers van der Loeff and Lavaleye, 1986).

with some input from terrestrial sources. The most recent map of surface production in the Atlantic Ocean (the "Dahlem Map"; Berger, 1989: Figure 3) shows decreasing values from the northern margin of our region to about $35^{\circ} \mathrm{N}$. Further south surface productivity increases in association with the coastal upwelling off northwest Africa. Export production (net particulate flux of carbon across the thermocline) shows a similar pattern (Berger et al., 1988).

Only scattered data are available regarding the distribution of organic matter in northeast Atlantic sediments. Emery and Uchupi (1984) present a generalized map, based on literature sources, showing the organic carbon content of dried sediment for the whole of the Atlantic. In the northeastern part, values tend to decrease with increasing bathymetric depth. Seaward of the continental margin the organic carbon content generally lies between 0.25 and $0.50 \%$ with a southwest to northeast trending zone of higher values $(0.5-1.0 \%)$ between about $25-35^{\circ} \mathrm{N}$ and $20-40^{\circ} \mathrm{W}$. According to Sibuet (1984), the organic carbon content of sediments from deep basins in the Atlantic Ocean varies from 0.17 to $0.85 \%$. Auffret (1985) gives values ranging from 0.2 to $0.7 \%$ at depths between 2000 and $4800 \mathrm{~m}$ in the Bay of Biscay. CHN analyses of Porcupine Seabight sediments after acid digestion yield organic carbon values of $0.5 \%$ dry weight with no distinct trend with depth (Rice et al., 1991). Higher values $(0.5-4.0 \%)$ have been recorded in late Pliocene and Pleistocene sediments from ODP (Ocean Drilling Project) site 658, situated under the upwelling area off Cap Blanc (Stein, 1991). As noted above, higher values are also associated with turbiditic sediments.

A more meaningful indication of food availability is provided by 


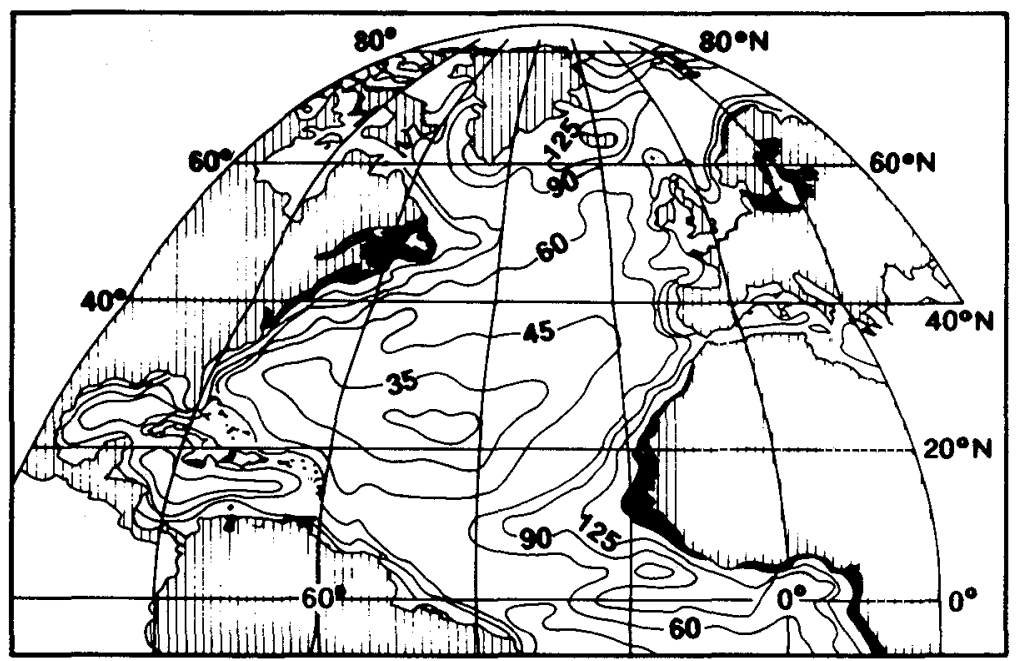

Figure 3 Surface primary production $\left(\mathrm{g} \mathrm{C} \mathrm{m}^{-2}\right.$ year $\left.{ }^{-1}\right)$ map of the North Atlantic (after Berget, 1989). Black areas near the coast indicate values $>150 \mathrm{~g} \mathrm{C} \mathrm{m}^{-2}$ year $^{-1}$.

chloroplastic pigment equivalents (CPE) which reflect the amount of organic matter originating from primary production. Detailed information of CPE values from particular areas off northwest Africa and Europe are given by Thiel (1978, 1983), Pfannkuche et al. (1983) (area 18), Pfannkuche (1985) (areas 1-4). Off northwest Africa, particularly high CPE values in the sediments are associated with intense upwelling; although the patterns are complicated by local currents which influence the deposition of organic matter (Thiel, 1978, 1982; Pfannkuche et al., 1983).

Most chloroplastic pigments probably originate from phytodetritus which represents an important mechanism for rapidly delivering organic matter originating from surface production to the ocean floor (Gooday and Turley, 1990). Large amounts of this material have been observed on the ocean floor in the Porcupine Seabight (areas 1-3), on the Porcupine Abyssal Plain (area 4) (Billett et al., 1983; Lampitt, 1985; Rice et al., 1986, 1991), the BIOTRANS area (area 12) (Thiel et al., 1989-1990), the Rockall Trough and the Bay of Biscay (Gooday and Turley, 1990). In these northern areas, phytodetritus deposition seems to be associated with deep (>500 m) winter mixing (Robinson et al., 1979), in addition to relatively high surface productivity. However, recent evidence indicates that phytodetritus is also deposited further south in areas where the mixed layer is $<150 \mathrm{~m}$ in depth. Christiansen and Thiel (1992) observed 
abundant flocculent material in depressions and around mounds on the Madeira Abyssal Plain ( $\left.34^{\circ} \mathrm{N}\right)$ and small amounts were present in multiple corer samples taken at the IOSDL southern site $\left(31^{\circ} \mathrm{N}\right)$. Phytodetritus has also been photographed on the seafloor even further south, at $19^{\circ} \mathrm{S}$ (McCave, 1991). Pfannkuche (1993b) provided data on seasonal variation in CPE.

\subsection{Deep Bottom Water Masses}

In the North Atlantic, and other oceanic regions, some modern foraminiferal species assemblages show good local correlations with the water masses which bathe the ocean floor (Streeter, 1973; Schnitker, 1980; Weston and Murray, 1984). A similar correlation has not been established for meiobenthic taxa other than foraminifera, but this may reflect a general lack of species level distributional data for the metazoan meiobenthos. The only other examples of a correlation between water mass and animal distributions in the deep sea are provided by Patterson $e t$ al. (1982) for five North Atlantic species of the ophiuroid genus Ophiocten and by Tyler and Zibrowius (1992) for suspension feeding echinoderms southwest of Iceland. In the latter case the associations clearly are linked to the current activity rather than to water masses as such.

In the eastern North Atlantic, the deep waters consist mainly of North Atlantic Deep Water (NADW), a composite water mass with an upper, low salinity $(<34.94 \%$ ) layer, a middle layer of Norwegian Overflow Water (salinity 34.96-35.03\%o), and a lower layer which consists of Norwegian Overflow Water diluted by mixing with Denmark Strait Overflow Water (Worthington, 1976; Weston and Murray, 1984; Gage and Tyler, 1991). The upper NADW layer, which unlike the lower layer originates from the Labrador Sea, is often considered as a separate entity, the North East Atlantic Deep Water (NEADW). At depths less than about $2000 \mathrm{~m}$, the dominant water mass in the northeast Atlantic is Mediterranean Water which flows through the Straits of Gibraltar, around the European continental margin, through the Rockall Trough and into the Norwegian Sea, becoming progressively diluted as it proceeds northwards. Mediterranean Water is characterized by its high density and salinity and by its variable physical properties (Weston, 1985).

Below about $4500 \mathrm{~m}$, the deep basins off the African coast are occupied by a distinct water mass which originates from the Antarctic. This Antarctic Bottom Water (AABW) is restricted to areas south of about $36^{\circ} \mathrm{N}$, where its passage is blocked by ridges associated with the Azores 
Fracture Zone. AABW is characterized by low temperatures and salinities and by relatively high dissolved oxygen and nutrient concentrations.

\subsection{Near-bottom Currents}

In the northwest Atlantic, unusually high current speeds $\left(20-25 \mathrm{~cm} \mathrm{~s}^{-1}\right)$ occur during periodic "benthic storms" which originate when eddy kinetic energy derived from near-surface eddies impinges on the ocean floor (Richardson et al., 1981; Hollister and McCave, 1984; Gross et al., 1988). These events erode and redistribute bottom sediments and strongly influence the character of meiobenthic communities (e.g. Thistle et al., 1985). Recently there has been some evidence for benthic storms in the northeast Atlantic; currents capable of eroding and depositing sediments are associated with the sediment drifts which are extensively developed to the west of the Rockall Trough and elsewhere (Emery and Uchupi, 1984). At BIOTRANS (area 12), the deep mean flow is $3-5 \mathrm{~cm} \mathrm{~s}^{-1}$ but benthic storms occur with durations between 3 and 27 days with maximum velocities of $27 \mathrm{~cm} \mathrm{~s}^{-1}$ (Klein and Mittelstaedt, 1992). Maximum current velocities here may approach $40 \mathrm{~cm} \mathrm{~s}^{-1}$ (Dickson and Kidd, 1987) and must have an impact on the benthic fauna similar to that described by Thistle et al. (1985). Away from such areas, the near-bottom currents are fairly gentle and probably have little impact on the meiobenthos beyond the transportation of nutrients and larvae. A residual boundary current flows northward along the continental margin of northwestern Europe and has superimposed on it diurnal or semidiurnal tidal currents (Dickson et al., 1986). Rice et al. (1991) summarize information on currents flowing near the floor of the Porcupine Seabight. At a depth of $4025 \mathrm{~m}$, near the mouth of the Seabight, current speeds varied semidiurnally and reached a maximum on the western side of the Porcupine Bank (Norris and McDonald, 1986). Measurements made during the BIOGAS programme indicate current speeds of generally less than $10 \mathrm{~cm} \mathrm{~s}^{-1}$ at abyssal depths (Vangriesheim, 1985). Current speeds in more central oceanic regions are presumably lower than along the continental margins.

\section{HORIZONTAL SPATIAL PATTERNS}

When comparing quantitative meiobenthos data at an ocean-wide scale, one must take account of the variability in population density on different 
scales: from small-scale (within one corer) and medium-scale (between corers from nearby locations) to large-scale (ocean-wide scale; e.g. Thiel, 1983). In this section both bathymetric and latitudinal trends in meiobenthic density, and composition at different taxonomic levels, will be discussed. The lack of standardization in sampling (Bett et al., 1994) and in processing techniques (e.g. different mesh sizes) complicates the comparison of data from different meiobenthic investigations. Data evaluation is therefore a challenge and observations of differences in faunal densities and changes in faunal composition have to be made with some caution.

\subsection{Bathymetric Trends}

\subsubsection{Faunal Densities}

There is a general tendency (see reviews Thiel, 1983 and Tietjen, 1992) for metazoan meiobenthic densities to decrease with increasing bathymetric depth within limited geographical areas (i.e. under constant climatological and ecophysiological life conditions). This tendency does not hold for the total northeast Atlantic ocean, as illustrated in Figure 4, in which the mean densities per area are plotted as a function of mean water depth. In general the lowest densities are recorded at abyssal depths where mean densities for each area are never higher than 600 individuals (ind) $/ 10 \mathrm{~cm}^{2}$, and the highest densities are found in the shallowest areas $\left(<1000 \mathrm{~m}\right.$ : mean per area up to 2000 ind $\left./ 10 \mathrm{~cm}^{2}\right)$, but occasionally densities of less than $500 \mathrm{ind} / 10 \mathrm{~cm}^{2}$ are recorded on the upper slope and in the shelf break area.

Densities do not always decrease in relation to depth within smaller geographical regions (Figure 5) which may show different and sometimes conflicting patterns of density gradients: for example off Mauretania, off Morocco, off Gibraltar, in the Bay of Biscay, and on the Iberian, Madeiran and Porcupine abyssal plains.

In the southern part of the northeast Atlantic, off the coast of Mauretania, densities were relatively high at the deepest sites (areas 27, 28 and 29: means $500-1000$ ind $/ 10 \mathrm{~cm}^{2}$ ), higher than on the upper slope and in the shelf break area (area 26: 500 ind $/ 10 \mathrm{~cm}^{2}$ ) (Thiel, 1975; Dinet, unpublished). The lack of any depth-associated gradient in this area, and the relatively high densities on the lower part of the slope, are due to increased primary production resulting from intense upwelling activity in the water column, and providing high food input to these deeper areas. Low densities on the upper slope can be explained by hydrodynamic processes, which cause erosion and prevent organic matter from reaching 


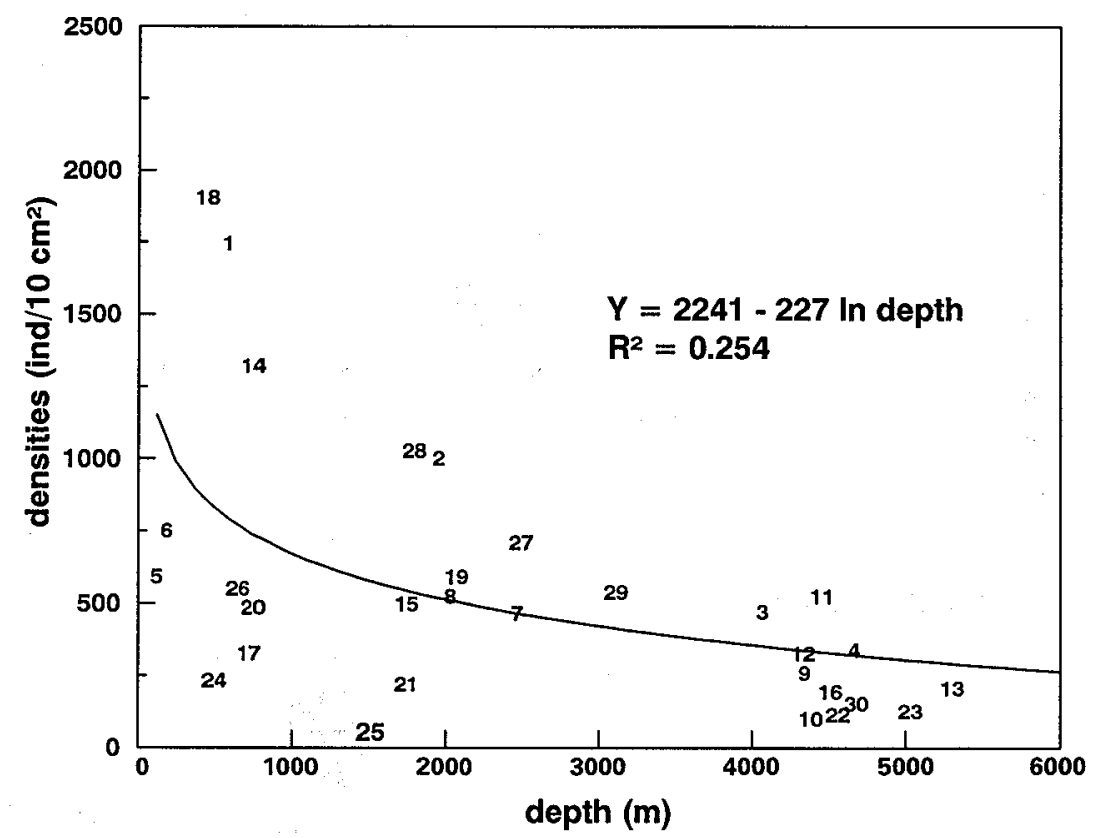

Figure 4 The relationship between mean metazoan density and mean water depth of each area (30 areas as defined in Table 1) in the northeast Atlantic.

the seafloor (Thiel, 1983). At the oligotrophic abyssal site (area 30) situated on the same latitude, and intensively studied by the EUMELI project (Dinet, unpublished), much lower densities are found in comparison to the slope $\left(200 \mathrm{ind} / 10 \mathrm{~cm}^{2}\right)$.

Along the NW African coast, off Morocco, densities are in general low. Some higher values were recorded for the upper slope (area 20:500 ind $/ 10 \mathrm{~cm}^{2}$ ), but deeper down the meiobenthos is very poorly represented (areas 21 and 22: $<250 \mathrm{ind} / 10 \mathrm{~cm}^{2}$ ). From $1000 \mathrm{~m}$ depth, the densities are similar to those of area 23 on the Madeira Abyssal Plain, which has been intensively investigated by IOSDL (Gooday, unpublished).

Two relatively shallow $(<1750 \mathrm{~m})$ sites located on the Great Meteor seamount, near the western border of the Madeira Abyssal Plain, also have low meiobenthic densities (areas 24 and 25: $<250 \mathrm{ind} / 10 \mathrm{~cm}^{2}$ ). Beside their central oceanic location, a higher predation pressure and current activity are possible causes of the low abundances (Thiel, 1983).

Off Gibraltar, Thiel (1975) found much lower densities on the upper slope (area 17:300 ind $/ 10 \mathrm{~cm}^{2}$ ) than Pfannkuche et al. (1983) on a nearby transect off the African coast (areas 18 and 19: 600-2000 ind $10 \mathrm{~cm}^{2}$ ). In the latter study, meiobenthic abundances showed a significant correlation with CPE concentrations, which decreased with water depth. Thiel (1983) 


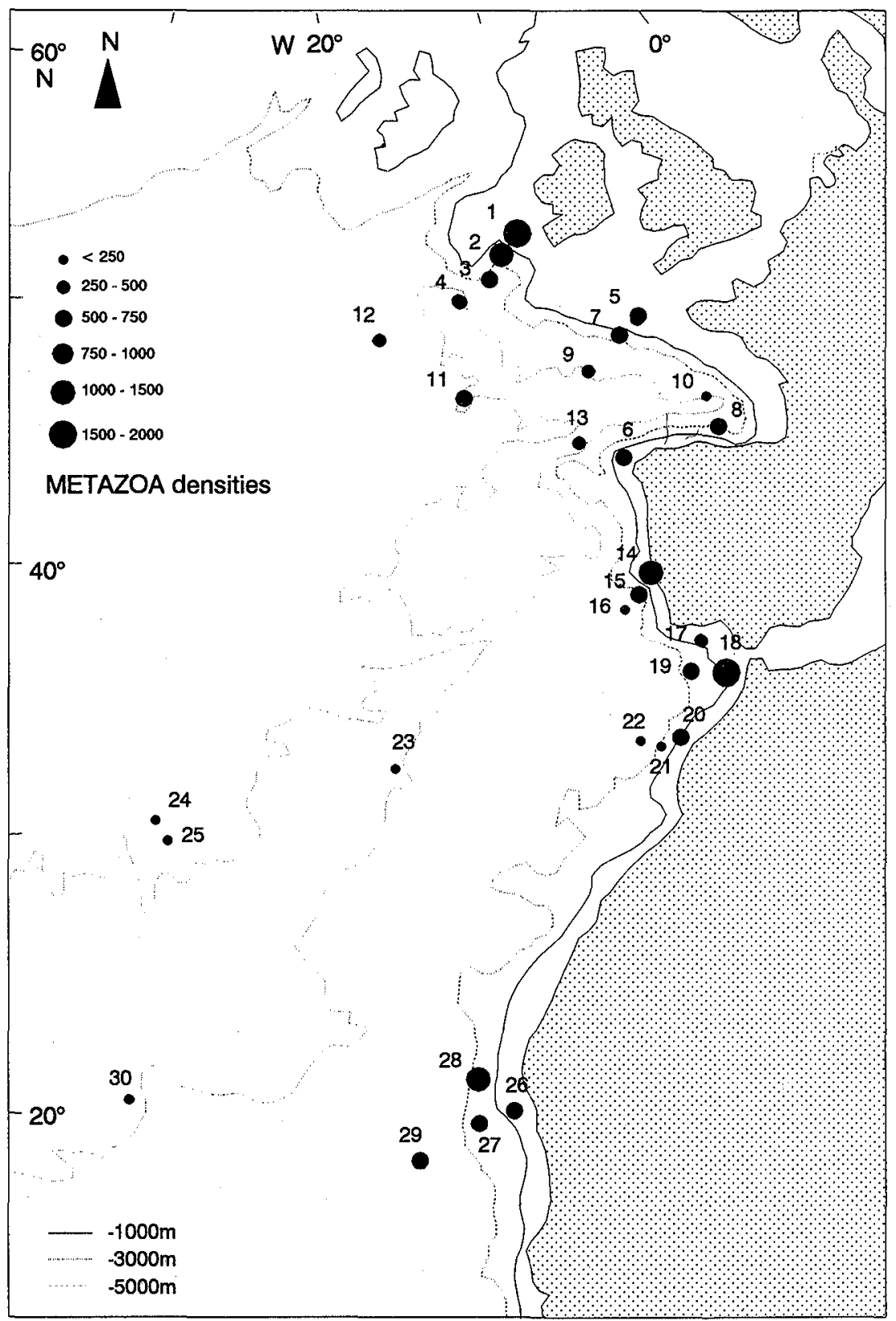

Figure 5 Map of the northeast Atlantic showing the mean metazoan density for each area (as defined in Table 1) (ind $10 \mathrm{~cm}^{2}$ ). 
explained the lower densities found during the Meteor 21 cruise by the outflow of warm Mediterranean water, which accelerates along the Atlantic slope due to its higher density, preventing the sedimentation of detritus.

On a transect near the Portuguese coast (Thiel, 1975), meiobenthic densities decrease from 1400 to $100 \mathrm{ind} / 10 \mathrm{~cm}^{2}$ in relation to bathymetric depth (areas 14, 15 and 16).

In the Bay of Biscay, densities decrease more-or-less with depth, although the upper slope and the shelf break sites are characterized by relatively low numbers (areas 5, 6, 7 and 8: $450-750$ ind $/ 10 \mathrm{~cm}^{2}$ ) (Vanreusel et al., 1992 and unpublished; Dinet and Vivier, 1977; Thiel, 1975). Vanreusel et al. (1992) explained these low numbers in terms of the low chlorophyll-a content and/or the coarseness of the sediments. In adjacent abyssal regions (areas 9 and 10), Dinet and Vivier (1977) observed a larger variability, which they associated with sedimentological heterogeneity and hydrodynamical disturbance. In these areas, the sediments seem to be unusually coarse and unstable, due to the presence of submarine canyons which elevate current activity (Dinet and Vivier, 1977).

Finally, an obvious decrease in the meiobenthic densities, related to diminishing CPE content with depth, is found in the Porcupine Seabight (from 2000 to $450 \mathrm{ind} / 10 \mathrm{~cm}^{2}$ ) (Pfannkuche, 1985).

Tietjen (1992) described the distribution of metazoan meiofauna of the global Atlantic Ocean by the following logarithmic function of depth: $\mathrm{Y}=6238-710.5 \ln$ depth $(\mathrm{R}=-0.89)$. As shown in Figure 4 this relationship is not found for data of the northeast Atlantic. This function is only approached (Figure 6; $\mathrm{Y}=5837-666 \ln$ depth, $\mathrm{R}^{2}=0896$ ) when mainly shallow areas which were characterized by much lower densities than expected (as discussed above) because of hydrodynamical processes (areas 17, 20, 21, 26), their off-shore location (areas 24, 25) or sedimentological characteristics (areas 5, 6) are omitted. Tietjen (1992) also considered only four sites shallower than $1000 \mathrm{~m}$ in describing this strong functional relationship.

Nematode densities range from 5 ind $/ 10 \mathrm{~cm}^{2}$ in the Gulf of Biscay (Dinet and Vivier, 1977) to $2382 \mathrm{ind} / 10 \mathrm{~cm}^{2}$ in the Porcupine Seabight (Pfannkuche, 1985). Nematodes represent $80-99 \%$ of the total metazoan abundances and are therefore mainly responsible for the depth-related tendencies found for the metazoans (see Figures 4,6). This is illustrated by Figure 7 which shows a weak negative relationship between nematode densities and water depth. However, excluding the two most shallow areas 5 and 6 at the shelf break of the Bay of Biscay strengthens the relationship $\left(\mathrm{R}^{2}=0.870, \mathrm{Y}=5400-613 \mathrm{ln}\right.$ depth). The exclusion of these two areas can be justified by their exceptional coarse sediment and their shallow location at the shelf break 


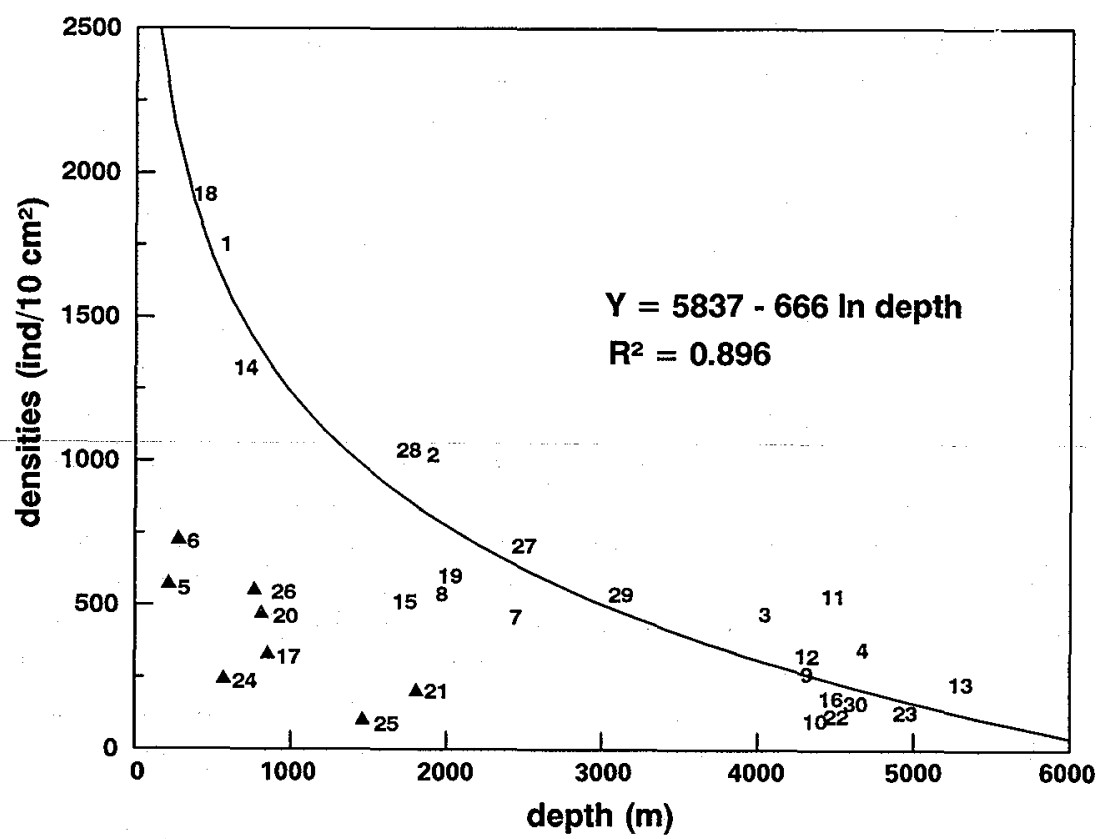

Figure 6 The relationship between mean metazoan densities and mean water depth for each area in the northeast Atlantic. The areas 5, 6, 17, 20,21, 24, 25, 26 are not included in the regression.

Considering smaller geographic regions, nematode densities also decrease with water depth in the Porcupine Seabight, near the coast of Mauretania and to a lesser extent in the Bay of Biscay. In the latter case, densities are low $\left(<1000 \mathrm{ind} / 10 \mathrm{~cm}^{2}\right)$ at the shelf break and on the upper slope (Figure 8).

Copepods represent the second major metazoan meiobenthic taxon after the nematodes. Their densities vary from 166 individuals $/ 10 \mathrm{~cm}^{2}$, the highest abundance recorded by Vanreusel and Vincx (unpublished) in the Bay of Biscay, to zero as observed in a few cases by Dinet (unpublished) in some samples from the EUMELI site (areas 28, 29, 30). While the general distribution pattern exhibits a decrease with increasing depths (Figures 9 and 10), high densities of copepods $\left(50-60 \mathrm{ind} / 10 \mathrm{~cm}^{2}\right)$, are recorded in the northwestern abyssal zone. However, low abundances are encountered in all zones and at all depths (Figure 9), probably because of the patchy distribution of copepods (Dinet et al., 1985).

The decrease in copepod densities with water depth within smaller geographic areas is pronounced in the Bay of Biscay (Figure 10). In the Porcupine area densities are higher on the lower (area 2) than on the 


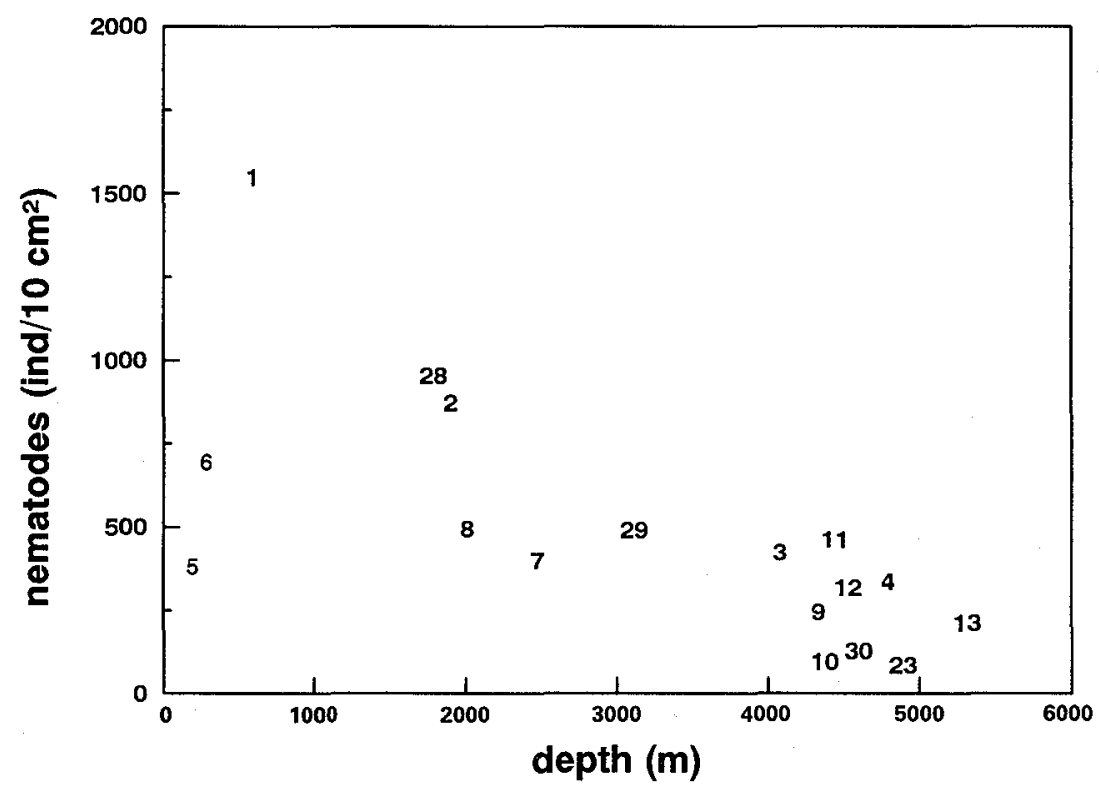

Figure 7 The relationship between mean nematode density and mean water depth for each area (cf. Table 1) in the northeast Atlantic.

upper slope (area 1). In the upwelling near Mauretania, the copepods show low densities indicating another response than that of the nematodes, as indicated by their overall low densities in this area.

The densities of all other numerically important meiobenthic taxa are given in Table 2

Polychaetes were found at all sites where a detailed meiobenthos investigation was carried out. Densities range from 1 to $45 \mathrm{ind} / 10 \mathrm{~cm}^{2}$ and a decreasing trend in numbers is apparent with increasing water depth (below $2000 \mathrm{~m}$ water depth, densities are always lower than 20 ind/ $10 \mathrm{~cm}^{2}$ ). Turbellaria are recorded from the southern areas 28,29 and 30 with densities ranging from 1 to $45 \mathrm{ind} / 10 \mathrm{~cm}^{2}$ (Dinet, unpublished) and from the Bay of Biscay (Vanreusel et al., 1992) (areas 5 and 6) with densities up to $188 \mathrm{ind} / 10 \mathrm{~cm}^{2}$. The soft bodied nature of the turbellaria presents practical problems so that a significant bias in the recorded density values is likely between studies. Oligochaetes and hydrozoans were only recorded from the shelf break area in the Bay of Biscay (area 5). Ostracods are common in deep-sea sediments and show a decreasing trend with increasing water depth. Gastrotrichs are only relatively abundant in the Porcupine Seabight and in the lower stations of the Bay of Biscay. Kinorhynchs are frequently found, albeit in low numbers. 


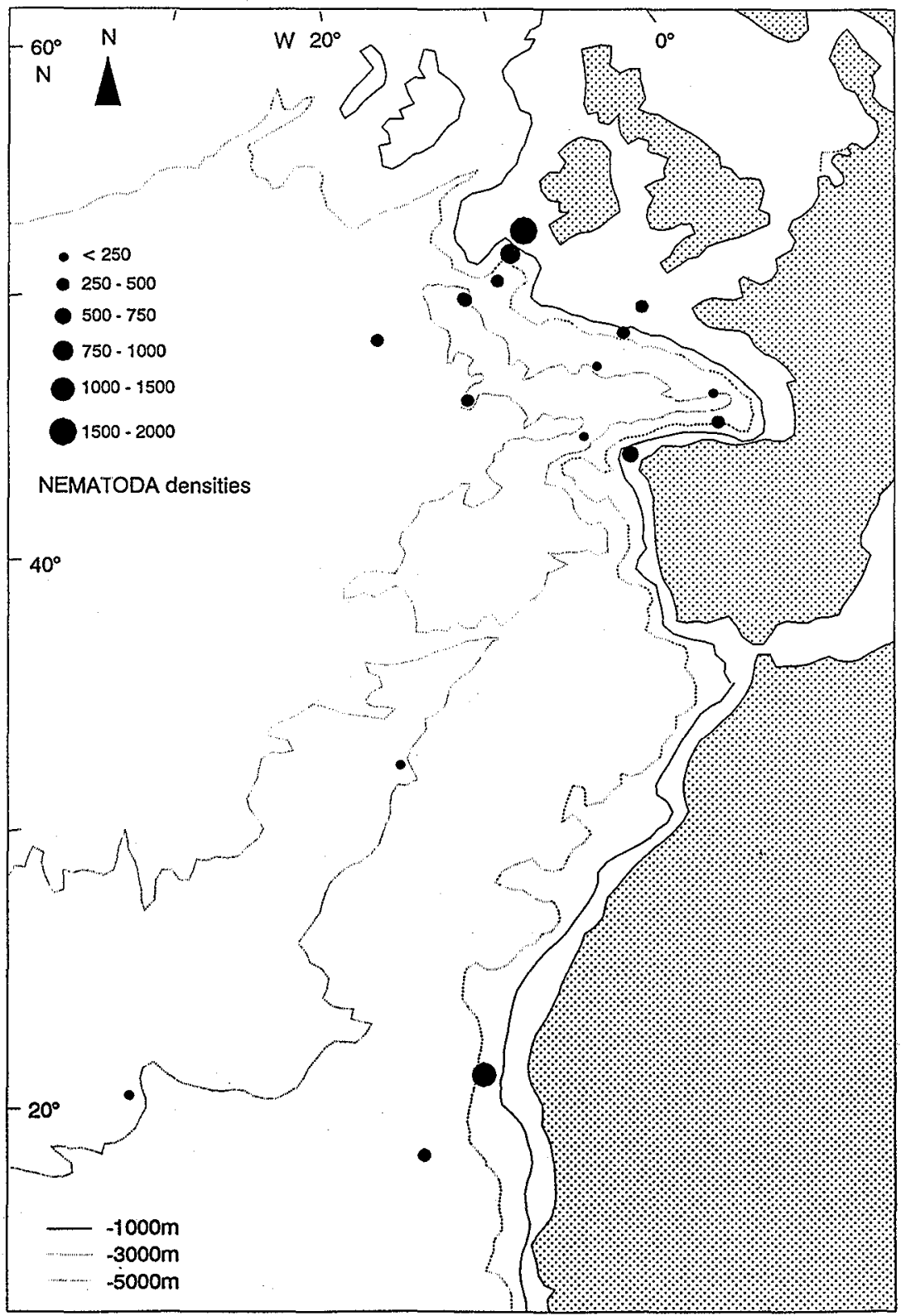

Figure 8 Map of the northeast Atlantic showing mean nematode density for each area (as defined in Table 1) (ind $/ 10 \mathrm{~cm}^{2}$ ). 


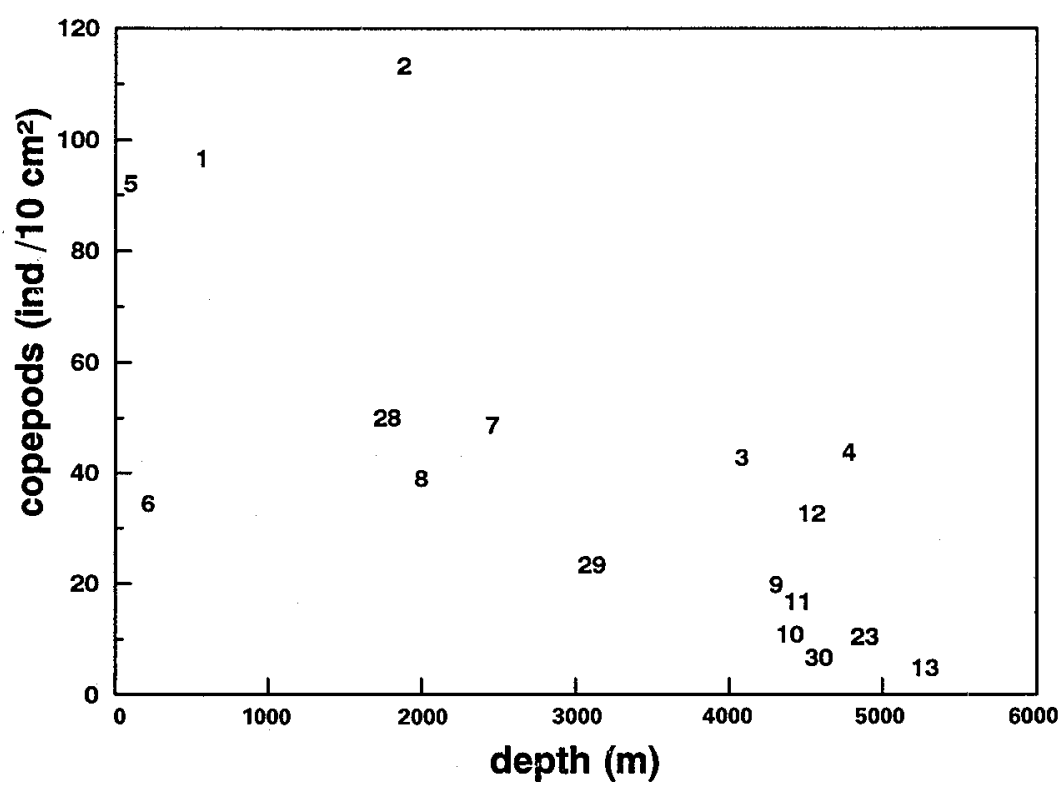

Figure 9 The relationship between mean copepod density and mean water depth for each area (cf. Table 1) in the northeast Atlantic.

Tardigrades, amphipods, loricifers, halacarids, isopods, bivalves and tanaids occur sporadically and always in very low numbers.

Protozoans, in particular foraminifera, are very successful in the deep sea. They often constitute at least $50 \%$ of deep-sea meiobenthic assemblages (Gooday, 1986a; Gooday and Lambshead, 1989; Pfannkuche, 1993b). Abundance data for specimens stained with Rose Bengal are available for seven areas in the northeast Atlantic (Table 2). In relation to water depth, the highest densities are found at the shallowest sites (1000-2000 ind $\left./ 10 \mathrm{~cm}^{2}\right)$, while the lowest densities are found in abyssal areas, although relatively high numbers have been recorded from $4500 \mathrm{~m}$ depth $\left(1000 \mathrm{ind} / 10 \mathrm{~cm}^{2}\right)$ (Figure 11). Data on the local distribution of foraminifera are only available from the Porcupine Seabight (Figure 12). At the deepest sites $(<4500 \mathrm{~m})$ densities are somewhat lower $\left(500-1000 \mathrm{ind} / 10 \mathrm{~cm}^{2}\right)$ than on the slope $\left(1000-3000 \mathrm{ind} / 10 \mathrm{~cm}^{2}\right)$.

\subsubsection{Faunal Composition}

To compare the composition of the metazoan meiobenthos from different deep-sea areas in the northeast Atlantic, we have concentrated on the most abundant taxa, for example nematodes, harpacticoid copepods 


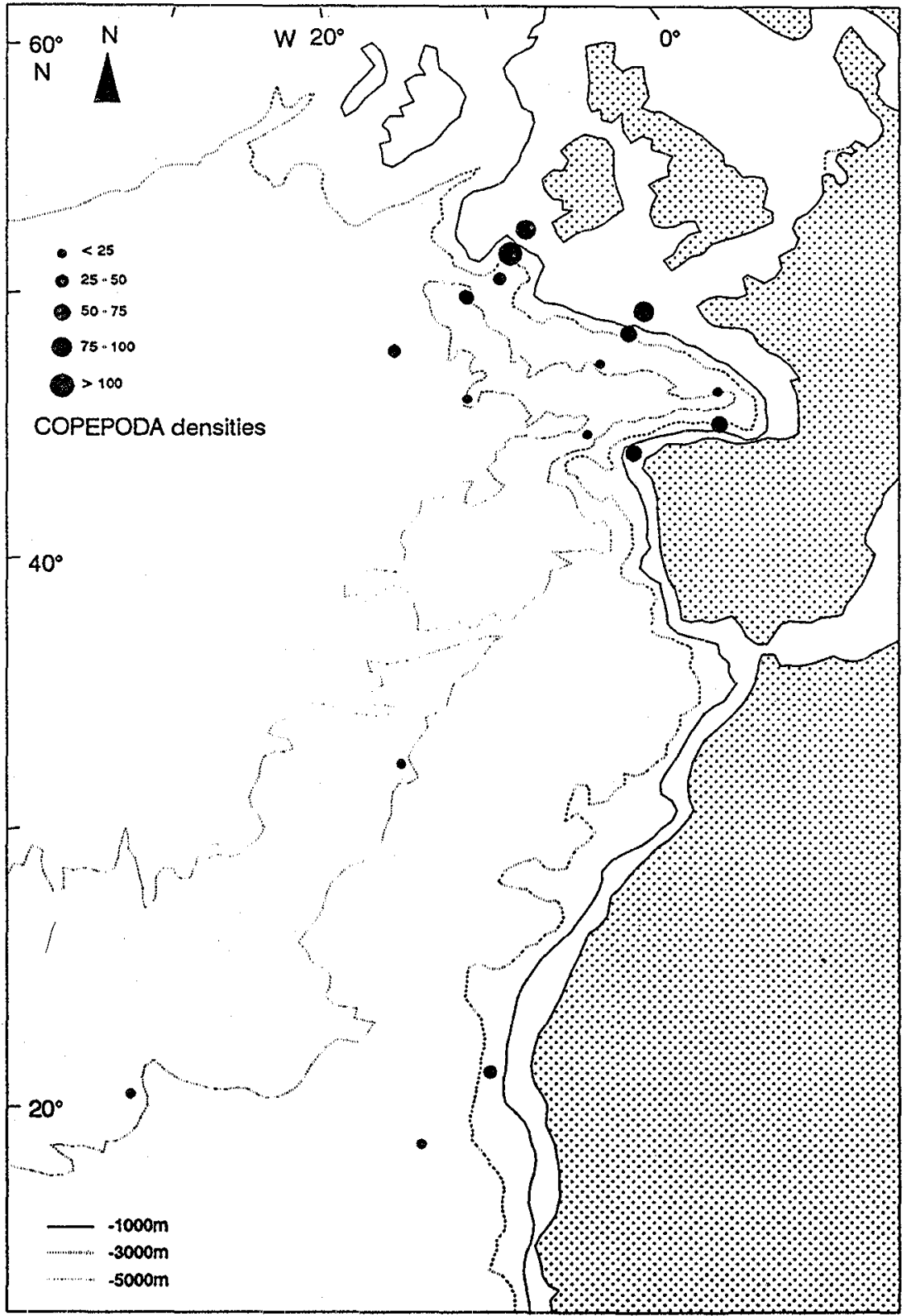

Figure 10 Map of the northeast Atlantic showing mean copepod density for each area (ind $/ 10 \mathrm{~cm}^{2}$ ). 


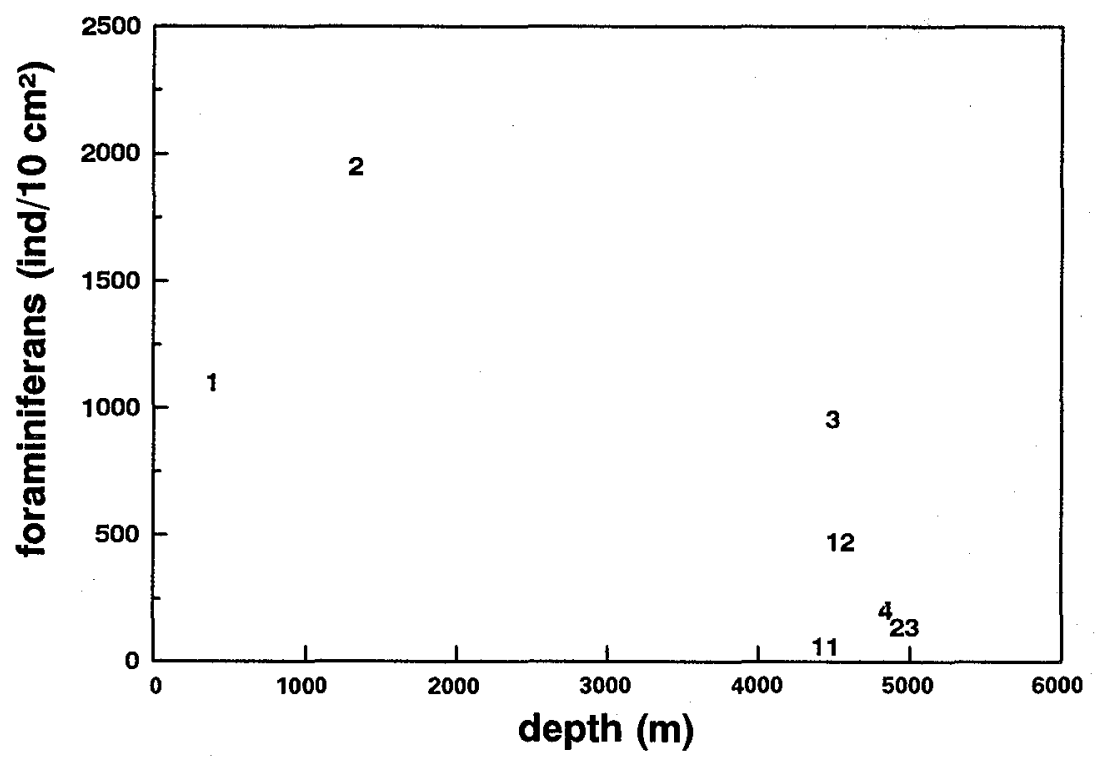

Figure 11 The relationship between mean foraminifera density and mean water depth for each area (cf. Table 1) in the northeast Atlantic.

(including nauplii) and polychaetes, and combined all the other taxa, which appear only occasionally, into one category ("others"). Nematodes clearly dominate the metazoan meiobenthic community: on average, more than $80 \%$ (maximum 99\%) of the metazoan meiobenthos are nematodes. Copepods and nauplii together constitute the second most important group, representing up to $10 \%$ of the metazoans. Polychaetes and other taxa (mainly ostracods, kinorhynchs, turbellaria, gastropods and bivalves) appear in almost all water depths, but are most abundant on the shelf and the continental slope.

In contrast to the comparatively obvious influence of depth-related factors in determining the densities of meiobenthic taxa within the study area, global trends in the percentage composition of the fauna are not so apparent. Nevertheless, the evaluation of all meiobenthic data available from the northeast Atlantic shows changes in taxonomic composition with increasing water depth. Box plots illustrate the trends for different taxa (Figure $13 \mathrm{a}-\mathrm{d}$ ). In these figures all 17 areas from which composition data are available are arranged in 11 depth classes.

The relative abundance of nematodes generally increases with depth, and correspondingly the percentage composition of all other taxa decreases with depth. ANOVA statistics (based on arcsine transformed percentage data) confirm significant differences $(p<0.05)$ between mean 


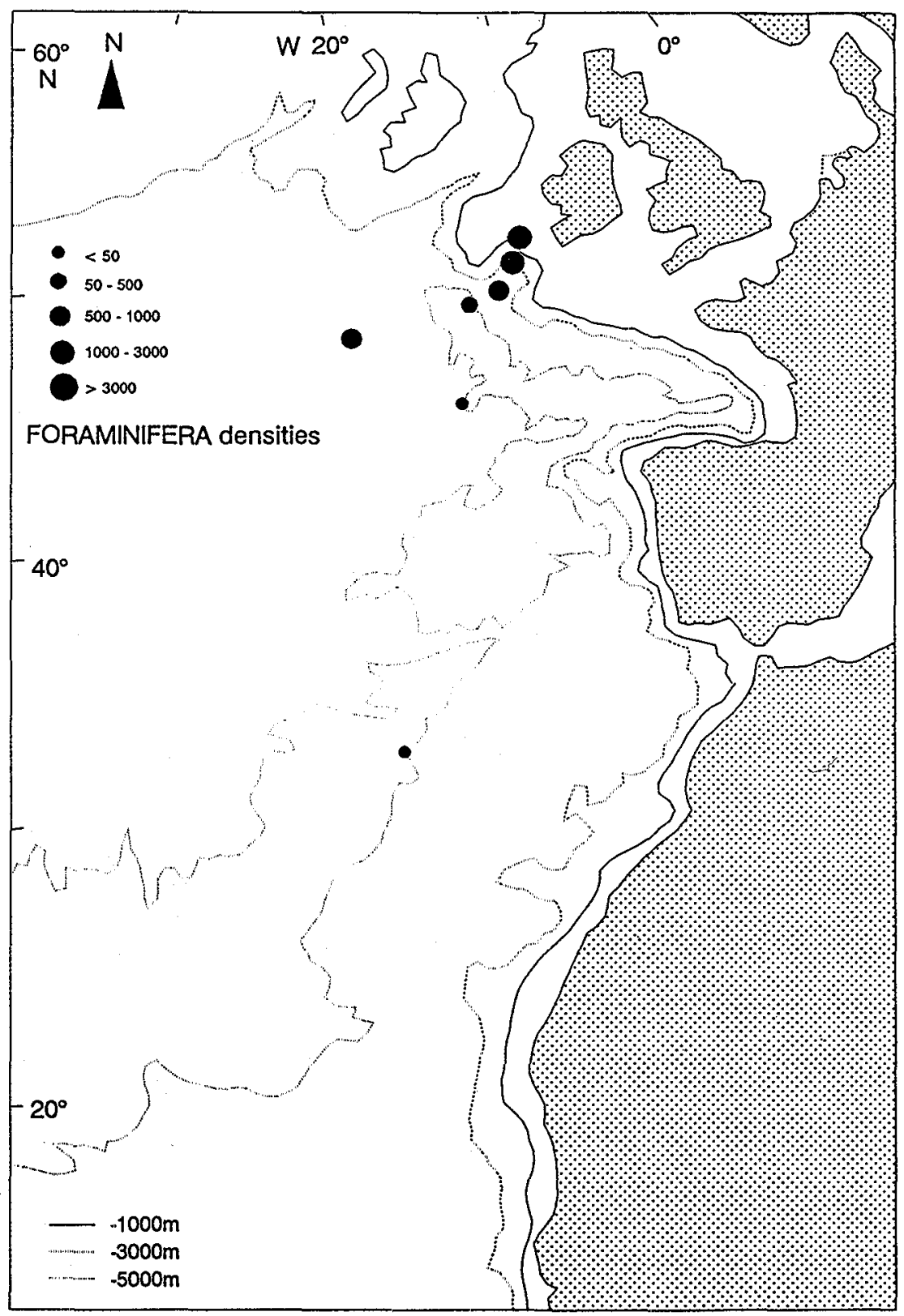

Figure 12 Map of the northeast Atlantic showing mean foraminifera density for each area (ind $\left./ 10 \mathrm{~cm}^{2}\right)$. 
(a)

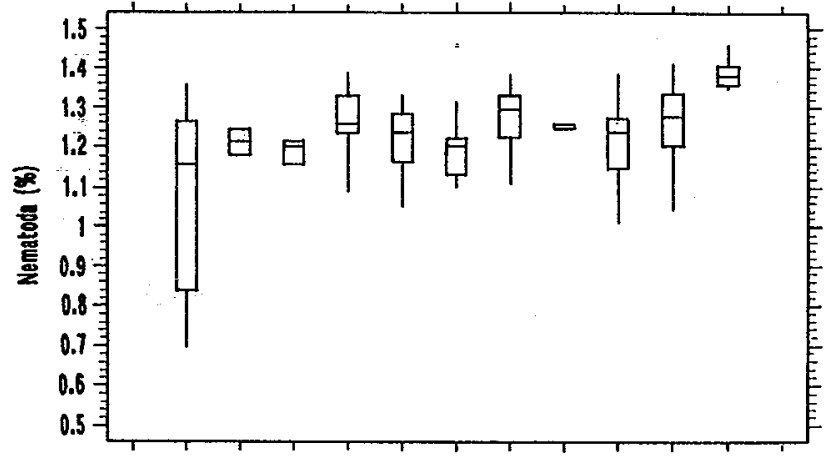

$500 \cdot 1000 \quad 150020002500300035004000450050005500$

(c)

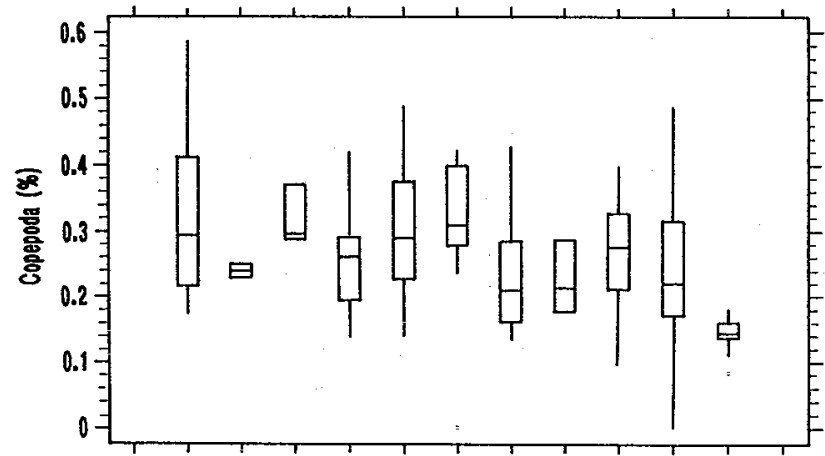

$500 \quad 1000 \quad 1500 \quad 200025003000 \quad 3500 \quad 40004500 \quad 5000 \quad 5500$ Water depth (m) (b)

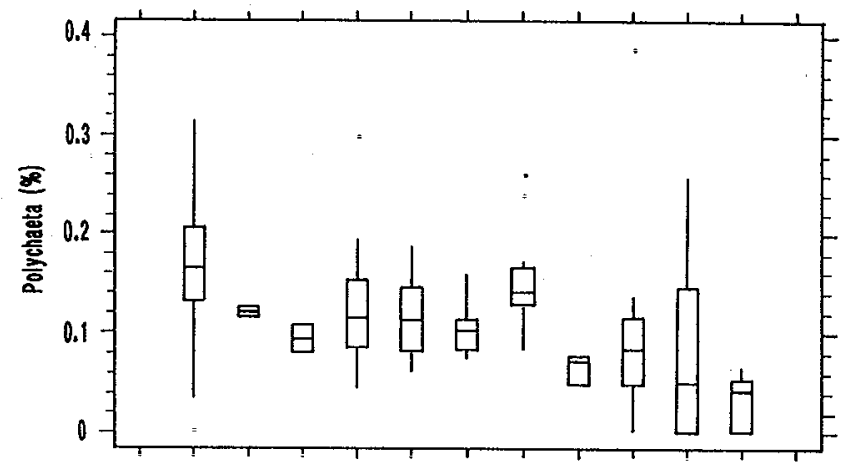

$500 \quad 1000 \quad 1500 \quad 2000 \quad 2500 \quad 3000 \quad 3500 \quad 400045005000 \quad 5500$
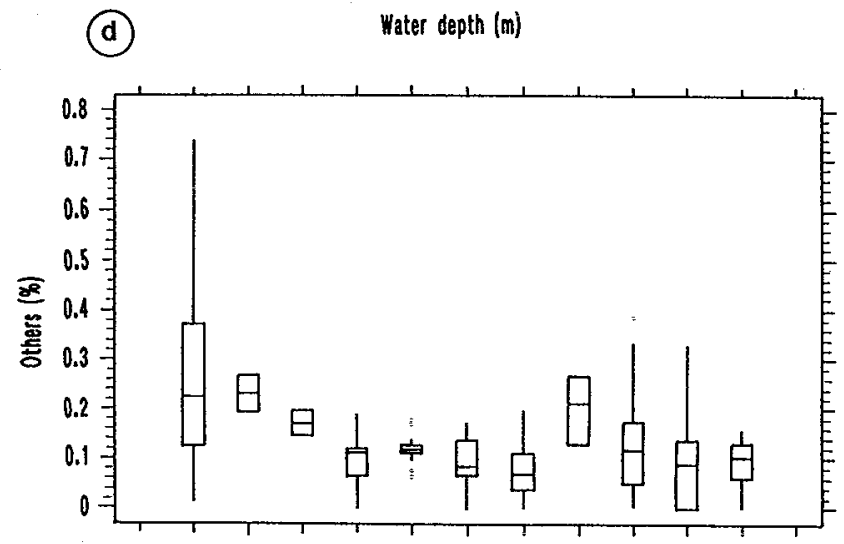

$500 \quad 1000 \quad 1500 \quad 2000 \quad 2500 \quad 3000 \quad 3500 \quad 4000 \quad 4500 \quad 5000 \quad 5500$ Water depth (m)

Figure 13 Box plots showing median values, upper and lower quartiles and 10 and $90 \%$ values of the relative abundances (arcsine-transformation) of various taxa in different areas. The areas are arranged according to water depth. 
nematode percentages on the shelf $(75.1 \% \pm 19.2 \%)$ and at the deepest stations below $5000 \mathrm{~m}(96.5 \% \pm 1.2 \%)$. Significant decreases $(p<0.05)$ in relative abundances, from shallow to deep water, were found for polychaetes $(3.2 \% \pm 2.7 \%$ to $0.2 \% \pm 0.2 \%)$, copepods $(11.2 \% \pm 8.5 \%$ to $2.2 \% \pm 0.7 \%)$, and "others" $(10.6 \% \pm 13.6 \%$ to $1.1 \% \pm 0.8 \%)$. The highest coefficients of variation, representing variability within areas, occurred at shallow stations (128.3\% for "others"), and the lowest variation was found for nematodes from the deepest stations. Also, within smaller geographical areas, most depth transects investigated in the northeast Atlantic are characterized by an increasing relative abundance of nematodes with depth (Thiel, 1972b; Dinet and Vivier, 1977; Pfannkuche, 1985).

Carney et al. (1983) described three different types of depth-associated factors controlling the zonation of the benthos over continental margins. The first includes gradients of physiologically important parameters such as temperature, salinity, oxygen concentration and hydrostatic pressure. The greatest vertical changes in these factors occur within the top $1000 \mathrm{~m}$ in the oceans. Therefore, their effect on zonation should be largely restricted to those depths.

The second group includes factors that change qualitatively with bathymetric depth, such as the transition from coarser to finer sediments. Sediment granulometry plays an important role in faunal zonation on continental shelves (Gray, 1974, and references cited therein). In most deep-sea areas, however, granulometric parameters are more uniform and do not appear to affect the large-scale distribution of the meiobenthos (Thiel, 1983).

The third type of factor controlling faunal zonation consists of those resources that change in availability with depth. A decrease in available food (quantitative and qualitative input of detritus to the benthos) or an increase in available space (generally lower abundances in deeper regions) with water depth are examples of the third type.

While availability of interstitial space probably would not affect smaller benthic size groups (such as the meiobenthos) significantly, the decisive influence of the quantitative and qualitative food supply on benthos is clear.

For the smallest benthic organisms such as protozoans (mainly foraminifera) it is clear that they are well adapted, by their short generation times and opportunistic feeding habits, to respond quickly to the variable food input at abyssal depths (Linke, 1992; Pfannkuche, 1993b; Altenbach, 1993). For comparable reasons small nematode species possibly might be well able to cope with the temporary availability of food. Besides, since it is generally accepted that a major part of the carbon flow in the deep sea is channelled through the bacteria (Lochte, 1992), those 
organisms that feed on bacteria will be favoured. These organisms include most of the dominant nematode species.

\subsection{Latitudinal Trends}

\subsubsection{Faunal Densities}

Large-scale latitudinal trends are also important in characterizing the meiobenthos. In Figure 14 all areas are arranged according to their latitude (from south $(\mathrm{S})$ to north $(\mathrm{N})$ ), within three different depth zones; the northern abyssal sites $(>3000 \mathrm{~m})$ are ordered from west $(\mathrm{W})$ to east (E). These arrangements illustrate weak geographic gradients of the densities of the metazoan meiobenthos which, to some extent, are related to the surface primary productivity.

Among the deepest stations $(>3000 \mathrm{~m})$, densities were higher in the northwest (areas 11, 12, 4 and 3-the BIOTRANS area, the DORA area and the Porcupine Abyssal Plain) with $300-500 \mathrm{ind} / 10 \mathrm{~cm}^{2}$, than in the south (areas 30, 22, 23 and 16-the EUMELI area, off the NW African coast, the Madeira Abyssal Plain and off the Portuguese coast) with less than $250 \mathrm{ind} / 10 \mathrm{~cm}^{2}$. An exception to this increasing south to north trend is the most southernly location, area 29 in the upwelling zone near the coast of Mauretania, which is characterized by high abundances According to the surface primary productivity map for the Atlantic Ocean (Figure 3), the upwelling area off Mauretania has a primary productivity of more than $150 \mathrm{~g} \mathrm{C} \mathrm{m}^{-2}$ year $^{-1}$, the northern sites are situated between the 60 and 125 isolines, while at the other southern sites surface productivity varies between 45 and $90 \mathrm{~g} \mathrm{C} \mathrm{m}^{-2}$ year $^{-1}$.

From the northwestern areas 3, 4, 11 and 12, towards the Iberian Sea and the Gulf of Biscay in the northeast (areas 9,10 and 13), densities also decrease, although not significantly. Sedimentological and hydrodynamical processes may explain the low abundances in the east (see above). The observed trend, however, is opposite to the increase in surface productivity. Furthermore, at the Porcupine Abyssal Plain (area 4), the DORA (area 11), and the BIOTRANS sites (area 12), large amounts of phytodetritus reach the seafloor within a relatively short period after the spring plankton bloom (Thiel et al., 1989-1990; Rice et al., 1991). This is likely to represent an important food input for the meiobenthos (Billett $e t$ al., 1983; Gooday, 1988).

A similar south to north trend is found for the $1000-3000 \mathrm{~m}$ areas (Figure 14): densities were lowest on the Great Meteor seamount and off Morocco (areas 21 and 25), where the surface productivity varies between 45 and $90 \mathrm{~g} \mathrm{C} \mathrm{m}^{-2}$ year ${ }^{-1}$. They were somewhat higher off Gibraltar, the 


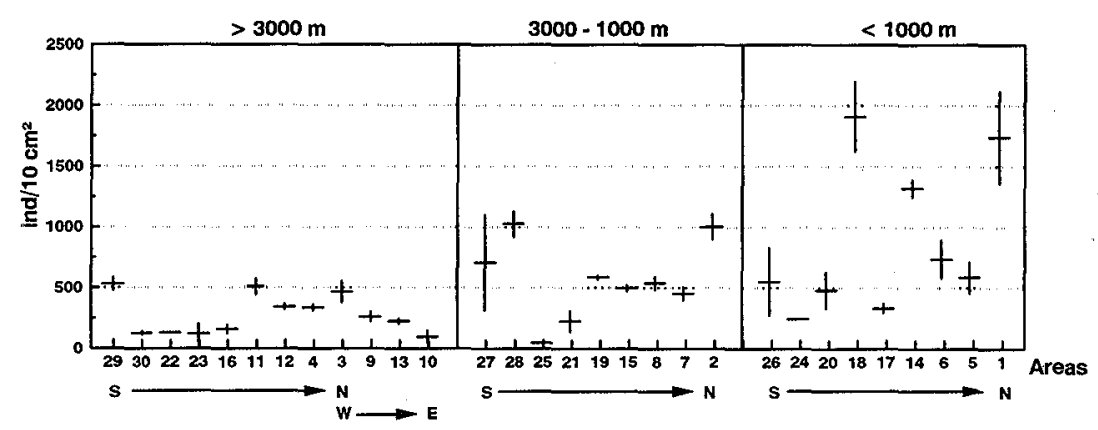

Figure 14 The mean metazoan densities ( \pm SE) for each area in the northeast Atlantic. The areas are grouped into depth zones and arranged by latitude (N, North; S, South) and/or longitude (W, West; E, East).

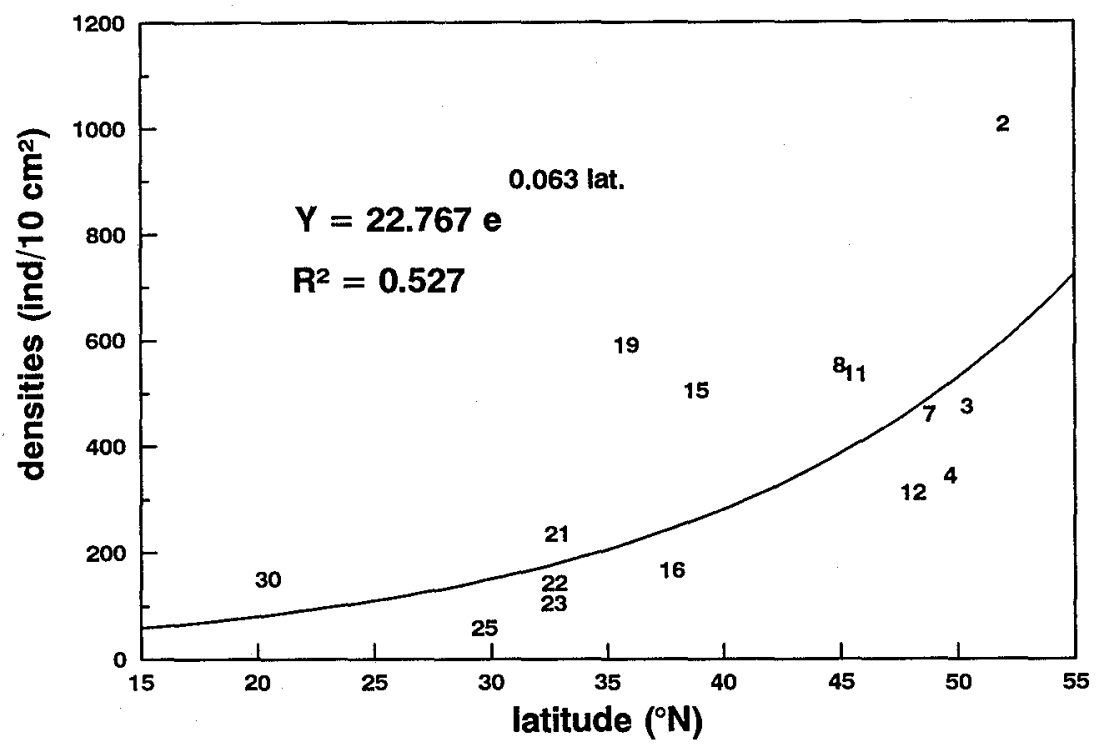

Figure 15 The relationship between mean metazoan density and mean latitude for all areas in the northeast Atlantic deeper than $1000 \mathrm{~m}$, except areas 27, 28 and 29 in the upwelling near Mauretania, and the northeastern areas 13, 9 and 10 off the Bay of Biscay. 


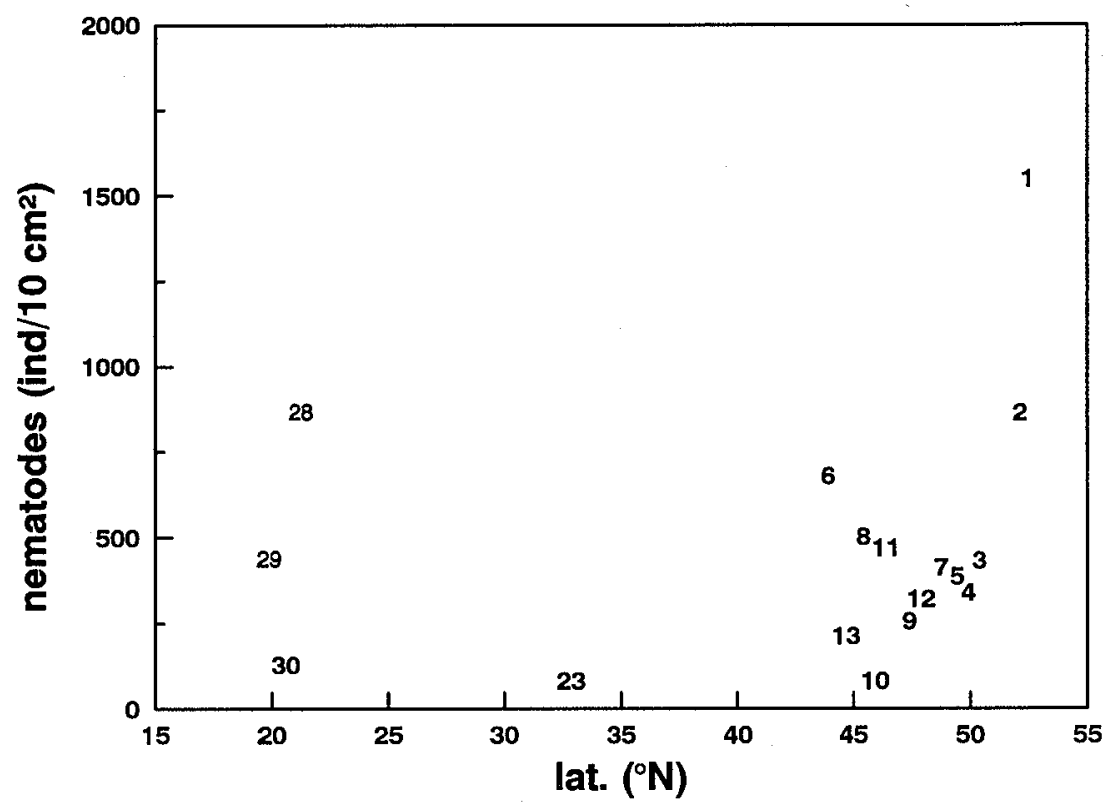

Figure 16 The relationship between mean nematode density and mean latitude of each area in the northeast Atlantic.

Portuguese coast and the Bay of Biscay (areas 7, 8, 15 and 19), situated between the isolines of 60 and $125 \mathrm{~g} \mathrm{C} \mathrm{m}^{-2}$ year $^{-1}$ and highest in the Porcupine Seabight between the isolines of 90 and $125 \mathrm{~g} \mathrm{C} \mathrm{m}^{-2}$ year $^{-1}$ (area 2). Off Mauretania (areas 27 and 28) meiobenthos was again exceptionally abundant due to upwelling (productivity $>150 \mathrm{~g} \mathrm{C} \mathrm{m}^{-2}$ year $^{-1}$ ).

On the upper slope and around the shelf break $(<1000 \mathrm{~m})$ the same geographic tendency is no longer evident. Meiobenthos is most abundant in the Porcupine Seabight, off the North African coast and to a lesser extent near the Portuguese coast (areas 1, 14 and 18). Densities are lowest on the Great Meteor seamount (area 24) and the remaining sites having intermediate abundances (areas 26, 20, 17,6 and 5).

A plot of the mean densities of all areas deeper than $1000 \mathrm{~m}$ (Figure 15), with the exception of those in the southern upwelling zone near Mauretania and the northwestern sites near the Bay of Biscay, as a function of their latitude, summarizes these weak south-north gradients.

Nematodes show a similar relationship with latitude. Again densities are much higher in the northwest in comparison to the south, with the exception of two upwelling sites near Mauretania (areas 28 and 29) (Figure 16). The same pattern applies to mean copepod densities, 


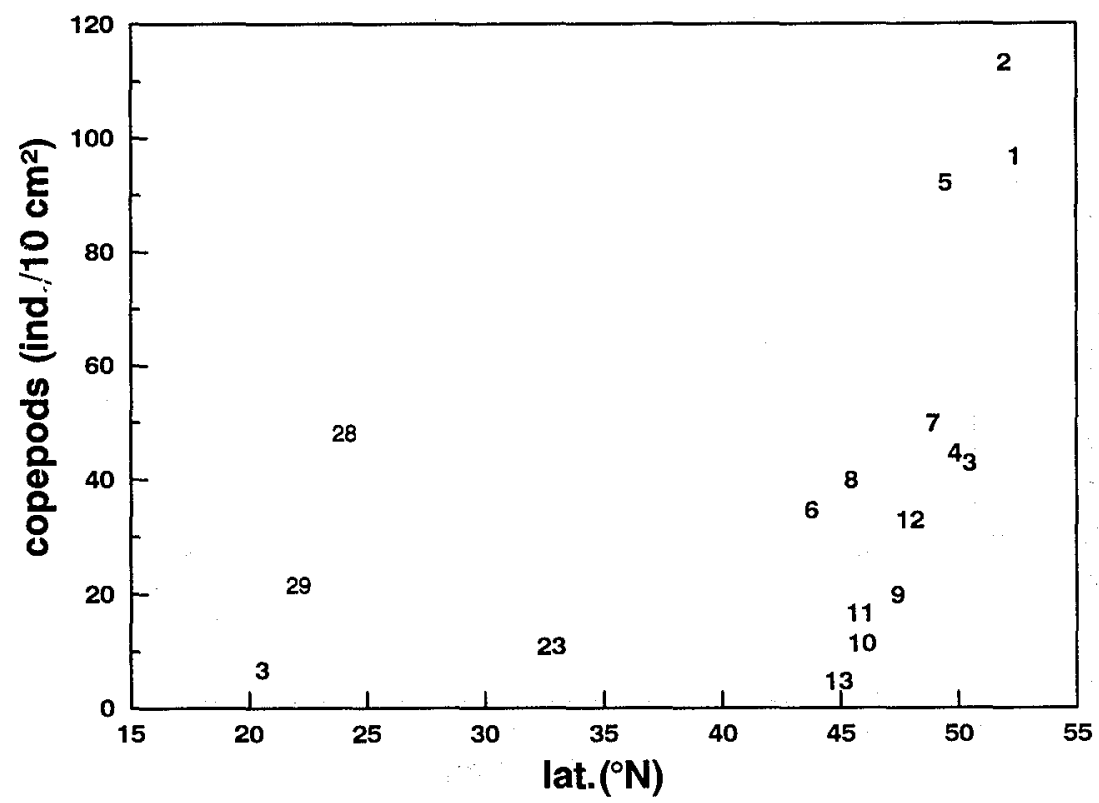

Figure 17 The relationship between mean copepod density and mean latitude for each area in the northeast Atlantic.

although abundances are much lower $\left(20 \mathrm{ind} / 10 \mathrm{~cm}^{2}\right)$ over the total gradient (Figure 17). These latitudinal trends are presumably related to the higher productivity of the northern areas.

Figure 18 illustrates latitudinal variation for the foraminifera, although note that relatively few data are available from the south. Densities reach $1000-2000 \mathrm{ind} / 10 \mathrm{~cm}^{2}$ at bathyal depths in the Porcupine Seabight (areas 1 and 2) and are almost as high (956 ind $10 \mathrm{~cm}^{2}$ ) on the Porcupine Abyssal Plain near the mouth of the Porcupine Seabight (area 3). Values are variable but lower in area 4 on the Porcupine Abyssal Plain (102-283 ind $/ 10 \mathrm{~cm}^{2}$ ) (Gooday and Lambshead, 1989, not included in Table 2), and at the BIOTRANS site (area $12 ; 196-864 \mathrm{ind} / 10 \mathrm{~cm}^{2}$ ). The lowest values $\left(<50 / 10 \mathrm{~cm}^{2}\right)$ were recorded from area 11 (DORA) and area 23 (Madeira Abyssal Plain).

\subsubsection{Faunal Composition}

Quantitative and qualitative aspects of food availability are important in controlling the composition of the benthos, enabling a taxonomically richer community to develop in areas with a higher input. Changes in 


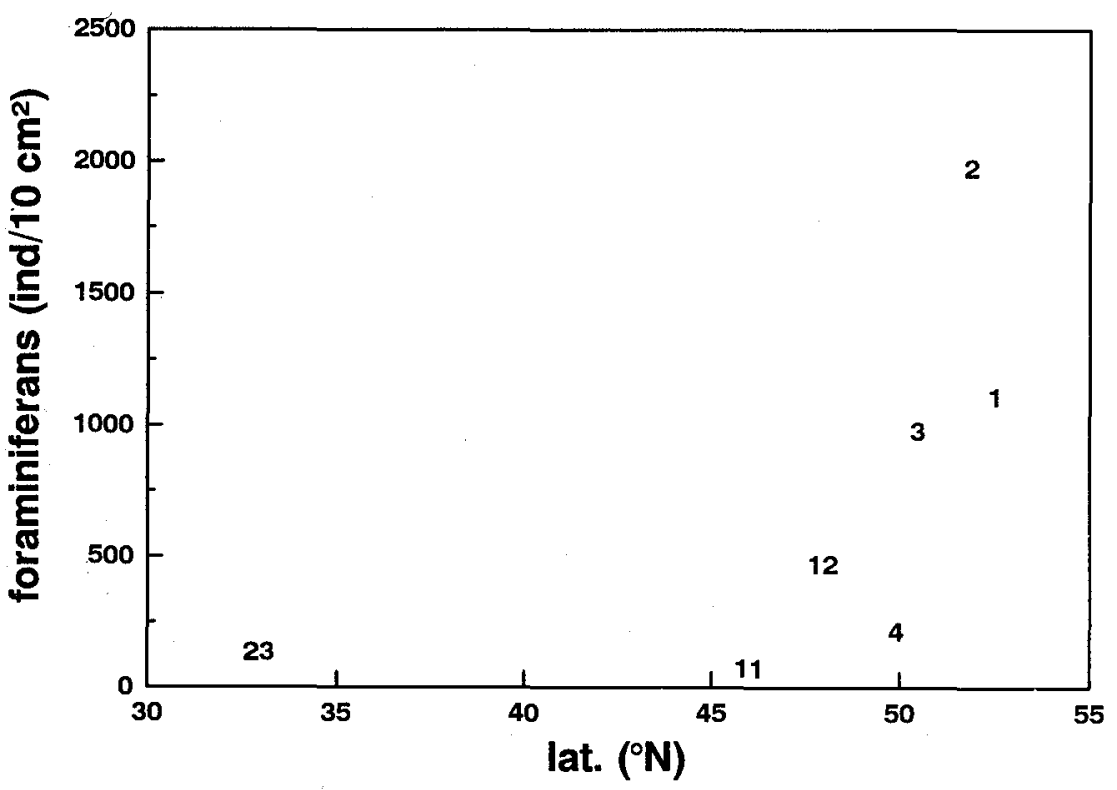

Figure 18 The relationship between mean foraminifera density and mean latitude of each area in the northeast Atlantic.

taxonomic composition attributable to this factor should be detectable in the northeast Atlantic. The greater depth of winter mixing in higher latitudes facilitates higher productivity in those regions, whereas at the southern edge of our area of interest, there is increased surface productivity associated with the coastal upwelling off NW Africa. In both cases this may affect the composition of the meiobenthos.

Figure 19a-d shows median percentages of different taxa with increasing latitude (note that some areas have been combined according to their latitude, namely areas 8 and 11 at $46^{\circ} \mathrm{N}$, areas 7 and 13 at $49^{\circ} \mathrm{N}$, and areas 3 and 4 at $51^{\circ} \mathrm{N}$ ).

The percentage of copepods and particularly polychaetes is low around $45^{\circ} \mathrm{N}$ and significantly (ANOVA $p<0.05$ ) higher further to the south and to the north. The relative abundance of nematodes shows a tendency for higher values at lower latitudes and lower values at higher latitudes. The reverse is true for the group of other taxa, where slightly increased percentages in higher latitudes were observed. However, ANOVA indicated no significant differences in the relative abundances of nematodes or "others" with latitude. The results for $50^{\circ} \mathrm{N}$ represent shallow water stations on the shelf break area in the Bay of Biscay exclusively 
(a)

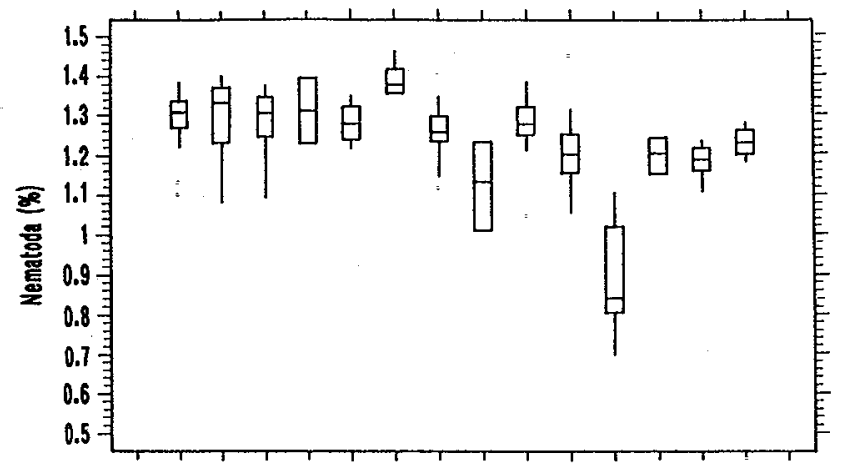

$\begin{array}{llllllllllllll}19 & 21 & 22 & 33 & 44 & 45 & 46 & 47 & 48 & 49 & 50 & 51 & 52 & 53\end{array}$

(C)

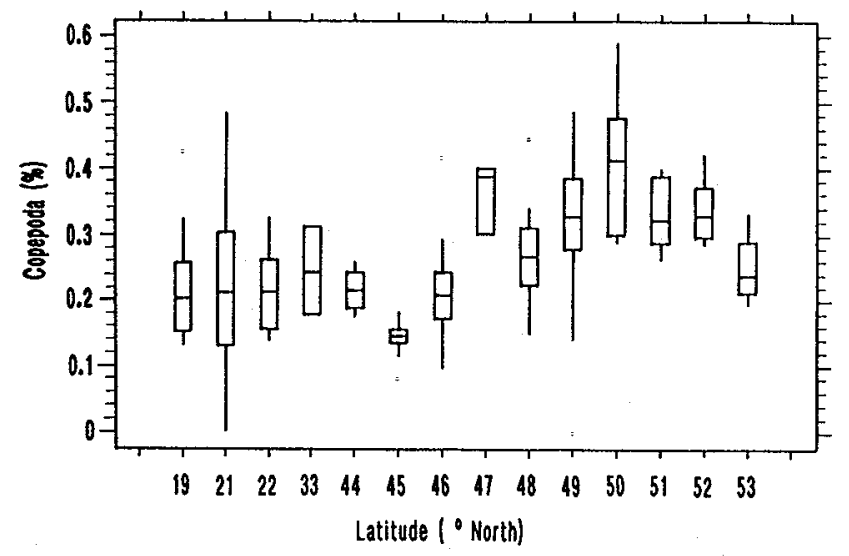

(b)
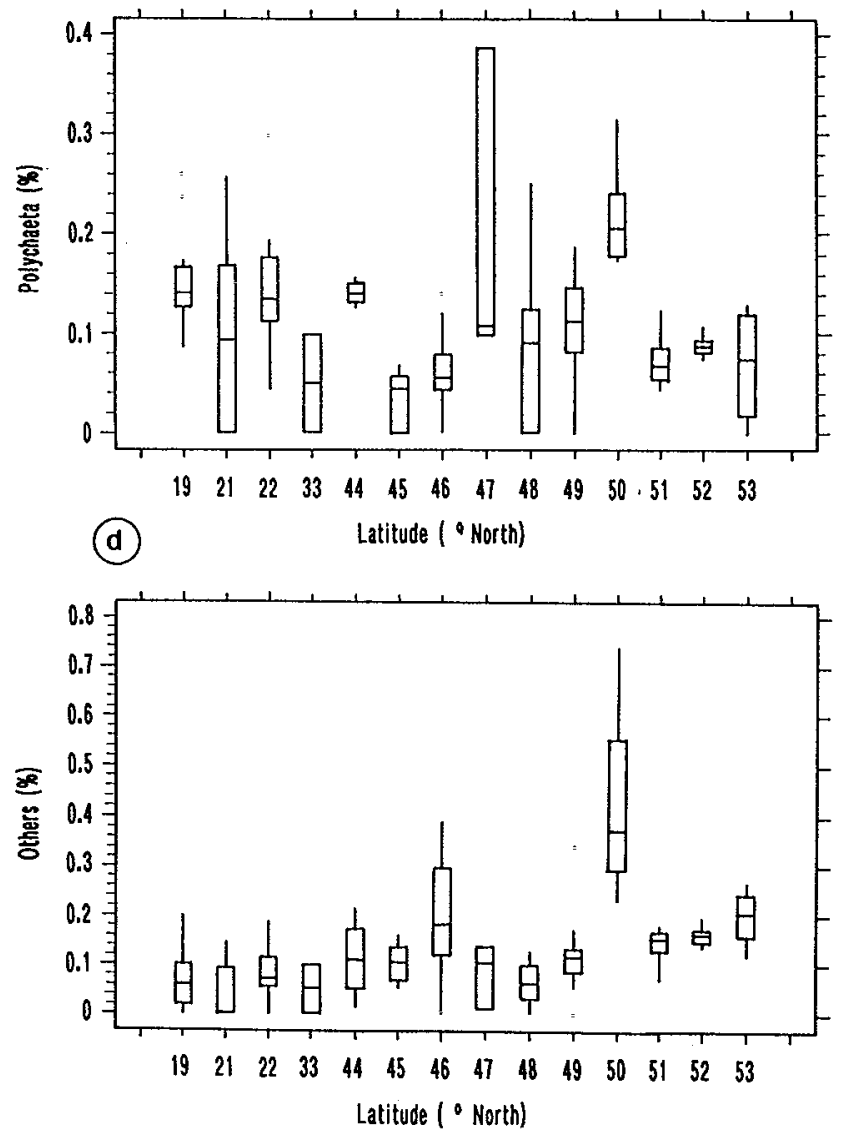

Figure 19 Box plots showing median values, upper and lower quartiles and 10 and $90 \%$ values of the relative abundances (arcsine-transformation) of various taxa in different areas. The areas are arranged according to latitude. 
(area 5) (Vanreusel and Vincx, unpublished) and should be regarded separately.

\subsection{Multivariate Analysis}

The various depth and latitude (primary production) related densities trends for different taxa in the northeast Atlantic, as illustrated above, are confirmed overall by a multivariate analysis. This analysis has been performed for the 17 areas from which taxon composition data are available: areas $1-13$, area 23 , areas $28-30$; the replicate density data (Table 2) were summarized to geometric mean values before analysis (Figures 20 and 21).

The abundance of each taxon examined shows a significant negative rank correlation with depth (nematodes, $p<0.002$; harpacticoids, $p<0.01$; polychaetes, $p<0.002$; combined other taxa, $p<0.002$ ). When variations in the abundance of these taxa are analysed simultaneously in a multivariate ordination (non-metric multidimensional scaling, using rootroot transformation of abundances and the Bray-Curtis similarity measure) the strongest trend again is related to depth; rank correlation of the multidimensional scaling (MDS) $x$-coordinate with depth is highly significant $(p<0.002)$.

Water depth is itself unlikely to be the causal factor, but rather a suite of other factors linked to water depth is more likely to have produced the observed distributions. Over the large geographical area covered in this analysis the supply of organic matter to the seafloor is likely to be a major factor controlling meiobenthic abundances. In addition to water depth, surface primary production and distance off-shore also play important roles in determining the supply of organic matter to the seafloor. Surface primary production, as estimated from the "Dahlem map" (Berger, 1989), exhibits a significant $(p<0.05)$ rank correlation with the $y$ coordinate of the MDS ordination. The distance of sampling stations from the nearest continental land mass is significantly correlated with both the $x$ - and $y$-coordinates of the ordination. In the present study area, however, distance off-shore can be expected to correlate with both depth and surface primary production.

Multivariate ordination (MDS, arcsine transformation, Bray-Curtis similarity) of the percentage composition data yields few obvious trends (Figures 22 and 23). The distribution of sampling stations in ordination space shows no correlation with depth, surface primary production, or distance off-shore.

Although the multivariate analysis of percentage composition did not reveal any general trend in the data, there is nevertheless a quite 


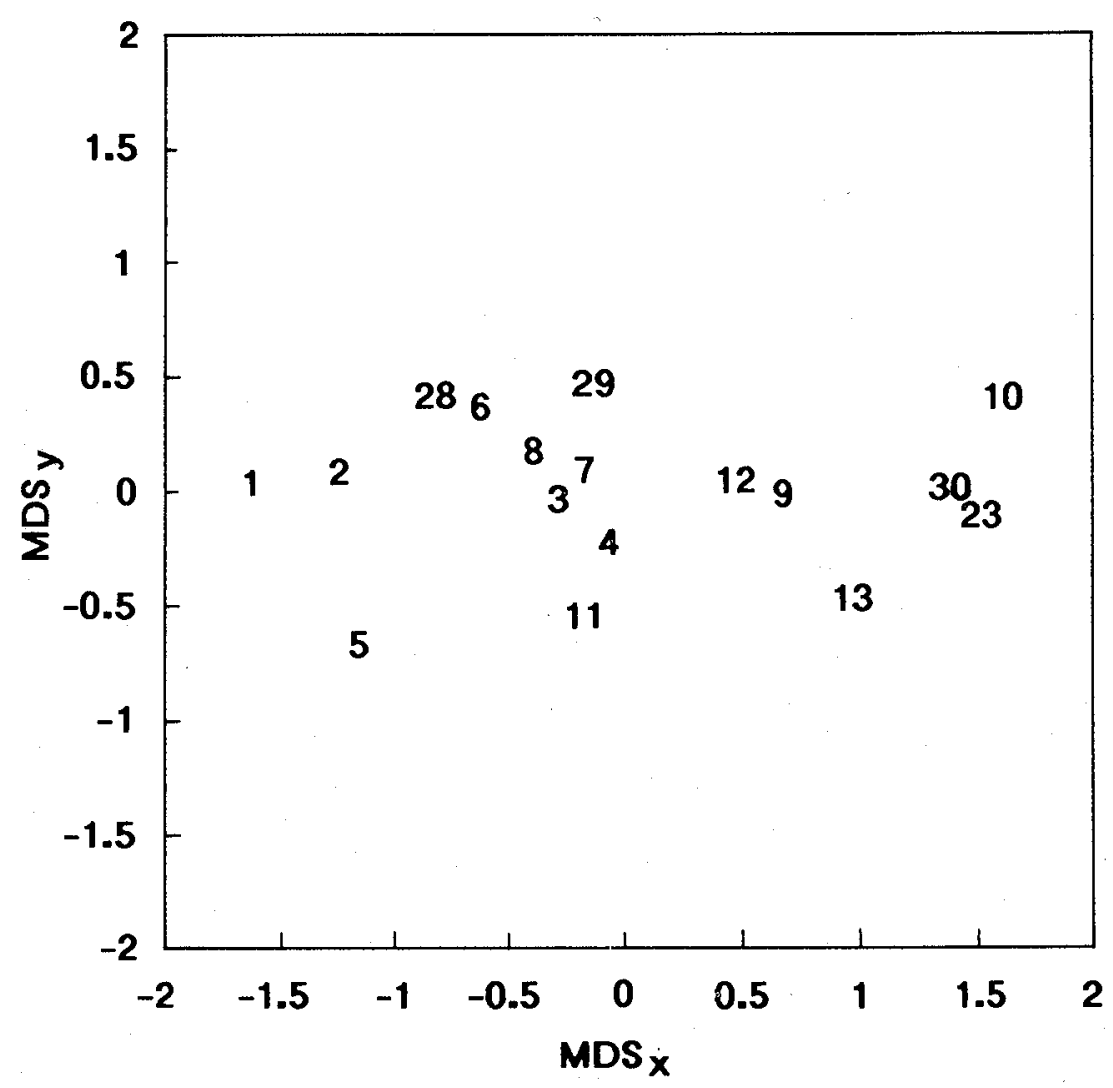

Figure 20 Ordination (MDS) of areas based on abundances of nematodes, copepods, polychaetes and combined other taxa, using root-root transformation.

appreciable variation in the composition of the meiobenthos among sampling stations. This variation is clearly reflected in the relative dominance of the fauna by nematodes or, conversely, the relative importance of all other taxonomic groups. Stations located to the left on the ordination have comparatively low nematode dominance and relatively high proportions of other taxonomic groups (i.e. harpacticoids and polychaetes), as examplified by area 5 (nematodes $62.4 \%$, copepods $16.4 \%$, polychaetes $4.9 \%$, other taxa $16.3 \%$ ). Stations to the right of the ordination are strongly dominated by nematodes with relatively low contributions from other taxa, area 13 for example (nematodes $96.8 \%$, copepods $2.0 \%$, polychaetes $0.2 \%$, other taxa $1.0 \%$ ). The most obvious feature of the ordination is the clear distinction of area 5 from all other 


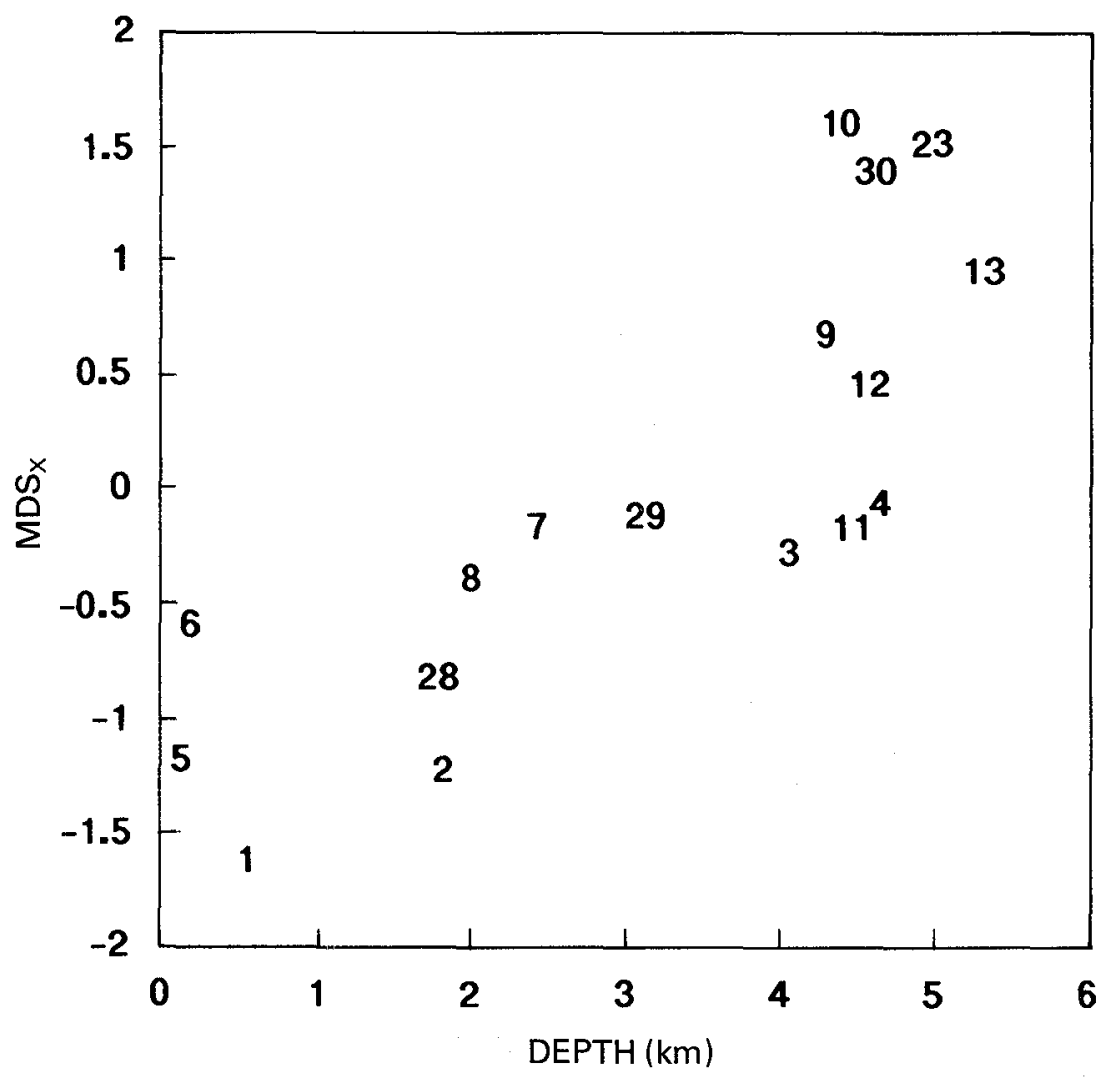

Figure 21 Plot of MDS (from Figure 20) against water depth.

stations. This may be explained by reference to sediment characteristics. Area 5 has medium to coarse sandy sediments while the other stations have rather finer sediments. Sediment grain size is generally regarded as one of the most important factors controlling meiobenthic composition (Coull, 1988). Coarser sediments generally support a more diverse fauna with reduced nematode dominance, as at area 5. Area 5 is also, by far, the shallowest of all the deep-sea areas considered.

With the exception of the distinctiveness of area 5 there appear to be no other obvious trends in the data. Presumably some of the remaining variation is attributable to local environmental conditions and some to biases in the data (e.g. limited replication, variations in sample collection and processing techniques). 


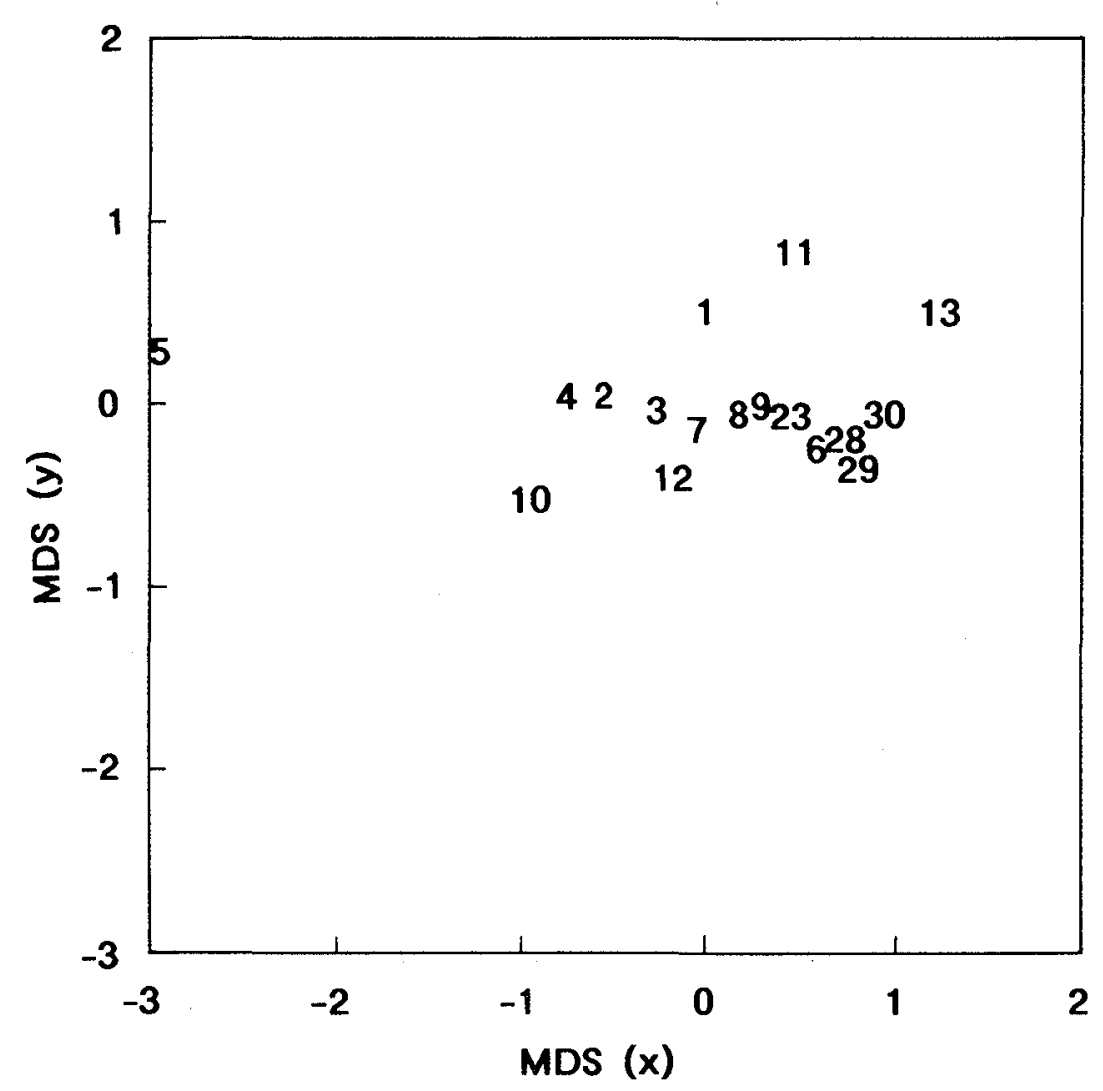

Figure 22 Ordination (MDS) of areas based on percentage composition of nematodes, copepods, polychaetes and combined other taxa, using arcsine transformation.

\subsection{Comparison with Other Regions}

Data on meiobenthic distributions are available for a number of geographical regions other than the northeast Atlantic: the northwest Atlantic (Wigley and McIntyre, 1964; Tietjen, 1971; Coull et al., 1977; Sibuet et al., 1984; Thistle et al., 1985), the Pacific Ocean (Thiel, 1975; Shirayama, 1984a, b; Snider et al., 1984), the Mediterranean and Red Sea (Dinet et al., 1973; Thiel, 1975; Dinet, 1976; Vivier, 1978; Thiel, 1979a, 1983; Thiel et al., 1987; Soetaert et al., 1991a, b; Pfannkuche, 1993a), from the Norwegian Sea (Dinet, 1979), from the Greenland, Norwegian Sea and Indian Ocean (Thiel, 1975; Jensen, 1988), the Arctic Ocean (Pfannkuche and Thiel, 1987), and the southeast Atlantic (Soltwedel, 1993). 


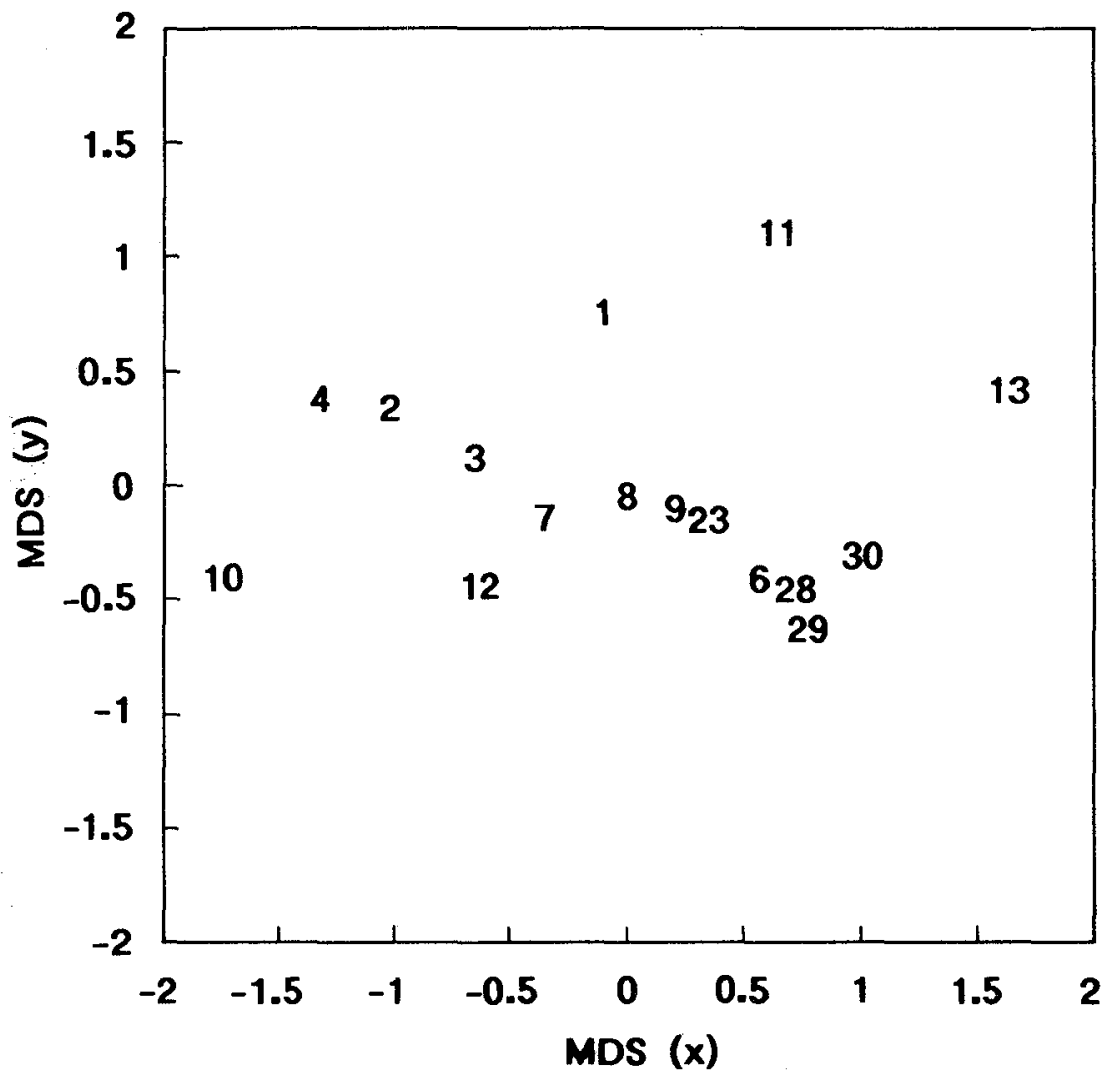

Figure 23 Ordination, as Figure 22, but excluding area 5 from the analysis.

Thiel (1983) reviewed the Atlantic data and showed that densities in general are higher in the east than in the west Atlantic, a pattern which he associated with the higher primary productivity in the east (Figure 3). In the west Atlantic, densities are always lower than $1000 \mathrm{ind} / 10 \mathrm{~cm}^{2}$ along the upper slope, and decrease to less than $100 \mathrm{ind} / 10 \mathrm{~cm}^{2}$ on the abyssal plain (Thiel, 1983). Tietjen et al. (1989) recorded densities of $114 \pm 26 / 10 \mathrm{~cm}^{2}$ on the Hatteras Abyssal Plain, similar to other low values reported for the west Atlantic.

The cold waters off northern Europe (north Atlantic and the Norwegian Sea) are characterized by higher densities than the northeast Atlantic, and also by a larger variability within the different depth zones used here. On the upper slope $(<1000 \mathrm{~m})$ densities vary from 200 to 3500 ind $/ 10 \mathrm{~cm}^{2}$; below $3000 \mathrm{~m}$, densities still reach values from 10 to 800 ind $10 \mathrm{~cm}^{2}$. The comparatively high numbers are related to the higher 
planktonic mortality and the low temperatures which reduce organic degradation rates stimulate and hence the long term availability of food (Thiel, 1983). Pfannkuche and Thiel (1987) reported even higher abundances on the upper slope (from 1100 to $4300 \mathrm{ind} / 10 \mathrm{~cm}^{2}$ ) along a high Arctic depth transect. On the lower slope $(>3000 \mathrm{~m})$ densities of 230-350 ind $/ 10 \mathrm{~cm}^{2}$ were recorded. The authors invoke hydrodynamical processes which cause the downslope transport of under-ice primary production and sustain the food supply.

The low primary productivity in the Mediterranean results in lower densities compared to the northeast Atlantic. Even on the upper slope densities never exceed $1000 \mathrm{ind} / 10 \mathrm{~cm}^{2}$ (Thiel, 1983). The results of a study by Soetaert et al. (1991a, b) along an upper slope depth transect near Corsica, illustrate this tendency. Only canyons, which have a higher food supply due to specific hydrodynamical processes, are characterized by relatively high meiobenthic abundances (Soetaert et al., 1991a, b).

In the Pacific Ocean meiobenthic densities also are generally low. Alongi and Pichon (1988) found that densities never exceed 200 ind/ $10 \mathrm{~cm}^{2}$, and are only exceptionally higher than $100 \mathrm{ind} / 10 \mathrm{~cm}^{2}$ along the upper slope $(<1000 \mathrm{~m})$ in the western Coral Sea (SW Pacific). At abyssal depths in the east central Pacific (Renaud-Mornant and Gourbault, 1990) and the south east Pacific (Schriever et al., 1991) densities are always lower than 200 ind $/ 10 \mathrm{~cm}^{2}$. These areas are all considered to be oligotrophic zones. Only Shirayama (1984a) found higher densities at bathyal (up to $1300 \mathrm{ind} / 10 \mathrm{~cm}^{2}$ ), abyssal (up to $500 \mathrm{ind} / 10 \mathrm{~cm}^{2}$ ) and even hadal depths (up to 430 ind $/ 10 \mathrm{~cm}^{2}$ ) in the western Pacific.

Changes in faunal composition at an ocean-wide scale are to be expected between areas of different productivity, such as from shelf to abyss, upwelling to non-upwelling, and low to higher latitudes. Table 3 compares the results of meiobenthos investigations on a global scale. Only deep stations (below $2000 \mathrm{~m}$ ) have been included to reduce variations caused by depth-related factors, but differences in the relative abundances of certain taxa between different regions are still noticeable. These variations may be attributed to different sediment granulometry, different hydrographic conditions and/or the general availability of food in regions with different surface primary production.

\subsection{Patterns at Different Taxonomic Levels}

Meiobenthic taxonomy is always difficult and time consuming; in the deep sea this problem is compounded by high species diversity and low species dominance. Most deep-sea meiobenthic investigations have, therefore, 
Table 3 Composition of deep-sea meiofauna.

\begin{tabular}{|c|c|c|c|c|c|c|c|}
\hline Author & Area & Provinces & Latitude & $\begin{array}{l}\text { Depth } \\
(\mathrm{m})\end{array}$ & $\underset{(\%)}{\text { Nematoda }}$ & $\begin{array}{l}\text { Copepoda } \\
(\%)\end{array}$ & $\begin{array}{l}\text { Others } \\
(\%)\end{array}$ \\
\hline $\begin{array}{l}\text { Pfannkuche and Thiel, } \\
1987\end{array}$ & $\begin{array}{l}\text { Arctic Ocean } \\
\text { Nansen Basin }\end{array}$ & $\begin{array}{l}\text { Arctic/subarctic } \\
\text { regimes }\end{array}$ & $82^{\circ}$ & $2500-3920$ & 90.2 & 6.6 & 3.2 \\
\hline Dinet, 1979 & $\begin{array}{l}\text { Norwegian Sea } \\
\text { Norwegian Basin }\end{array}$ & & $64-74^{\circ} \mathrm{N}$ & $2465-3709$ & 96.0 & 3.3 & 0.9 \\
\hline This chapter ${ }^{a}$ & West European Basin & $\begin{array}{l}\text { Coastal boundary } \\
\text { regimes }\end{array}$ & $45-52^{\circ} \mathrm{N}$ & $2000-5340$ & 89.8 & 7.1 & 2.1 \\
\hline $\begin{array}{l}\text { Tietjen, 1971; Coull et al. } \\
1977\end{array}$ & $\begin{array}{l}\text { Northwestern Atlantic, NW } \\
\text { Atlantic Basin }\end{array}$ & & $34^{\circ} \mathrm{N}$ & $2000-4000$ & 81.8 & 5.5 & 9.8 \\
\hline This chapter ${ }^{b}$ & Madeiran Abyssai Plain & $\begin{array}{l}\text { Subtropic gyral } \\
\text { province }\end{array}$ & $33^{\circ} \mathrm{N}$ & $4856-5120$ & 92.8 & 6.3 & 1.0 \\
\hline This chapter ${ }^{c}$ & Cape Verde Ridge & $\begin{array}{l}\text { Provinces with } \\
\text { pronounced } \\
\text { seasonality }\end{array}$ & $19-22^{\circ} \mathrm{N}$ & $2041-4652$ & 93.8 & 4.4 & 2.1 \\
\hline Romano and Dinet, 1981 & $\begin{array}{l}\text { NW Indian Ocean, Arabian } \\
\text { Sea }\end{array}$ & & $14-23^{\circ} \mathrm{N}$ & $2390-4727$ & 88.0 & 3.3 & 10.1 \\
\hline Soltwedel (unpubl.) & $\begin{array}{l}\text { Central Atlantic, Middle } \\
\text { oceanic ridge }\end{array}$ & & $1-6^{\circ} \mathrm{S}$ & $2473-5213$ & 84.8 & 10.4 & 3.5 \\
\hline Dinet, 1973 & SE Atlantic, Walvis ridge & & $19-22^{\circ} \mathrm{S}$ & $2800-5170$ & 94.9 & 4.1 & 1.4 \\
\hline Shirayama, 1984a & $\begin{array}{l}\text { Western Pacific, NW Pacific } \\
\text { Basin }\end{array}$ & $\begin{array}{l}\text { Subtropical gyral } \\
\text { province }\end{array}$ & $24-33^{\circ} \mathrm{N}$ & $2430-8260$ & 86.2 & 4.3 & 9.2 \\
\hline Shirayama, 1984a & $\begin{array}{l}\text { Western Pacific, Eastern } \\
\text { Carolina Basin }\end{array}$ & & $0-11^{\circ} \mathrm{N}$ & $2090-5730$ & 86.2 & 5.2 & 8.4 \\
\hline Woods and Tietjen, 1985 & Venezuela Basin & Subtropical basin & $12-15^{\circ} \mathrm{N}$ & $3517-5054$ & 85.2 & 9.0 & 5.8 \\
\hline Alongi, 1992 & $\begin{array}{l}\text { Western Pacific, Coral and } \\
\text { Solomon Sea }\end{array}$ & n.d. & $12-14^{\circ} \mathrm{S}$ & $2395-4350$ & 43.7 & 33.3 & 19.5 \\
\hline
\end{tabular}

n.d., not defined.

Dinet and Vivier, 1977; Pfannkuche, 1985; Rutgers van der Loeff and Lavaleye, 1986; Thiel, 1972; Gooday (unpubl.) + Vanreusel and Vincx (unpubi.).

${ }^{\circ}$ Gooday and Soltwedel (unpubl.).

${ }^{C}$ Dinet (unpubl.). 
dealt with only taxonomic levels higher than species (Thiel, 1983, and references therein). Species level ecological data are only available for the nematodes, copepods and foraminiferans from a limited number of areas.

\subsubsection{Nematodes}

In the deep northeast Atlantic, only two studies (areas 6-10), from the Bay of Biscay, have dealt with the taxonomic composition of nematode communities. One study is of two stations in the shelf break area along the Spanish coast (Vanreusel et al., 1992), and the other of several abyssal stations (Dinet and Vivier, 1979). Rutgers van der Loeff and Lavaleye (1986) examined the taxonomic composition of the nematode communities at the abyssal DORA area, to study the composition of different feeding types.

Thirty-five families are recorded from the Gulf of Biscay, of which 11 are common to both the shelf break and the abyssal locations. Dominant $(>10 \%)$ families from the abyssal plain in the Gulf of Biscay are the Monhysteridae and Chromadoridae, followed by the Oxystominidae, Desmoscolecidae, Microlaimidae and Axonolaimidea $(>5 \%)$. At the shelf break stations along the Spanish coast, the Xyalidae and, again, Chromadoridae are the dominant families $(>10 \%)$, while the Oxystominidae, Desmoscolecidae and Microlaimidae are subdominant $(>5 \%)$. Other important families at these stations included the Comesomatidae, Cyatholaimidae and Selachinematidae. At the genus level the similarity between abyssal and shelf break samples in the Gulf of Biscay is less striking. Only Halalaimus, Microlaimus, Acantholaimus, Leptolaimus, Diplopeltula and Sabatieria are common dominant to subdominant genera (with a relative abundance $>1 \%$ ) for both depth zones. The dominant genus at the abyssal sites, Theristus (represented by 42 different species), is replaced by two closely related genera, Daptonema and Trichotheristus at the shelf break sites.

Dinet and Vivier (1979) investigated species composition at the abyssal sites, noting that the majority were new to science; a Syringolaimus species was dominant, followed by three Microlaimus spp., three species of Spilipherinae, and eight Theristus spp.

In the Bay of Biscay, diversity is usually high, both in terms of species numbers and evenness. At the abyssal sites (six stations) 317 species in 109 genera were recorded, with between 50 and 20 species per station, the rank 1 species dominance did not exceed $11 \%$. At the shelf break a total of 79 genera was found at the two stations with, respectively, 62 and 46 genera per station. Here again the high diversity is due to the numbers of genera present (and thus even more for species) and the low rank 1 generic dominance (maximum 10-18\%). 
Rutgers van der Loeff and Lavaleye (1986) recorded a lower density at the DORA site and suggest that, referring to Dinet and Vivier (1979), ". . . this may be explained by their more accurate way of identifying the different nematode species ...". Nevertheless the study area still shows the high nematode diversity thought to be characteristic at the deep-sea benthos.

One of the oldest, but still frequently used, classifications of nematodes into functional groups is that of Wieser (1953) who defined four feeding types (i.e. selective and non-selective deposit feeders, epistrate feeders and predators/omnivores) based on the buccal morphology. At the DORA site (Rutgers van der Loeff and Lavaleye, 1986) non-selective deposit feeders are dominant $(50 \%)$. Selective deposit feeders are represented by $25.6 \%$, epistratum feeders and predators/omnivores by, respectively, 14.7 and $9.7 \%$. In the Bay of Biscay, all dominant genera except Microlaimus are defined by Wieser (1953) as deposit feeders.

Depth-related factors are assumed to be the main controlling influence for the nematode communities in the Bay of Biscay. Dinet and Vivier (1979) found that 135 species were present only at shallower stations than $3000 \mathrm{~m}$, while 61 species were restricted to the zone deeper than $4000 \mathrm{~m}$. Diversity decreased from 2000 to $4700 \mathrm{~m}$ depth. According to Tietjen $(1976,1984)$ species diversity is directly related to sediment heterogeneity, predictability of the environment and/or the proximity to areas of high surface productivity. More recently, he confirmed the presumed relation with sediment heterogeneity (Tietjen, 1989), and also suggested that greater fluxes of sedimenting material and bioturbation rates can enhance species diversity in some areas of the deep sea (Tietjen, 1992).

Elsewhere, published studies of deep-sea nematodes carried out at lower taxonomic levels (family/genus/species) are mainly concentrated in the west Atlantic: off N Carolina (Tietjen, 1971, 1976), in the Venezuela Basin (Tietjen, 1984), near the Scotian Rise (Thistle and Sherman, 1985) and from the Puerto Rico Trench and the Hatteras Abyssal Plain (Tietjen, 1989). Jensen (1988) investigated some structural aspects of the nematode communities from the Norwegian Sea.

High relative abundances of the Xyalidae or Monhysteridae, Oxystominidae and Desmoscolecidae are general in the west Atlantic (Tietjen, 1976, 1984, 1989; Thistle and Sherman, 1985), and similar to the abyssal region of the Bay of Biscay. The Chromadoridae are dominant at the abyssal sites in the northeast Atlantic and in some areas of the west Atlantic (Thistle and Sherman, 1985; Tietjen, 1989) but not at the deeper sites $(>800 \mathrm{~m}$ ) off $\mathrm{N}$ Carolina. The dominance of the Linhomoeidae off $\mathrm{N}$ Carolina is in marked contrast to the results from the Bay of Biscay. The high numbers of the Cyatholaimidae and Comesomatidae off $\mathrm{N}$ Carolina, especially along the lower slope, are similar to that reported in the shelf break region of the Bay of Biscay. At the genus level the affinity 
between the west and east Atlantic is more pronounced. Theristus, Halalaimus, Microlaimus, Desmoscolex and Acantholaimus are the dominant genera in the east as well as in the west. This is illustrated by Table 4 which also indicates that the deepest sites $(>1500 \mathrm{~m})$ off $\mathrm{N}$ Carolina are exceptional: only Microlaimus, Theristus and Desmoscolex are well represented here. The genera Porocoma and Aegialoalaimus, which are dominant off N Carolina, were not recorded by Dinet and Vivier (1979). The high abundance of Desmodora, Sabatieria, and Pselionema on the lower slope off $\mathrm{N}$ Carolina is more in accord with the situation at the shelf break in the east, as reported by Vanreusel et al. (1992). However, Daptonema, dominant in the east, seems to be replaced by Monhystera in the west.

The dominance of deposit feeders at the DORA site in the northeast Atlantic (Rutgers van der Loeff and Lavaleye, 1986) is of the same order

Table 4 Dominant nematode genera in the northeast Atlantic (Bay of Biscay) and their presence in the west Atlantic

\begin{tabular}{|c|c|c|c|c|c|c|}
\hline Genera & $\begin{array}{c}\text { Dinet and } \\
\text { Vivier, } 1979\end{array}$ & $\begin{array}{c}\text { Vanreusel } \\
\text { et al", } \\
1992<1\end{array}$ & $\begin{array}{c}\text { Tiet } \\
1971, \\
500 \mathrm{~m}\end{array}$ & $\begin{array}{l}\text { jen } \\
1976 \\
<1500\end{array}$ & $\begin{array}{l}\text { Thistle and } \\
\text { Sherman, } \\
\text { m } 1985\end{array}$ & $\begin{array}{c}\text { Tietjen, } \\
1989\end{array}$ \\
\hline Theristus & $* *$ & & $* *$ & $* *$ & $* *$ & $* *$ \\
\hline Spiliphera & $* *$ & & & & & \\
\hline Halalaimus & $* *$ & $* *$ & $* *$ & & $* *$ & $* *$ \\
\hline Microlaimus & $* *$ & $*$ & $* *$ & $* *$ & $* *$ & $* *$ \\
\hline Acantholaimus & $* *$ & $*$ & & & $* *$ & $* *$ \\
\hline Desmoscolex & $* *$ & & $* *$ & $* *$ & $*$ & $* *$ \\
\hline Syringolaimus & $* *$ & & & & $*$ & * \\
\hline Leptolaimus & $*$ & $*$ & & $* *$ & & $* *$ \\
\hline Campylaimus & * & & & & & $*$ \\
\hline Diplopeltula & $*$ & $* *$ & & & & * \\
\hline Thalassoalaimus & * & & & & & $*$ \\
\hline Sphaerolaimus & * & & $* *$ & $* *$ & & $* *$ \\
\hline Longicyatholaimus & $*$ & & & ** & & \\
\hline Tricoma & $*$ & & $* *$ & & & $* *$ \\
\hline Cervonema & $*$ & & & & & $*$ \\
\hline Sabatieria & $*$ & $* *$ & $* *$ & $* *$ & $*$ & $*$ \\
\hline Daptonema & & $* *$ & & & & \\
\hline Richtersia & & $* *$ & & & & \\
\hline Prochromadorella & & $* *$ & & & & \\
\hline Actinonema & & $* *$ & & & & $* *$ \\
\hline Pselionema & & $* *$ & * & & & \\
\hline & \multicolumn{2}{|c|}{ East Atlantic } & \multicolumn{4}{|c|}{ West Atlantic } \\
\hline
\end{tabular}

$* *>3 \%, *>1 \%$. 
of magnitude as in the west Atlantic (50-80\%) (Tietjen, 1976, 1984; Thistle and Sherman, 1985) and in the Norwegian Sea (Jensen, 1988). However, Tietjen (1971) found changes in the distribution of the feeding types (especially the epistrate feeders) which were highly correlated with changes in sediment composition. Tietjen (1984) suggested that poorly sorted sediments, which are characterized by a greater diversity of microhabitats and thus also a greater variety of food sources, may enhance the abundance of epistrate feeders in some deep-sea areas.

Estimates of nematode species diversity and evenness in the northeast Atlantic are within the range of those for the west Atlantic (Tietjen, 1984, 1989) and the Norwegian Sea (Jensen, 1988). The high diversity is generally maintained by a high number of species and an even distribution of specimens among the species. Only Tietjen (1976) described somewhat lower values for the deep sea off $\mathbf{N}$ Carolina.

\subsubsection{Copepods}

Also in the case of copepods, no complete diversity analysis has been made of northeast Atlantic deep-sea communities. Nevertheless, some taxonomic studies suggest that these assemblages are highly diverse and comprise many undescribed species. Bodin (1968) recorded 29 species, including 25 new to science, from a collection of 47 individuals collected in the deep Bay of Biscay. In the same area, 11 new species were found by Dinet $(1977,1981)$ in a study of a single genus Pontostratiotes, which predominates the large-size fraction of meiobenthos. Although most harpacticoid families are represented in the area, the assemblages are dominated by Cletodidae, Diosaccidae, Ectinosomatidae, Tisbidae and particularly the Cerviniidae which can be considered as a typical deep-sea taxon.

A bathymetric zonation, mainly characterized by a change in species composition occurring between 2000 and $3000 \mathrm{~m}$ depth, was identified by Dinet (1985) using the genus Pontostratiotes.

\subsubsection{Foraminifera}

Deep-sea foraminiferal populations are also highly diverse. Gooday (1986a) and Gooday and Lambshead (1989) found 78-105 species in the top $1 \mathrm{~cm}$ of sediment samples $\left(3.46 \mathrm{~cm}^{2}\right)$ from the bathyal Porcupine Seabight (area $2,1340 \mathrm{~m}$ ). Rather lower numbers of species were present in similar samples from area 1 (395 m; 55-64 species) and area 3 (4494 m; 53-76 species) in the Seabight (Cartwright, 1988) and from the abyssal BIOTRANS site (area 12; 62 species) (Gooday, unpublished). Diversity is 
also high in abyssal plain samples; the top $1 \mathrm{~cm}$ of complete multiple cores $\left(25 \mathrm{~cm}^{2}\right)$ from the Porcupine Abyssal Plain (area 4) and the Madeira Abyssal Plain (area 23) yielded 110-143 species and 114 species respectively.

Calcareous taxa of the kind normally studied by geologists make up $20-45 \%$ of meiobenthic foraminiferal assemblages in bathyal samples but a much lower proportion (often $<10 \%$ ) at abyssal sites (Gooday, 1986a, 1990; Gooday and Lambshead, 1989; Gooday, unpublished). Much more abundant in abyssal assemblages are small, delicate, soft-bodied taxa such as saccamminids and allogromiids (Gooday, 1986a, b, 1990). Hormosinacean genera such as Reophax and Leptohalysis may also be common.

Corliss and Chen (1988) observed that different morphotypes of deep-sea benthic foraminifera have distinct distribution patterns with water depth. Moreover, the relative abundances of epi- and infaunal species appeared to be related to the organic carbon content of surface sediments. The authors concluded that bathymetric groupings based on morphology and microhabitat preferences are related to the flux of organic carbon to the seafloor.

\subsection{Small-scale Spatial Patterns}

It is generally accepted that metazoan meiobenthos densities are much more variable on a small scale in the deep sea than in shallow waters. For instance, Pfannkuche (1993b) found no seasonal variations in abundance or biomass since the variability between samples from a single cruise in the BIOTRANS area was greater than the seasonal changes. However, there is little information on the scale of this spatial variation and only a few studies consider possible causes. Biogenic structures such as burrows, depressions and mounds produced by the larger macrobenthos clearly influence the distribution of the meiobenthos on small scales, for example within box corers (Thistle and Eckman, 1988). Particulate organic matter is trapped occasionally by such structures. Opportunistic taxa, such as nematodes (Aller and Aller, 1986), may become unusually abundant early in the colonization of these patches, increasing variability in faunal composition within a sampling station (Grassle and Mosse-Pocteous, 1987). Thistle and Sherman (1985) found evidence for the association of nematode species with pebbles which they assumed to provide a refuge for meiobenthos from some type of predators. At the species level, there is no evidence of an association between small-scale variations in nematode abundance and variance in the abundance of bacteria or several classes of biogenic structures. However, individual nematode species may respond to organic matter inputs. Thiel et al. (1989-1990) 
observed the association of one species of the genus Monhystera with aggregated phytodetritus deposits at the BIOTRANS site. Numerous exuvia of ectinosomatid harpacticoids were also observed in phytodetritus from this site. One of several possibilities is that these exuviae are derived from an annual reproductive event related to the seasonal phytodetrital input. The small-scale patchiness of the food supply is often presumed to be the main source of variation in densities (Grassle and Mosse-Porteous, 1987). It was hypothesized by Thistle (1983) that, as the rates of physical and biological disturbance decrease with depth, the habitat heterogeneity created by organisms becomes increasingly available to other organisms for habitat partitioning or as prey refuges, allowing larger numbers of species to be accommodated locally. However, for copepods, no increase in diversity was measured in sites with a greater degree of association (Thistle, 1983).

\section{VERTICAL SPATIAL PATTERNS}

\subsection{Suprabenthic Microhabitats}

Deep-sea foraminifera commonly live attached to surfaces elevated above the sediment water interface. In the northeast Atlantic, calcareous species (e.g. Cibicides weullerstorfi, Planulina ariminesis) with plano-convex tests have been found on substrata such as stones, sponge skeletons, hydroid stalks, ascidians, polychaete tubes and the tests of other foraminifera (Weston, 1985; Lutze and Thiel, 1989). Agglutinating species, mainly trochamminaceans (e.g. Tritaxis conica), also commonly occur on hard substrata in samples from the Porcupine Seabight and off NW Africa (Gooday, unpublished observations).

Phytodetritus represents another elevated habitat. Gelatinous aggregates of this material harbour large foraminiferal populations dominated by species such as Epistominella exigua and Tinogullmia riemanni (Gooday, 1988, 1990; Gooday and Lambshead, 1989). Nematodes, many belonging to the genus Monhystera, also occur within phytodetritus (Thiel et al., 1989-1990). In one case, 27 nematodes occurred in a single aggregate $(0.3 \mathrm{ml}$ volume) from the BIOTRANS site.

\subsection{Vertical Distribution Within the Sediment}

Few studies on the meiofauna of the northeast Atlantic have quantified the vertical profiles of meiofauna abundances within the sediment. The 
data used were supplied by Dinet and Vivier, 1977; Gooday, unpublished; Lambshead and Ferrero, unpublished; Pfannkuche, 1985; Rutgers van de Loeff and Lavaleye, 1986; Soltwedel, unpublished; Thiel, 1972a; Vanreusel et al., 1992 and Vanreusel and Vincx, unpublished. In order to make meaningful comparisons between data-sets, we have restricted our analysis to data describing the top $5 \mathrm{~cm}$ of sediment divided into $1-\mathrm{cm}$ sections.

Data for total metazoan meiofauna, nematodes, foraminiferans and harpacticoid copepods and nauplii are considered. Figures 24-26 show the data used for the following results. The number of observations available for each site varied greatly from $n=1$ to $n=12$. Therefore, mean values were calculated for all sites where $n>1$ and these "summary means" were used for the production of individual vertical profile figures and the subsequent statistical analyses.

The following analysis is based on values for percentage total abundance at each sediment depth level calculated for each site. Vertical profiles where the organisms are concentrated in the surface sediment levels will be referred to as "superficial" and those where the organisms extend to the lower sediment levels in greater numbers will be referred to as "deep".

To gain a generalized picture of differences between the four faunistic groups, average vertical profiles for the entire study area were calculated using the summary means (Table 5, Figure 24). Percentage total

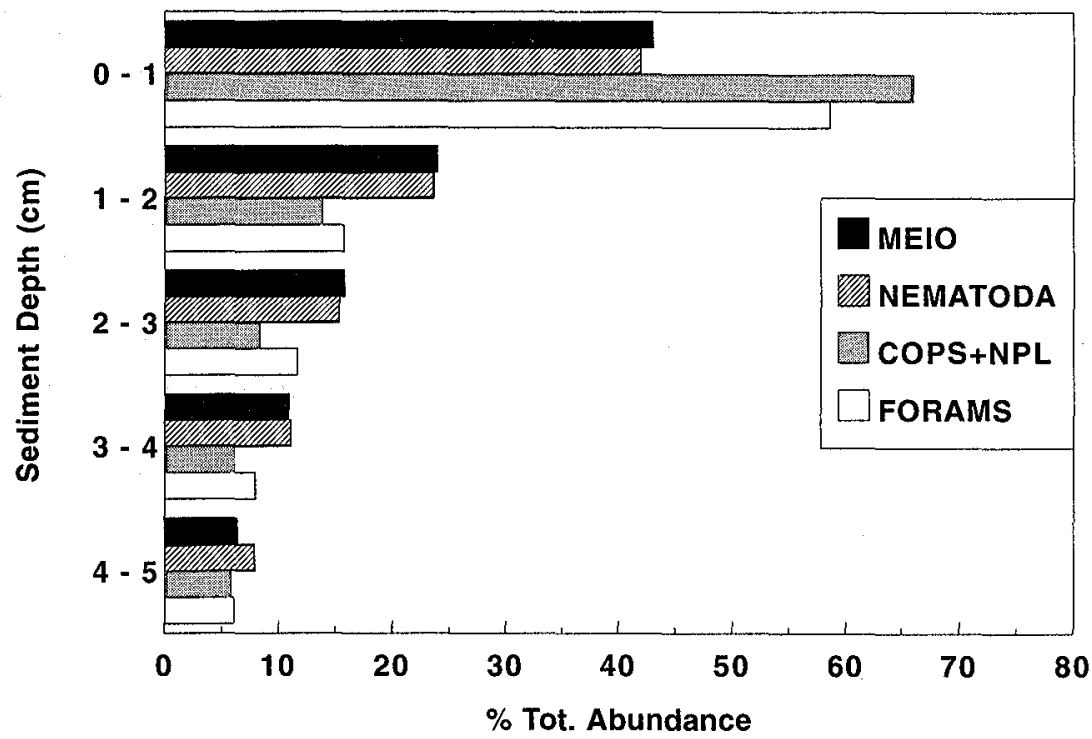

Figure 24 Percentage total abundance of four taxa at each sediment depth: average vertical profile for the entire study area (northeast Atlantic). 


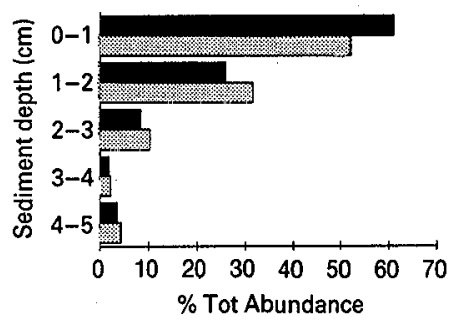

Porcupine Seabight 960m [1]

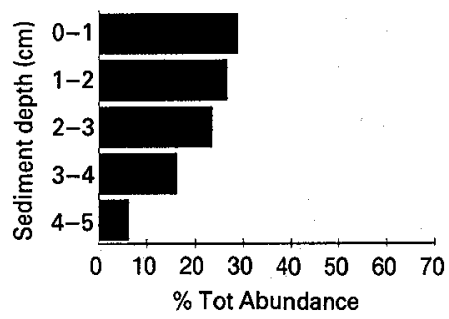

Porcupine Seabight (July) 1340m [2]

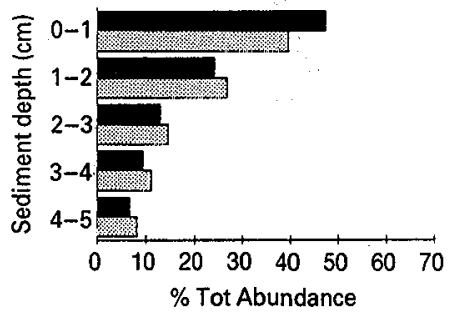

Porcupine Seabight 2785m [2]

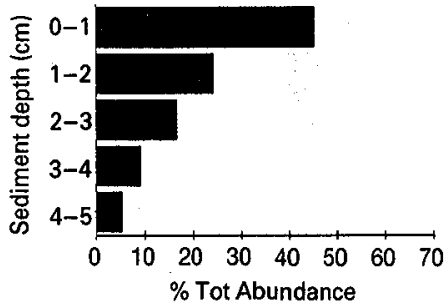

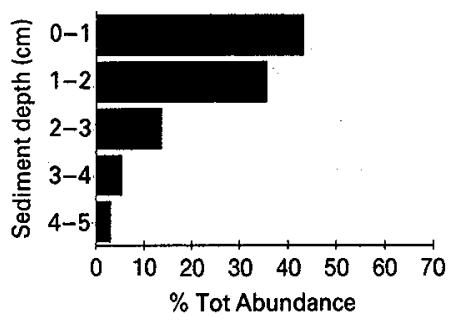

Porcupine Seabight (April) 1340m [2]

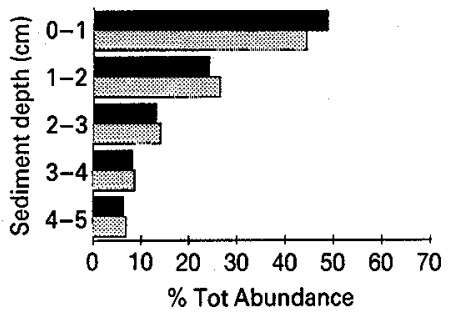

Porcupine Seabight 2000m [2]

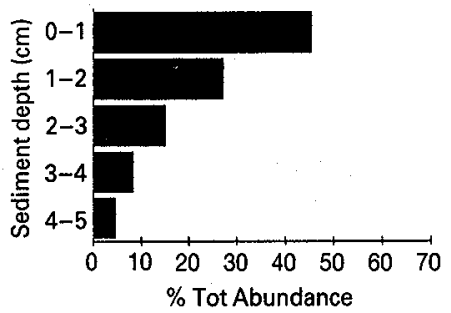

Porcupine Seabight 4090m [3]

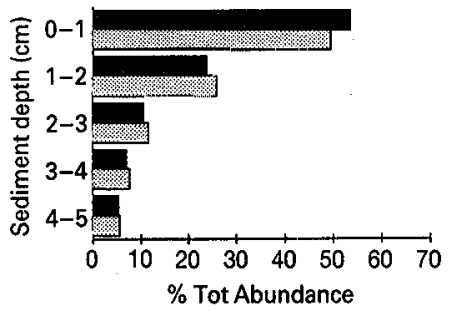

Figure 25 Individual vertical profiles percentage total abundance of all meiofauna (black) and nematodes (grey) for study areas 1 and 2 and part of 3 (cf. Table 1); number of observations in brackets. 


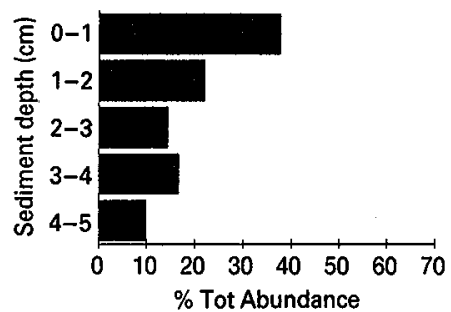

Porcupine Abyssal Plain 4850m [4]

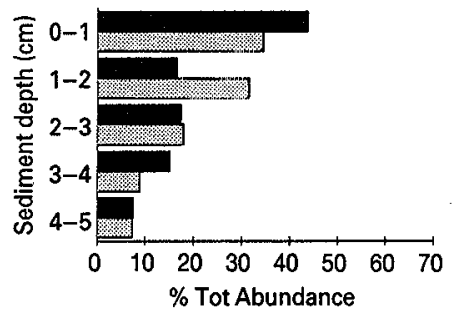

Gulf of Biscay N 148m [5]

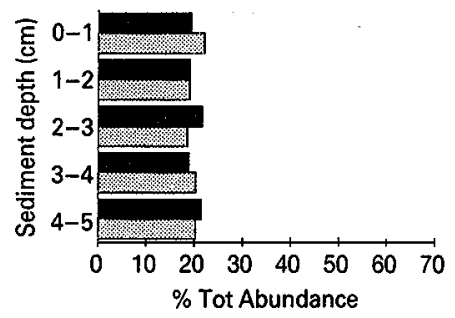

Gulf of Biscay N 2127m [7]

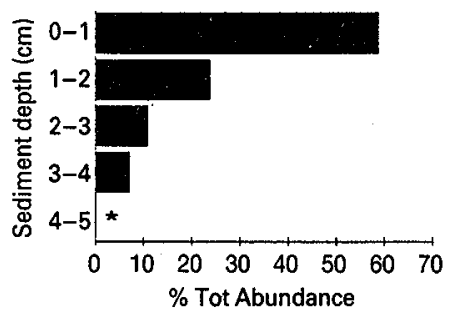

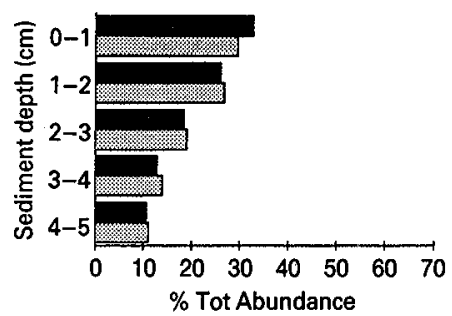

Gulf of Biscay N 70m [5]

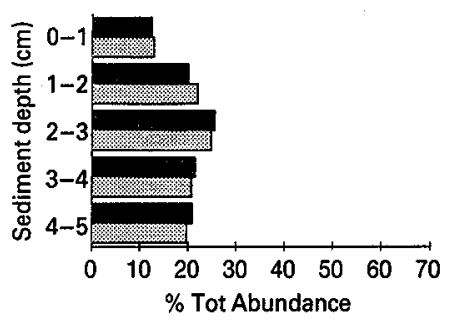

Gulf of Biscay N 170m [5]

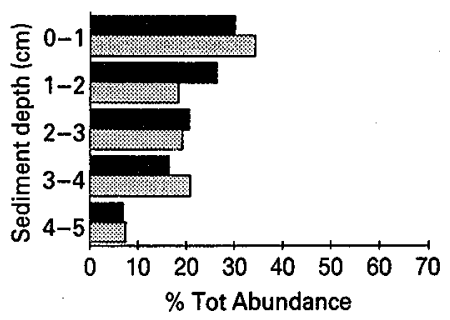

Gulf of Biscay N 2835m [7]

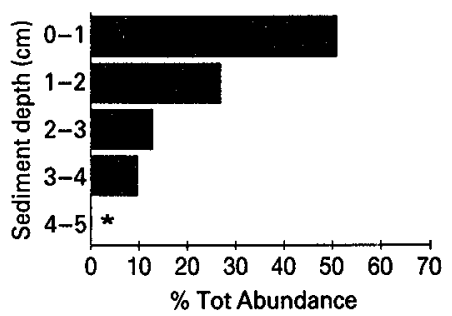

Figure 26 Individual vertical profiles percentage total abundance of all meiofauna (black) and nematodes (grey) for study areas 3 (part), 4, 5, 7 (cf. Table 1); number of observations in brackets. 
Table 5 Average values and statistics for percentage total abundance of metazoan meiofauna, nematodes, copepods and nauplii and foraminifera at five sediment depth levels. Averages calculated from sample means.

\begin{tabular}{|c|c|c|c|c|c|c|c|c|}
\hline Sample means & $N$ & Average & Variance & SD & SE & Minimum & Maximum & Range \\
\hline \multicolumn{9}{|l|}{$0-1 \mathrm{~cm}$} \\
\hline Meiofauna & 27 & 43.0444 & 146.188 & 12.0908 & 2.32688 & 12.4500 & 61.9000 & 49.4500 \\
\hline Nematodes & 20 & 41.9975 & 178.013 & 13.3421 & 2.98339 & 12.8200 & 63.2500 & 50.4300 \\
\hline Copepods and nauplii & 11 & 65.9373 & 476.302 & 21.8244 & 6.58029 & 33.6787 & 98.3871 & 64.7084 \\
\hline Foraminifera & 10 & 58.5846 & 314.117 & 17.7234 & 5.60462 & 22.1959 & 80.7829 & 58.5870 \\
\hline \multicolumn{9}{|l|}{$1-2 \mathrm{~cm}$} \\
\hline Meiofauna & 27 & 23.9130 & 16.8529 & 4.10523 & 0.79005 & 16.5400 & 35.3400 & 18.8000 \\
\hline Nematodes & 20 & 23.6000 & 24.8725 & 4.98724 & 1.11518 & 13.4600 & 31.8500 & 18.3900 \\
\hline Copepods and nauplii & 11 & 13.8572 & 59.5248 & 7.71523 & 2.32623 & 1.61290 & 25.0000 & 23.3871 \\
\hline Foraminifera & 10 & 15.7483 & 31.9869 & 5.65570 & 1.78849 & 9.48991 & 23.8536 & 14.3637 \\
\hline \multicolumn{9}{|l|}{$2-3 \mathrm{~cm}$} \\
\hline Meiofauna & 27 & 15.7548 & 22.6977 & 4.76421 & 0.91687 & 5.40000 & 25.4800 & 20.0800 \\
\hline Nematodes & 20 & 15.3310 & 24.2667 & 4.92612 & 1.10151 & 4.63000 & 24.7400 & 20.1100 \\
\hline Copepods and nauplii & 11 & 8.33085 & 41.3939 & 6.43377 & 1.93986 & 0.00000 & 17.0483 & 17.0483 \\
\hline Foraminifera & 10 & 11.6756 & 40.8625 & 6.39235 & 2.02144 & 3.79597 & 25.7266 & 21.9306 \\
\hline \multicolumn{9}{|l|}{$3-4 \mathrm{~cm}$} \\
\hline Meiofauna & 27 & 10.9044 & 25.9985 & 5.09887 & 0.98128 & 1.59000 & 21.3600 & 19.7700 \\
\hline Nematodes & 20 & 11.1475 & 32.7532 & 5.72304 & 1.27971 & 1.64000 & 20.8200 & 19.1800 \\
\hline Copepods and a nauplii & 11 & 6.10382 & 54.4696 & 7.38036 & 2.22526 & 0.00000 & 20.2073 & 20.2073 \\
\hline Foraminifera & 10 & 7.96185 & 19.1303 & 4.37381 & 1.38312 & 2.90698 & 15.5651 & 12.6581 \\
\hline \multicolumn{9}{|l|}{$4-5 \mathrm{~cm}$} \\
\hline Meiofauna & 27 & 6.38370 & 27.5955 & 5.25314 & 1.01097 & 0.00000 & 21.3700 & 21.3700 \\
\hline Nematodes & 20 & 7.92250 & 22.2688 & 4.71898 & 1.05520 & 1.45000 & 20.1900 & 18.7400 \\
\hline Copepods and nauplii & 11 & 5.77072 & 64.1662 & 8.01038 & 2.41522 & 0.00000 & 25.0000 & 25.0000 \\
\hline Foraminifera & 10 & 6.02957 & 10.6683 & 3.26624 & 1.03288 & 2.60973 & 12.6588 & 10.0491 \\
\hline
\end{tabular}


Table 6 Mann-Whitney comparisons of percentage total abundance of metazoan meiofauna $(\mathbf{M})$, nematodes $(\mathrm{N})$, copepods and nauplii (C) and foraminifera (F) at five sediment depth levels. N/S = not significant; ${ }^{*}=p<0.05 ;{ }^{* *}=p<0.01 ;{ }^{* * *}=p<0.001$.

\begin{tabular}{|c|c|c|c|c|}
\hline & & $\mathbf{M}$ & $\mathbf{N}$ & $\mathrm{C}$ \\
\hline \multicolumn{5}{|l|}{$0-1 \mathrm{~cm}$} \\
\hline & $\mathbf{N}$ & $\mathrm{N} / \mathrm{S}$ & & \\
\hline & C & $\begin{array}{l}* * \\
* *\end{array}$ & $\begin{array}{l}* * \\
* *\end{array}$ & $\mathrm{~N} / \mathrm{S}$ \\
\hline & & & & \\
\hline \multicolumn{5}{|l|}{$1-2 \mathrm{~cm}$} \\
\hline & $\mathrm{N}$ & $\mathrm{N} / \mathrm{S}$ & & \\
\hline & $\mathrm{C}$ & $\begin{array}{l}* * * \\
* * *\end{array}$ & $\begin{array}{l}* * \\
* *\end{array}$ & \\
\hline & $F$ & & we & N/S \\
\hline \multicolumn{5}{|l|}{$2-3 \mathrm{~cm}$} \\
\hline & $\mathrm{N}$ & $\mathrm{N} / \mathrm{S}$ & & \\
\hline & C & $* *$ & $* *$ & \\
\hline & $F$ & * & $\mathrm{N} / \mathrm{S}$ & $\mathrm{N} / \mathrm{S}$ \\
\hline \multicolumn{5}{|l|}{$3-4 \mathrm{~cm}$} \\
\hline & $\mathrm{N}$ & $\underset{*}{\mathrm{~N} / \mathrm{S}}$ & & \\
\hline & $\begin{array}{l}\mathrm{C} \\
\mathrm{F}\end{array}$ & ${ }^{*} / \mathrm{S}$ & $\begin{array}{l}\text { N/S } \\
\text { N/S }\end{array}$ & $N / S$ \\
\hline \multicolumn{5}{|l|}{$4-5 \mathrm{~cm}$} \\
\hline & $\mathbf{N}$ & $\mathrm{N} / \mathrm{S}$ & & \\
\hline & C & $\mathrm{N} / \mathrm{S}$ & $\mathrm{N} / \mathrm{S}$ & \\
\hline & $F$ & $\mathrm{~N} / \mathrm{S}$ & $\mathrm{N} / \mathrm{S}$ & $\mathrm{N} / \mathrm{S}$ \\
\hline
\end{tabular}

abundances of the four faunistic groups at each sediment depth level were compared using a Mann-Whitney U-test (Table 6).

Metazoan meiofauna and nematodes showed no significant differences in percentage total abundance at any sediment depth. Average percentage abundance in the surface centimetre was just over $40 \%$ decreasing gradually with depth. Both copepods and foraminifera were significantly more abundant than metazoan meiofauna and nematodes in the surface centimetre (average percentage abundance $66 \%$ copepods, $57 \%$ foraminifera) of sediment and correspondingly less abundant in many of the lower sediment layers. There were, however, no significant differences in the deepest $(4-5 \mathrm{~cm})$ sediment level or between copepods and foraminifera. This may have been due both to low numbers of individuals and in the case of the test between copepods and foraminifera due to the smaller data-set available for analysis. 


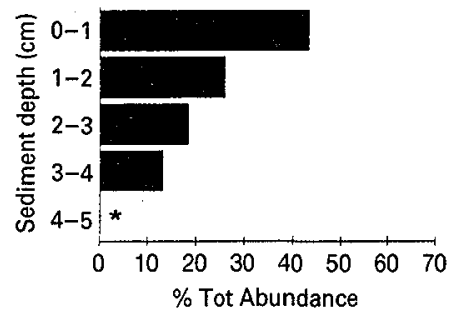

Gulf of Biscay S 123m [6]

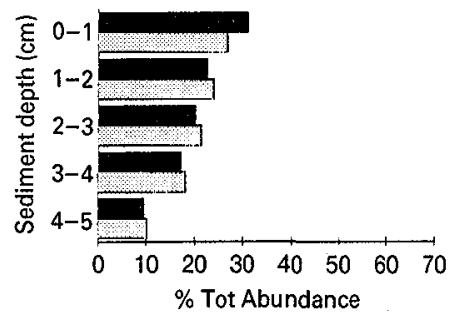

Biotrans 4538m [12]

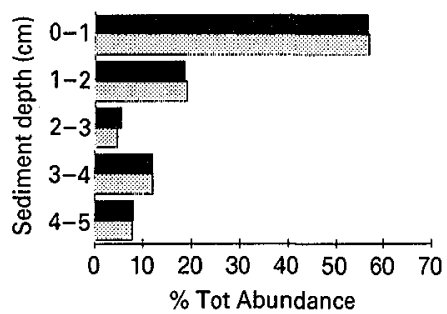

Biotrans 114 4560m [12]

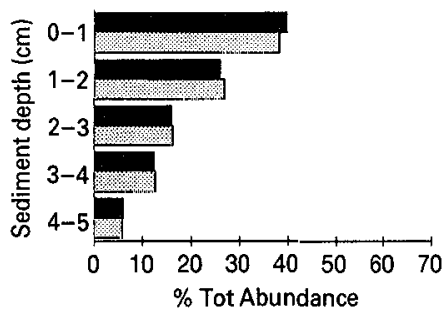

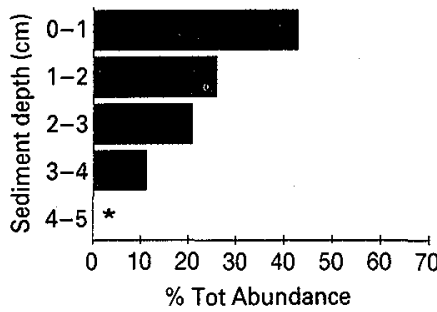

Gulf of Biscay $S 300 \mathrm{~m}[6]$

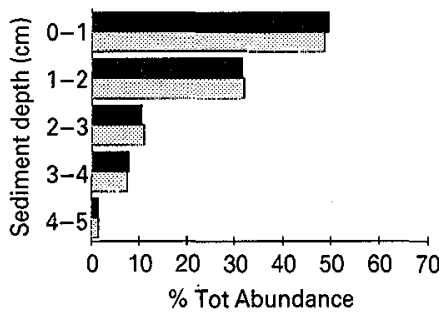

Biotrans $1134560 \mathrm{~m}$ [12]

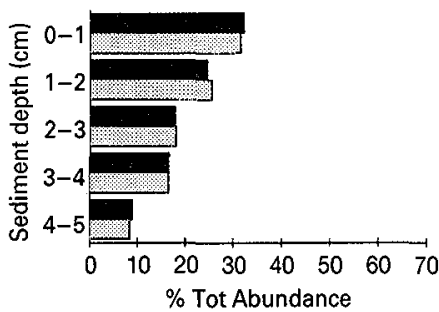

Biotrans 115 4560m [12]

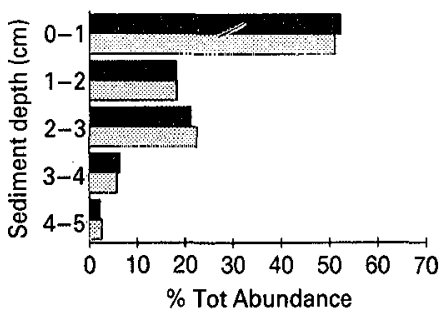

Figure 27 Individual vertical profiles percentage total abundance of all meiofauna (black) and nematodes (grey) for study areas 6, 9, 12 (cf. Table 1); number of observations in brackets. 

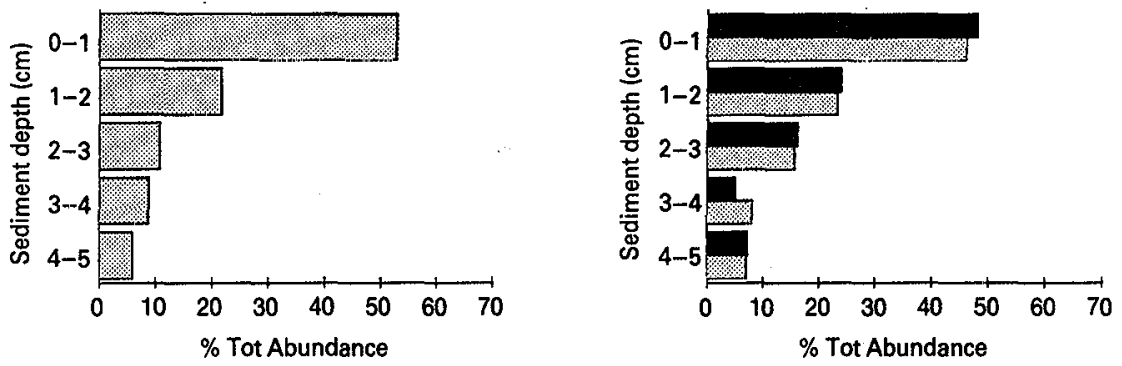

Madeira Abyssal Plain 4856m [23]

Madeira Abyssal Plain 4950m [23]
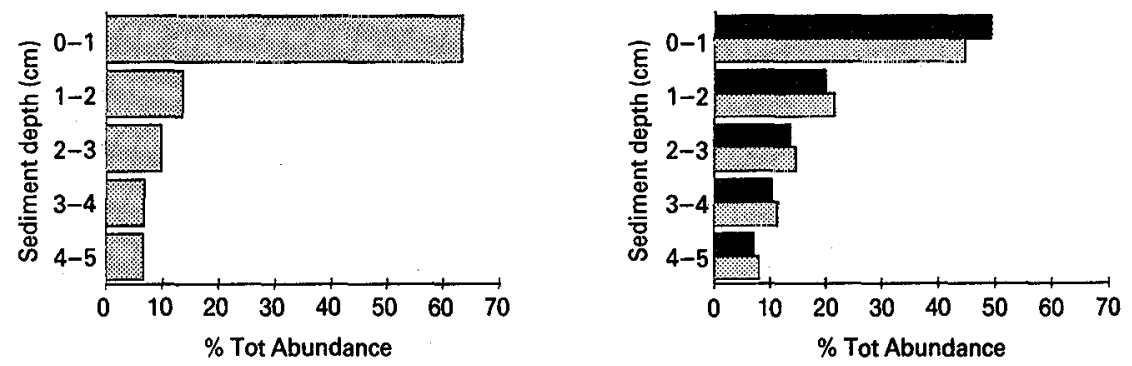

Madeira Abyssal Plain 5120m [23]

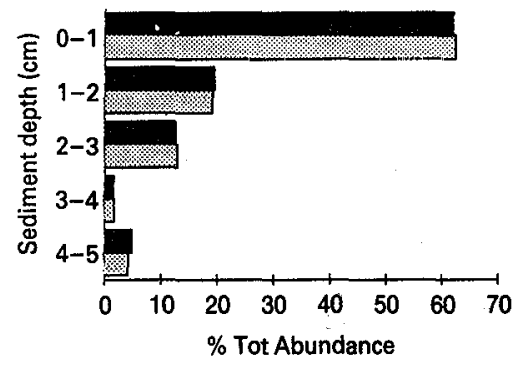

Figure 28 Individual vertical profiles percentage total abundance of all meiofauna (black) and nematodes (grey) for study areas 11, 13, 23 (cf. Table 1); number of observations in brackets. 
Vertical profiles for 25 sites at 11 of the designated study areas (see Table 1) are shown in Figures 25-28. In general, abundances of organisms were greatest in the top centimetre of sediment and decreased gradually with depth. Twelve of the 27 profiles had between 40 and $50 \%$ of the metazoan meiofauna to be found in the top centimetre. A further six profiles each were found to have $30-40 \%$ and $50-60 \%$ of total metazoan meiofauna in the top centimetre of sediment. In all but three of the profiles, less than $10 \%$ of the total abundance was found at the $4-5 \mathrm{~cm}$ sediment depth. Dinet and Vivier (1977) measured abundances to a depth of $4 \mathrm{~cm}$ but still found less than $10 \%$ of total abundance at the lowest sediment depth at two of the four sites studied.

Two geographical areas, the Porcupine Seabight/Abyssal Plain (areas 1-4) and Bay of Biscay (areas 5, 6, 7 and 9), have received most study. In the Porcupine Seabight, profiles showed a tendency to become deeper with increasing depth to $960 \mathrm{~m}$ where only $29 \%$ of the individuals were found in the surface centimetre. However, at $1340 \mathrm{~m}$, the profiles were more superficial with $40-50 \%$ of individuals in the surface centimetre and this profile remained quite consistent at all sites down to a depth of $2785 \mathrm{~m}$. At the deeper sites, profiles were more variable showing both deeper and more superficial distributions. Sites in the Bay of Biscay were taken from two different localities in the north (areas 5,7 and 9) and south (area 6) of the Bay. In the north, the two shallowest stations at 70 and $148 \mathrm{~m}$ showed remarkably deep vertical profiles both having subsurface maxima. At $170 \mathrm{~m}$ the profile remained rather deep but was more typical in shape having a surface maximum of $30 \%$. The trend for increasingly superficial profiles continued at the 2127 and $2835 \mathrm{~m}$ sites where $>50 \%$ of individuals were found in the surface centimetre but at the deepest sites ( 4171 and $4641 \mathrm{~m}$ ), the profiles were slightly deeper.

Profiles from the four BIOTRANS sites (area 12) exhibited considerable variation with both superficial, intermediate and deeper vertical distributions recorded and values for the top centimetre ranging from 32 to $56 \%$.

At the deepest sites sampled, the Iberian Sea (area 13) and Madeira Abyssal Plain (area 23), profiles were rather superficial with $>45 \%$ of individuals in the surface centimetre and particularly on the Madeira Abyssal Plain at $5120 \mathrm{~m}$ where $62 \%$ of the individuals were found in the surface centimetre.

\subsubsection{Nematodes}

Vertical profiles for 20 sites at 10 of the designated study areas (see Table 1) are shown in Figures 25-28. Profiles from nine of the areas and 17 of 

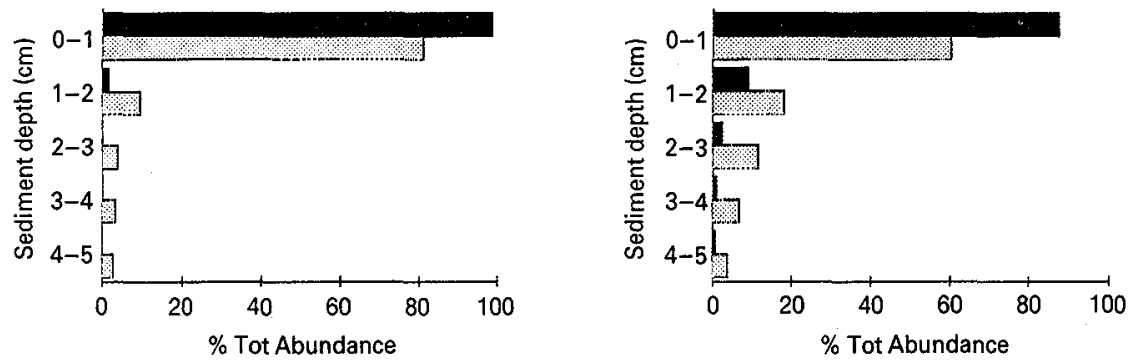

Porcupine Seabight (July) 1340m [2]

Porcupine Seabight 4090m [3]
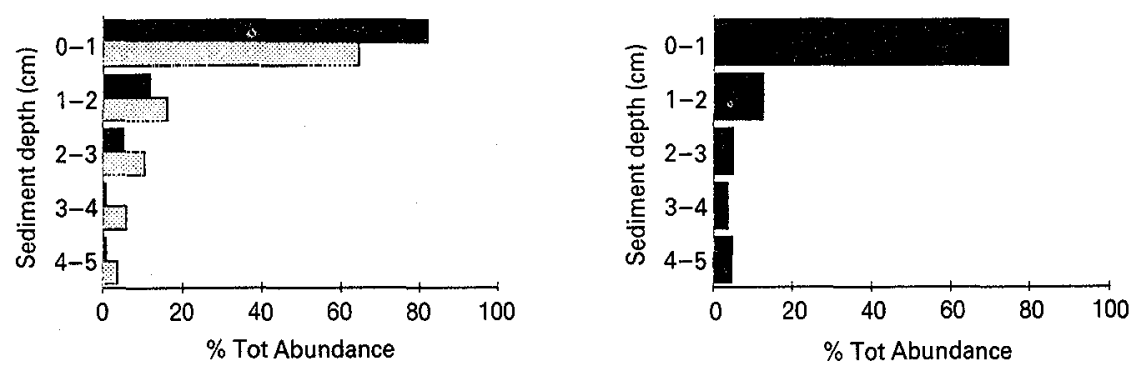

Porcupine Seabight/Abyssal Plain 4495m [3]

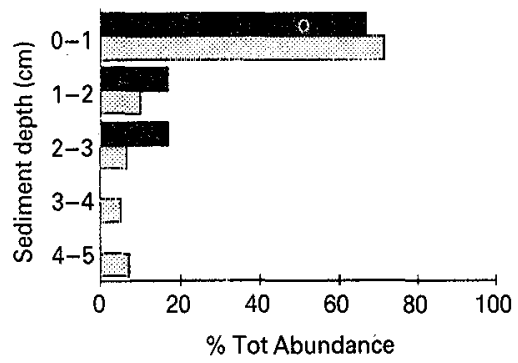

Figure 29 Individual vertical profiles percentage total abundance of copepods (black) and foraminifera (grey) for study areas 1, 2, 3 (cf. Table 1); number of observations in brackets. 


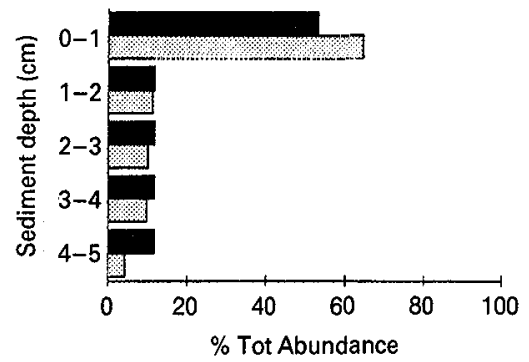

Biotrans 114 4560m [12]

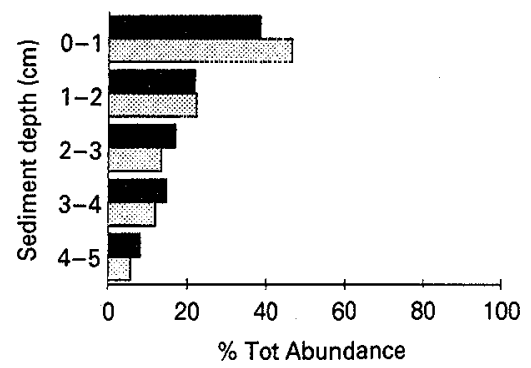

Madeira Abyssal Plain 4950m [23]

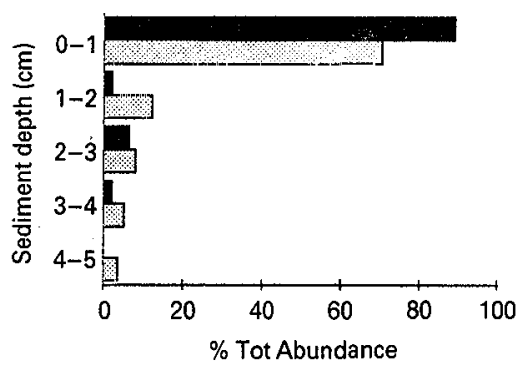

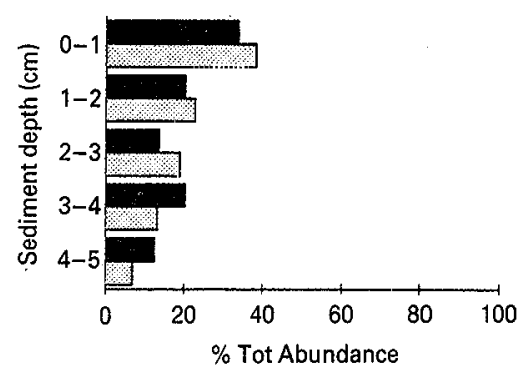

Biotrans 115 4560m [12]

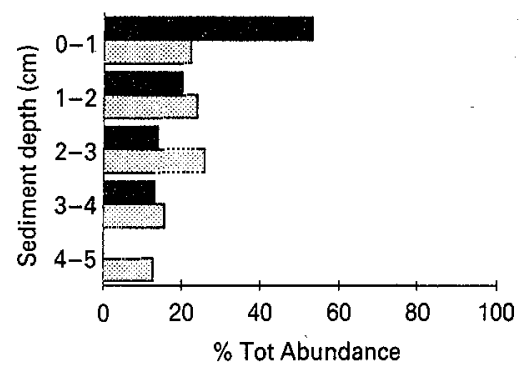

Madeira Abyssal Plain 5120m [23]

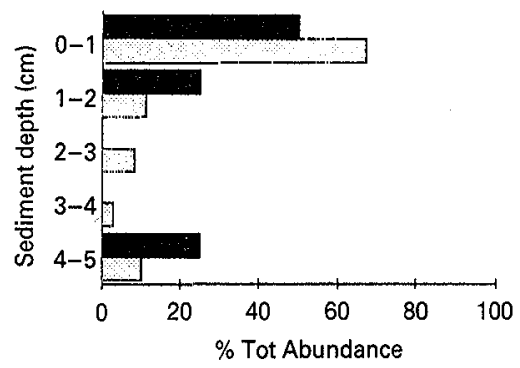

Figure 30 Individual vertical profiles percentage total abundance of copepods (black) and foraminifera (grey) for study areas 12 and 23 (cf. Table 1); number of observations in brackets. 
the sites were common to those recorded for metazoan meiofauna. Owing to the numerical abundance of nematodes compared with the other meiofaunal taxa, these profiles were similar to those for metazoan meiofauna but generally showed a lower percentage abundance in the surface centimetre of sediment and subsequent higher values in the deeper sediment layers due to the more superficial distribution of copepods and foraminifera. Five of the 20 profiles had between 40 and $50 \%$ of the nematodes in the top centimetre. A further five profiles were found to have $30-40 \%$ and four profiles to have $50-60 \%$ of total nematodes in the top centimetre of sediment.

Additional profiles from the Porcupine Abyssal Plain $(4850 \mathrm{~m})$ and Madeira Abyssal Plain ( $4856 \mathrm{~m}$ ) were not markedly different from those at previously described sites. The profile from the Madeira Abyssal Plain was very superficial with $>60 \%$ of individuals occurring in the surface centimetre of sediment and was similar to the profile at $5120 \mathrm{~m}$.

The profile from the DORA station (3958-4800 m) situated between the BIOTRANS and Iberian Sea stations showed a superficial distribution with $>50 \%$ of individuals occurring in the top centimetre of sediment and within the range of profiles described for the BIOTRANS and Iberic Sea stations.

\subsubsection{Copepods and Nauplii}

Vertical profiles for 11 sites at five of the designated study areas (see Table 1) are shown in Figures 29 and 30 . Five of the profiles showed more than $70 \%$ of individuals to be in the surface centimetre of sediment and only two profiles showed less than $50 \%$ of individuals in the surface centimetre. Sites from the Porcupine Seabight/Abyssal Plain area exhibited very superficial profiles. At $398 \mathrm{~m}, 98 \%$ of the copepods and nauplii occurred in the surface centimetre of sediment with none recorded below $2 \mathrm{~cm}$. The percentage abundance in the surface centimetre reduced with increasing depth but was still $>65 \%$ at the deepest site $(4495 \mathrm{~m})$. Percentage abundances were very low below $3 \mathrm{~cm}$ sediment depth and no individuals were found below this level at $4495 \mathrm{~m}$.

Profiles from sites at the BIOTRANS $(4538-4560 \mathrm{~m})$ station were, like those for metazoan meiofauna and nematodes, rather variable showing both rather superficial and more intermediate distributions. Penetration of copepods and nauplii was generally greater than in the Porcupine Seabight and Abyssal Plain.

On the Madeira Abyssal Plain, one site at $4950 \mathrm{~m}$ showed a very superficial vertical profile with $89.1 \%$ of individuals in the surface centimetre of sediment. The other site showed a less superficial profile 
but abundances $/ 10 \mathrm{~cm}^{2}$ were very low and it was likely that the observed profile was affected by mathematical limitations.

\subsubsection{Foraminifera}

Vertical profiles for 10 sites at five of the designated study areas (see Table 1) are shown in Figures 29 and 30. Seven of the profiles showed more than $60 \%$ of individuals to be in the surface centimetre of sediment. Sites from the Porcupine Seabight/Abyssal Plain showed very superficial vertical profiles similar to those for copepods and nauplii but with generally greater penetration to the deeper sediment depths. At $398 \mathrm{~m}$, $>80 \%$ of individuals were found in the surface centimetre of sediment; $>70 \%$ at $4495 \mathrm{~m}$ and $>60 \%$ at $1340 \mathrm{~m}$.

Sites at the BIOTRANS $(4538-4560 \mathrm{~m})$ station were again very variable with one site having a very superficial profile, two sites having a more intermediate profile and one site having a very deep profile with a subsurface maximum of $26 \%$ at the $2-3 \mathrm{~cm}$ sediment depth.

The two sites from the Madeira Abyssal Plain showed very superficial profiles with $>65 \%$ of individuals occurring in the surface centimetre.

\subsubsection{Multivariate analysis}

To gain an overview of any pattern in the distribution of the individual vertical profiles described above, the data were subjected to multivariate analysis by non-metric MDS (Field et al., 1982). Percentage total abundance data were used with the five sediment depths being treated as analogous to species. The data were first subjected to an arcsin transformation. The resulting two-dimensional ordinations were superimposed with the station numbers (see Table 1) and a series of symbols, the size of which was scaled to represent the values of a series of environmental parameters available for each station. The environmental parameters used were depth, degrees north, degrees west, distance off-shore, primary production and organic flux. The values for primary production were taken from the "Dahlem Map" (Berger, 1989) and values for organic flux were calculated using these data and the depth data according to the equation of Pace et al. (1987). Many of the environmental parameters used were either directly or indirectly correlated, for example depth and degrees west over some or all of the study areas.

The data for environmental parameters were used in conjunction with the percentage total abundance data for all samples at each sediment depth to calculate Spearman's rank correlation coefficients.

The MDS ordinations for each faunistic group are shown in Figures 

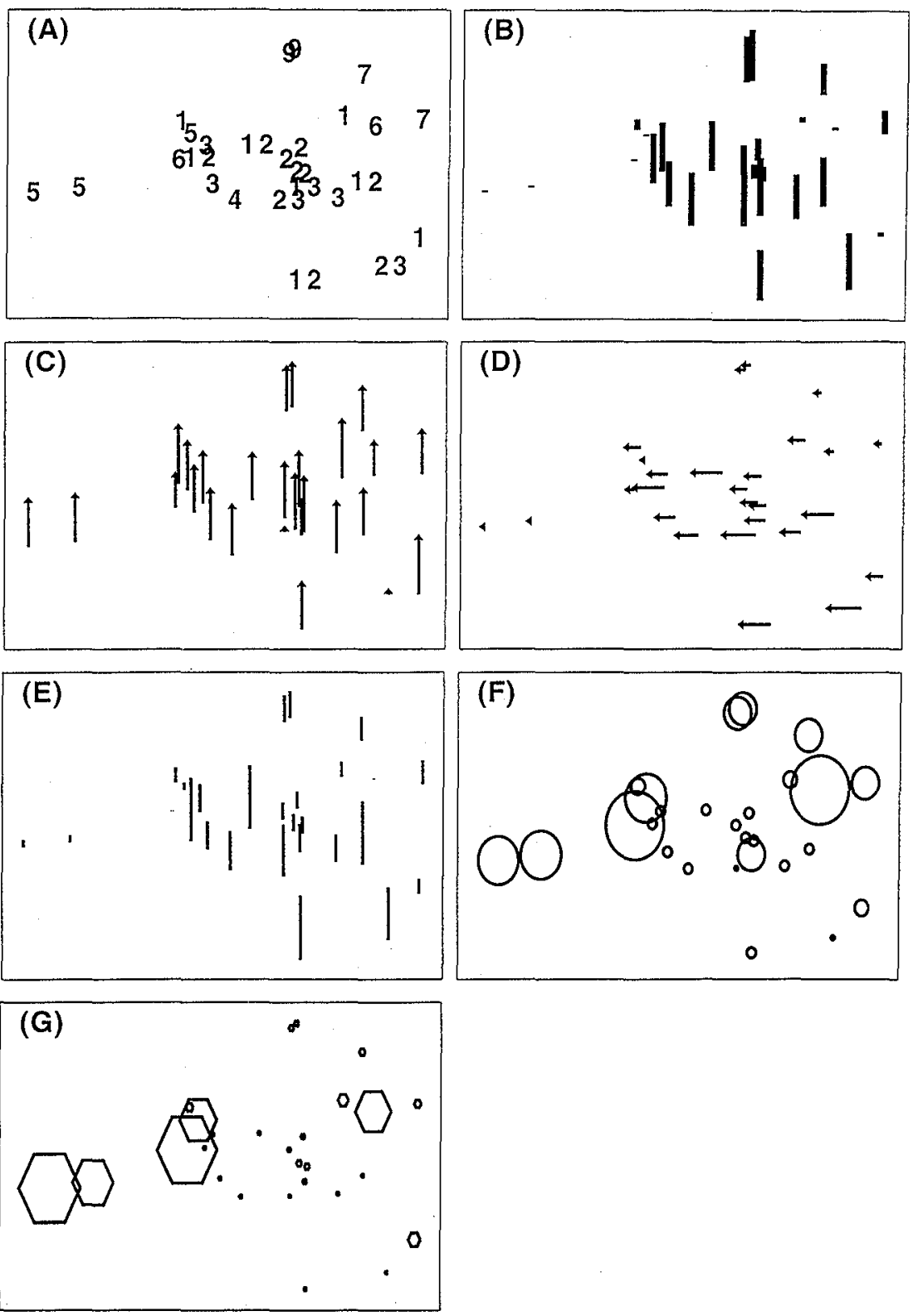

Figure 31 MDS ordination of root-root transformed metazoan meiofauna vertical profile data (percentage total abundance). Ordination superimposed with (A) station numbers and symbols scaled to show values of environmental parameters; (B) depth; (C) degrees north; (D) degrees west; (E) distance off-shore; (F) primary production; $(\mathrm{G})$ organic flux (area numbers: 1-2-3-4-5-6-79-12-23). 

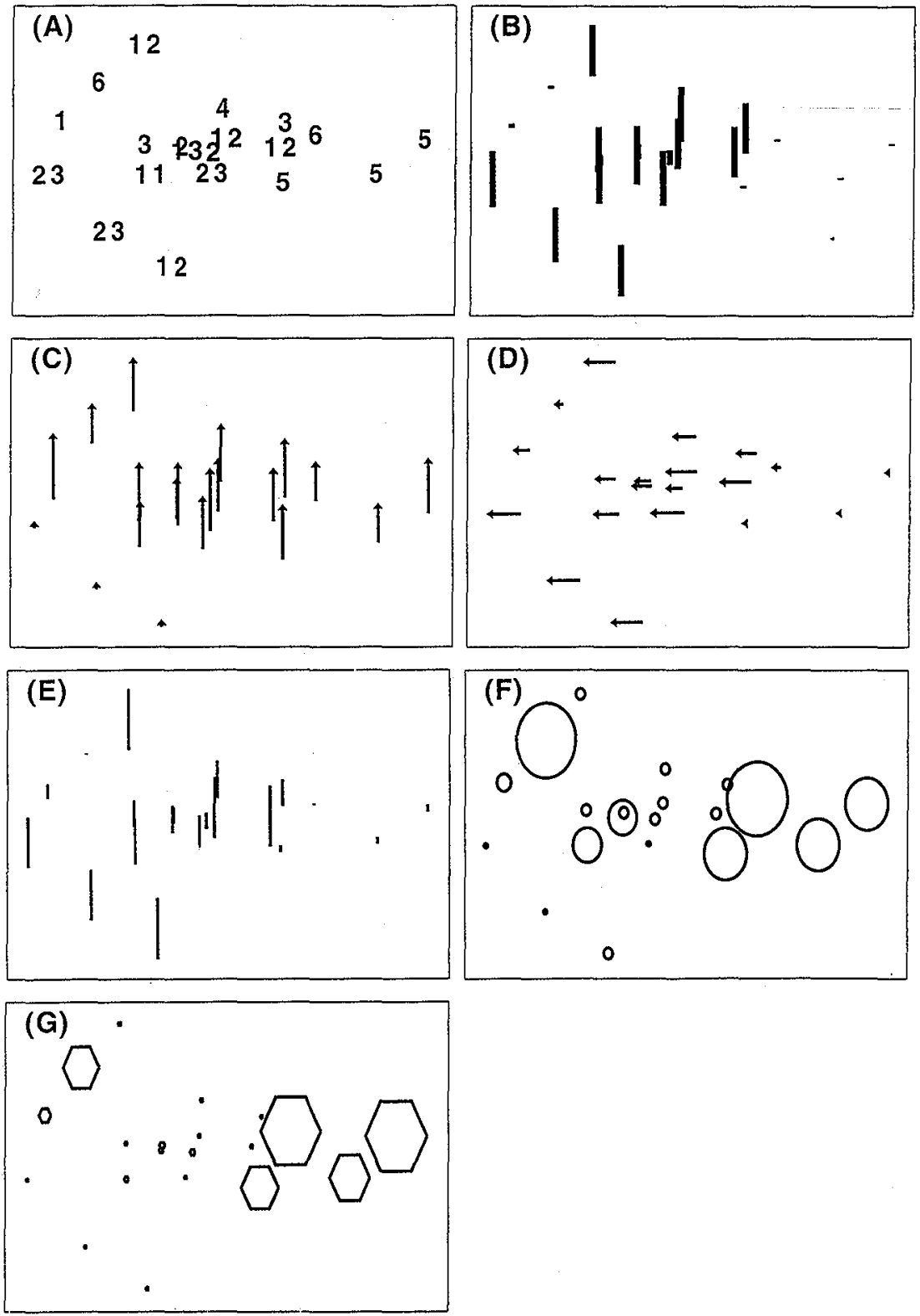

Figure 32 MDS ordination of root-root transformed nematode vertical profile data (percentage total abundance). Ordination superimposed with (A) station numbers and symbols scaled to show values of environmental parameters; (B) depth; (C) degrees north; (D) degrees west; (E) distance off-shore; (F) primary production; $(G)$ organic flux (area numbers: 1-2-3-4-5-6-12-23). 

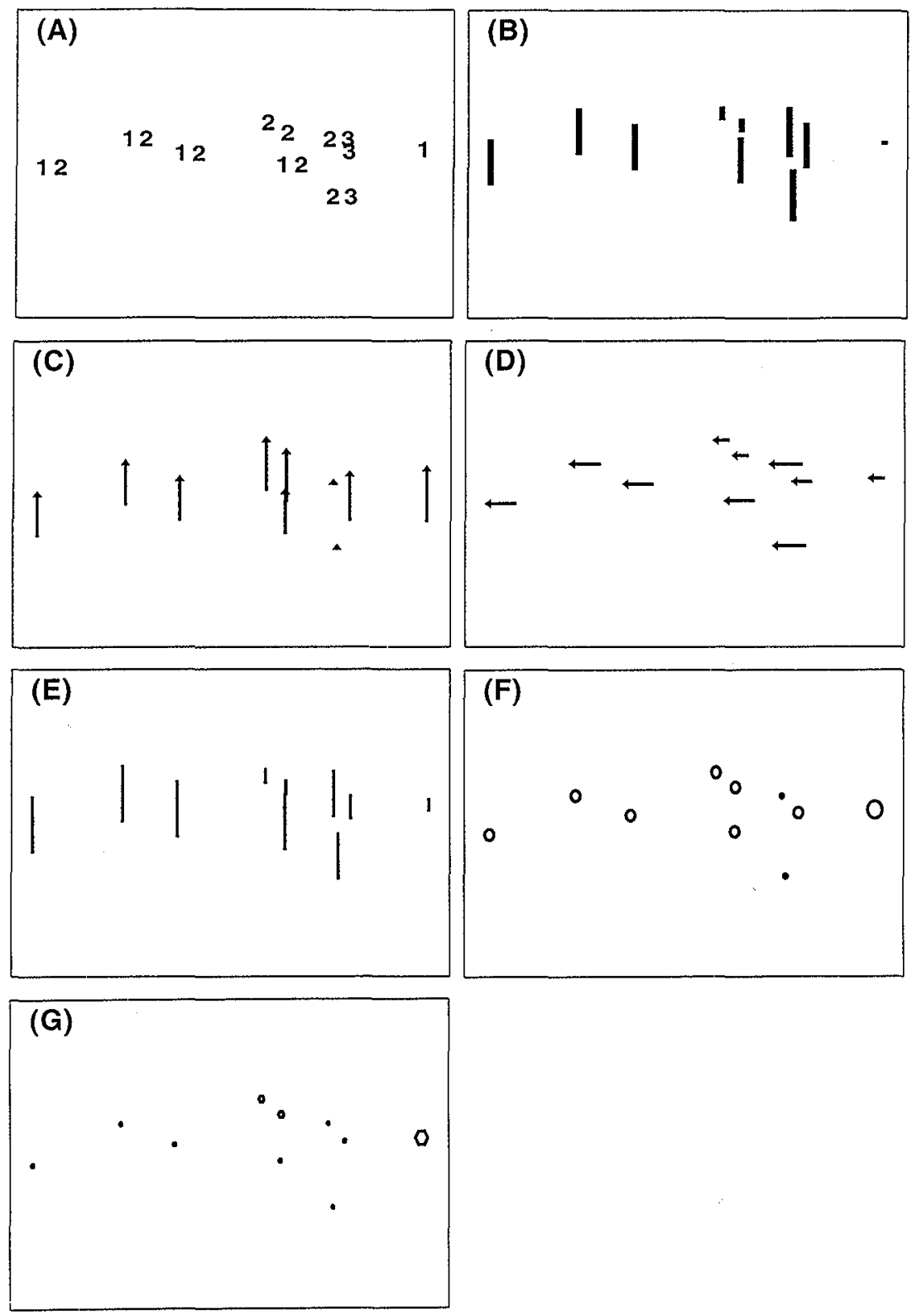

\section{( $F)$}

0
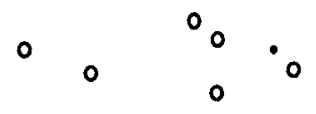

0

Figure 33 MDS ordination of root-root transformed copepod vertical profile data (percentage total abundance). Ordination superimposed with (A) station numbers and symbols scaled to show values of environmental parameters; (B) depth; (C) degrees north; (D) degrees west; (E) distance off-shore; (F) primary production; $(\mathrm{G})$ organic flux (area numbers: 1-2-3-12-23). 

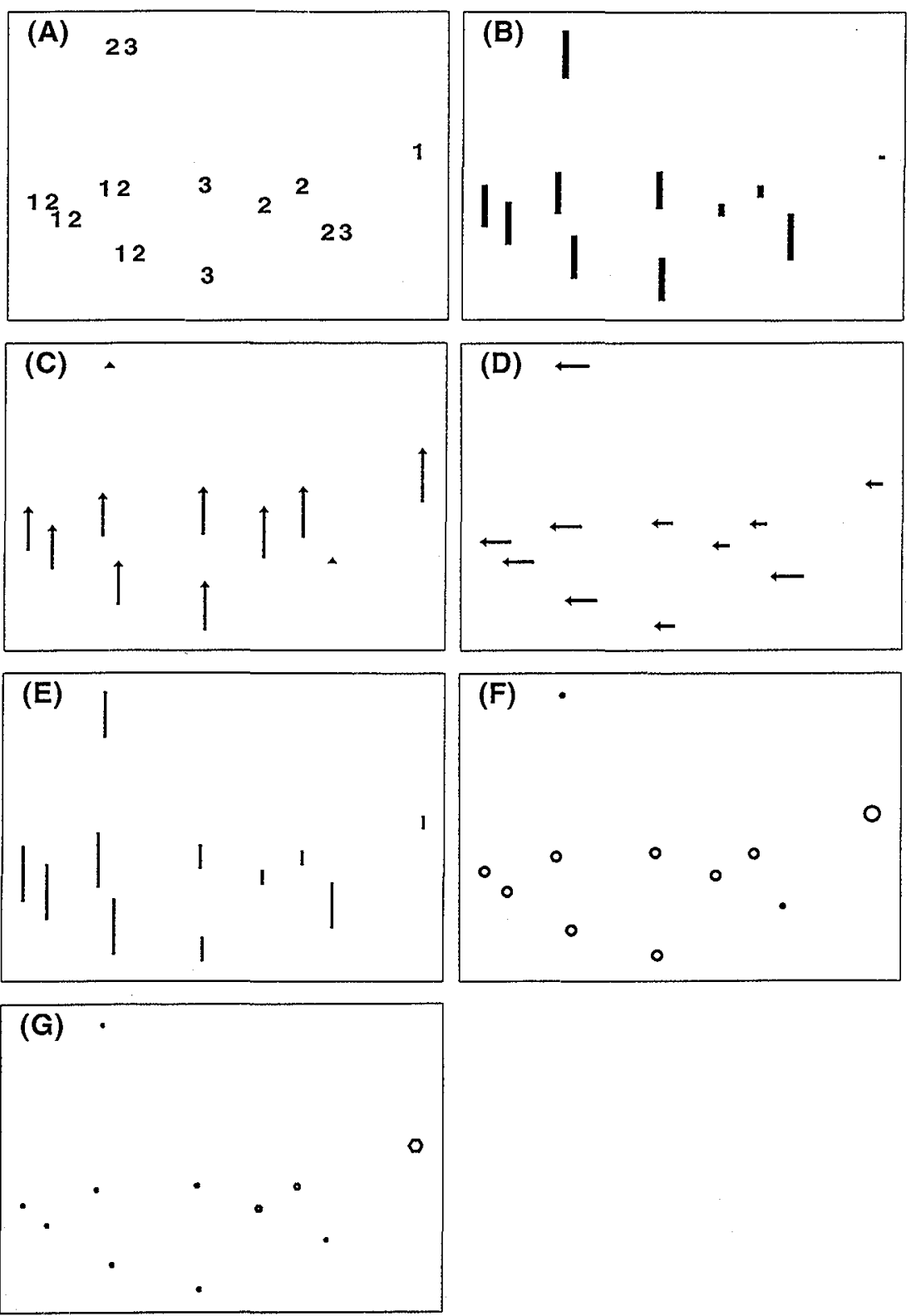

Figure 34 MDS ordination of root-root transformed foraminifera vertical profile data (percentage total abundance). Ordination superimposed with (A) station numbers and symbols scaled to show values of environmental parameters; (B) depth; (C) degrees north; (D) degrees west; (E) distance off-shore; (F) primary production; $(\mathrm{G})$ organic flux (area numbers: 1-2-3). 
31-34 (method explained in Clarke and Ainsworth, 1993). In general, a clear trend in the ordinations was seen from the most superficial profiles (sites at areas 1 and 23) to the deepest profiles at area 5 for metazoan meiofauna and nematodes and at area 12 for copepods and nauplii and foraminifera. Perhaps the most striking overall feature of the ordinations was found in those for the metazoan meiofauna and nematodes. Shallower sites having generally high organic flux and to a lesser extent, higher primary production and being closer to shore, appeared in the ordinations at both ends of the range of profiles. This indicated that similar environmental parameters could be associated with both superficial and deep vertical profiles. The ordinations superimposed with environmental characteristics did not show any strong overall trends. However, some local trends could be detected, especially in the metazoan meiofauna and nematode ordinations where more sites were available for analysis. In these ordinations, local trends were seen for increasingly superficial profiles in the Bay of Biscay shallower samples (area 5, $70-170 \mathrm{~m}$ and area $6,123-300 \mathrm{~m}$ ) as depth increased and organic flux decreased. Interestingly, sites at the deeper Bay of Biscay areas (7 and 9) showed a reversal of this trend. Another local gradient was seen in the increase in profile depth shown by metazoan meiofauna in sites at area 1 as depth increased from 398 to $960 \mathrm{~m}$ and organic flux decreased.

In all ordinations, the area 12 sites were fairly widely separated reflecting the high degree of variation in vertical profiles found at that station.

The ordinations for copepods and nauplii and foraminifera did not show any strong relationships with environmental parameters as the range of each parameter was rather small and fewer sites were available for analysis.

Spearman's rank correlation coefficients for each environmental parameter and faunistic group at the $0-1 \mathrm{~cm}$ sediment depths are shown in Table 7. A general observation was that when a significant positive correlation was found at the $0-1 \mathrm{~cm}$ sediment layer, significant negative correlations were found in the deeper sediment layers and vice versa. A degree of autocorrelation was thus apparent and results for deeper layers are therefore not shown for simplicity. A positive correlation at the 0-1 cm sediment depth indicated that profiles had become more superficial as the environmental parameter had increased and a negative correlation would indicate that profiles had become deeper as the environmental parameter had increased.

The results for metazoan meiofauna showed vertical profiles to be significantly positively correlated with depth and degrees west and significantly negatively correlated with primary production and organic flux. Nematodes showed a similar pattern but also showed a significantly negative correlation with degrees north. In both sets of results, the 
Table 7 Spearman rank correlation coefficients for metazoan meiofauna, nematodes, copepods and nauplii and foraminifera at $0-1 \mathrm{~cm}$ sediment depth against depth $(\mathrm{m})$, degrees north $(\mathrm{N} / \mathrm{S})$, degrees west $(\mathrm{E} / \mathrm{W})$, distance off-shore (DIST), primary production (PP) and organic flux (FLUX). N/S = not significant; ${ }^{*}=p<0.05 ;{ }^{* *}=p<0.01 ;{ }^{* * *}=p<0.001$.

\begin{tabular}{lcccccc}
\hline & \multicolumn{6}{c}{ Spearman rank correlations } \\
\cline { 2 - 7 } & Depth & N/S & E/W & DIST & PP & FLUX \\
\hline Metazoan meiofauna & 0.2737 & -0.0980 & 0.2832 & -0.0051 & -0.4733 & -0.2837 \\
Nematodes & $*$ & N/S & $*$ & N/S & $* * *$ & $*$ \\
& 0.3189 & -0.3335 & 0.2739 & 0.0432 & -0.2155 & -0.2126 \\
Copepods and nauplii & -0.7373 & 0.7214 & -0.6984 & -0.7768 & 0.2372 & 0.7366 \\
Foraminiferans & $* * *$ & $* * *$ & $* * *$ & $* * *$ & N/S & $* * *$ \\
& -0.2390 & 0.1994 & -0.1071 & -0.4497 & 0.0000 & 0.2014 \\
& N/S & N/S & N/S & N/S & N/S & N/S \\
\hline
\end{tabular}

correlations, although significant, were not particularly strong, generally being below \pm 0.35 .

Copepods and nauplii showed a complete reversal of the trends shown by metazoan meiofauna and nematodes being significantly negatively correlated with depth, degrees west and distance off-shore and significantly positively correlated with degrees north and organic flux. The correlation coefficients were generally much higher than for metazoan meiofauna and nematodes. However, there was no significant correlation with primary production. No significant correlations were found in the foraminifera data.

\subsubsection{Distributions below $5 \mathrm{~cm}$}

Few data are available describing the abundance of meiofauna at sediment depths below $5 \mathrm{~cm}$ in the northeast Atlantic. Dinet and Vivier (1977) comment that although in their study, $90 \%$ of all meiofauna were found in the surface $4 \mathrm{~cm}$ of sediment, the deeper sediment layers are by no means azoic Rutgers van der Loeff and Lavaleye (1986) reported that approximately $10 \%$ of total meiofauna was found below $6 \mathrm{~cm}$ depth and were found down to $20 \mathrm{~cm}$. Lambshead and Ferrero (unpublished data) also recorded nematodes down to $20 \mathrm{~cm}$ sediment depth in samples from the Porcupine Abyssal Plain and in one core found that almost $25 \%$ of individuals occurred below the $5-\mathrm{cm}$ horizon.

\subsubsection{Discussion}

The vertical distribution of meiofauna in the northeast Atlantic agrees with the generally observed fact that abundances are generally highest in 
the surface layers of sediment and decrease with increasing depth, such that approximately $90 \%$ of individuals may be found within the top $5 \mathrm{~cm}$ of sediment. This result, though unremarkable in itself, is significant in terms of the choice of core depth chosen to sample adequately the meiofaunal component of the benthos. Thus, for many studies it may be adequate to sample only to a depth of $5 \mathrm{~cm}$, thus reducing the amount of sediment to be processed for each sample. This is a most important factor as the processing of meiofauna samples is an extremely lengthy operation and is often the limiting factor in the choice of sample replicates for a given site. In many cases, the increase in statistical robustness afforded by taking more replicates would more than outweigh any drawbacks associated with accepting a sampling efficiency of $90 \%$.

In the intertidal and shallow waters, it is generally agreed that oxygen is the single most important factor in determining the vertical distribution of meiofaunal organisms. However, as has been noted earlier in this chapter, oxygen is not normally a limiting factor for meiofauna over the surface $5-10 \mathrm{~cm}$ and oxygen has previously been shown to control only the maximum penetration depth of the meiofauna (Shirayama, 1984b).

In this review, meiofaunal vertical profiles were found to be correlated with a number of different environmental parameters. However, some care is required when assuming the independence of the parameters chosen. A brief study of the "Dahlem" map of surface primary production shows that, over the study area as a whole, the physical and geographical parameters (depth, degrees north, degrees west and distance off-shore) could all be taken as being correlated to some extent with surface primary production and thus organic flux. Therefore, if any overall conclusion may be drawn it is that food supply to the sediment was identified as a significant factor in determining the vertical distribution of meiofauna within the sediment.

This conclusion agrees to some extent with the findings of other studies in the northeast Atlantic which have supplied data for this review. Pfannkuche (1985) found a strong correlation between CPE and vertical distribution patterns of meiofauna. Vanreusel and Vincx (unpublished) found on the basis of correlations with chlorophyll-a and bacteria (food) and nitrate concentration (sediment oxygenation) that food levels were significant in determining the vertical profiles of meiofauna but that lower oxygen levels in the deeper layers of fine sediments could limit this effect. These authors found a strong correlation between meiofauna vertical profiles and both bacterial densities and nitrate concentration at sites in the Porcupine Seabight. However, Dinet and Vivier (1977) suggested that sediment water content was significant in controlling the depth of penetration of meiofauna into the sediment and Rutgers van der Loeff and Lavaleye (1986) associated a small subsurface peak in nematode 
biomass with the presence of a boundary layer between soft sediments overlying a more compact clay.

These conclusions from studies in the northeast Atlantic agree with studies from elsewhere in the world's deep oceans where meiofauna vertical profiles have been correlated with food availability (e.g. Thiel, 1983; Shirayama, 1984b; Tietjen et al., 1989) and sediment water content (e.g. Snider et al., 1984; Jensen et al., 1992).

Therefore, it seems likely that the vertical profiles of meiofauna in the deep sea are not controlled by one factor but may be a combination of factors such as food supply and sediment characteristics. This may help to explain why in this study, although a rather general correlation was found between food supply and vertical profiles, individual localized gradients (as shown by the MDS analysis) may differ in response under the influence of other factors. Thus, differences in sediment characteristics could explain the appearance of relatively shallow, high food supply sites in the Bay of Biscay (areas 5 and 6) and the Porcupine Seabight (area 1) at the extremes of the vertical distributions found over the study area.

The basic tendency for biological systems to be variable is demonstrated by the wide range of vertical profiles found in the four sites at the BIOTRANS station (area 12). At this station, the sediment is subject to a seasonal input of phytodetritus from the overlying surface water. The phytodetritus forms a rather patchy resource on a small scale being concentrated in hollows and around biogenic structures but also displays patchiness on a larger scale occurring in different quantities at different parts of the BIOGAS station (Thiel et al., 1989-90). Thus, a basic correlation with food supply may still exist but food supply may be variable over medium scales in a stochastic fashion.

The difference in response found between metazoan meiofauna and nematodes and copepods and nauplii may be the result of a behavioural response such that copepods adopt a more epibenthic lifestyle in the presence of an increased food supply, whereas the metazoan meiofaunaprincipally nematodes-may be better adapted to exploit increased food resources deeper in the sediment. Tietjen et al. (1989) observed a similar discrepancy between the responses of nematodes and copepods to decreasing bacterial densities in the sediment. In their study on the Hatteras Abyssal Plain, nematode densities decreased with depth as bacterial densities decreased. However, in this case, copepod densities increased with depth. The authors ascribed this discrepancy to the high abundance of particularly large and robust burrowing copepods at the site which could more easily penetrate the deeper sediment depths.

Another factor which may control vertical profiles of meiofauna in the deep sea is the role of interspecific and macro-meiofauna interactions. Gooday (1986a) provides some data for foraminiferans showing that 
different species can have very different vertical profiles and discusses other possible interactions in detail. Pfannkuche and Thiel (1987), quoting Hansen (1978), commented that predation on the meiofauna by holothuroideans and sipunculids may have an impact on vertical distributions. Tietjen et al. (1989) also found that high rates of bioturbation increased food supply to the deeper sediment layers and that this was reflected by deeper vertical distributions of meiofauna. The importance of such interactions should not be overlooked although they may be technically difficult to study.

Finally, the results of the comparison of sampling gear given earlier in this review have important implications for future studies of vertical profiles in the deep sea. It appears that box corer samples must be viewed with some caution due to their demonstrated tendency to reduce meiofaunal numbers in the surface sediment layers. Therefore, until superceded, the multicorer should be regarded as the sampling equipment of choice for this type of study.

\section{TEMPORAL PATTERNS}

In boreal areas, the communities inhabiting shallow water sediments are closely coupled to seasonal variations in phytoplankton primary production (reviewed by Graf, 1992). For example the spring and autumn phytoplankton blooms in the Kiel Bight are followed by a rapid increase in heat production, oxygen consumption and electron transport system activity and by an increase in bacterial and foraminiferal biomass due to growth and reproduction (Graf et al., 1982, 1983; Altenbach, 1992). The evidence for a similar response by the metazoan meiobenthos is limited and equivocal (Graf et al., 1982). At depths of 30-35 m on the Alaskan shelf, the sedimentation of the spring phytoplankton bloom apparently did not influence the abundance of major metazoan meiobenthic taxa, either seasonally or interannually (Fleeger et al., 1989). However, reproduction in two abundant harpacticoid species did appear to be linked in some way to phytoplankton sedimentation events (Fleeger and Shirley, 1990). Deep-sea meiobenthic communities show similar dynamic characteristics. Although Gooday (1988) and Pfannkuche (1993b) illustrated a pronounced response of deep-sea foraminiferans to aggregated phytodetritus deposition following the phytoplankton blooms in particular areas of the northeast Atlantic (Billet et al., 1983), as yet there is no equivalent evidence for any metazoan taxon (Gooday, 1988; Graf, 1992; Pfannkuche, 1993b). It is mainly the smaller benthic size groups (bacteria, protozoans) that react strongly to POM pulses, emphasizing their particular importance to sediment-water interface flux rates. 
At bathyal depths in the Norwegian Sea, certain benthic foraminifera display a very rapid physiological response to organic matter inputs (Linke, 1992) and also a feeding response which leads, within days, to a biomass increase (Altenbach, 1992). Abyssal foraminifera that colonize and feed on phytodetritus probably undergo rapid growth and reproduction, as do species living in the organically enriched, bathyal San Pedro Basin (Corliss and Silva, 1992). At the BIOTRANS site, Pfannkuche et al. (1990) and Pfannkuche (1992, 1993b) observed that the foraminiferal meiobenthos switched from being less abundant (around 40\%) than the metazoan meiobenthos in March and May to being more abundant $(60-70 \%)$ after the deposition of phytodetritus in July. The numerical abundance of the metazoan meiobenthos and their vertical distribution profiles remained stable following the 1982 phytodetritus sedimentation event in the Porcupine Seabight (areas 1-3). It appears that the foraminiferal meiobenthos are more dynamic than the metazoans, at least in terms of their response to organic matter inputs.

In areas with pronounced seasonality in the supply of organic matter to the seafloor, the timing of sampling is of great importance. Previous attempts to demonstrate temporal variability in faunal composition may have failed mainly because of inadequate sampling. Recently, de Bovée $e t$ al. (1990) found changes in taxonomic composition at deep stations (2105-2367 m) in the NW Mediterranean between summer and autumn. With increasing sediment pigment content, representing the quantitative food supply to the benthos from planktonic primary production (Thiel, 1978), nematode percentages decrease in autumn, while all other metazoan taxa increase in relative abundance. Even in open oceanic regions where seasonal detritus input occurs, there is evidence of temporal variability in faunal composition (Pfannkuche et al., 1990).

\section{SUMMARY AND CONCLUSIONS}

The ecology of the meiobenthos in the deep northeast Atlantic is reviewed from published accounts and new data collected in a cooperative European research effort funded by the CEC MAST programme.

Data on the protozoan and metazoan meiobenthos from various sampling stations in the northeast Atlantic $\left(15-53^{\circ} \mathrm{N}\right.$, continental margin to Mid-Atlantic Ridge) have been compiled. For the purposes of the review these data are arranged into 30 study areas based on geographical and bathymetric proximity $(<1000 \mathrm{~m}, 1000-3000 \mathrm{~m}, 3000-4500 \mathrm{~m}$, $>4500 \mathrm{~m}$ ) of the original sampling stations.

A variety of techniques have been used for the collection and processing of deep-sea meiobenthos samples; in some cases this has 
produced a degree of bias in the results (see Bett et al., 1994). Following Thiel (1993), we suggest that standard procedures should be adopted, for example the use of a multiple corer for sample collection, and a $31 \mu \mathrm{m}$ sieve mesh as the lower limit for meiobenthos.

The environment of the deep northeast Atlantic is also reviewed in terms of those variables that may exert an important influence on the distribution of the benthos, for example sediment type, sediment oxygen concentrations, availability of organic matter, bottom water masses, and near-bottom currents.

The density of meiobenthos generally decreases with water depth. This appears to be true for the meiobenthos as a whole and for individual component taxa. This general trend, however, is complicated by a number of local/regional influences, for example upwelling areas, elevated near-bottom currents, and sedimentology. In contrast to density, the contribution of major taxa to the meiobenthos appears to be influenced only slightly by water depth. Among the metazoans, nematodes tend to be relatively most abundant in samples from the deepest stations, while other taxa reach their highest relative abundances at the shallowest stations.

Examination of latitudinal variation in density of meiobenthos suggests that there is, to some degree, a relationship between surface primary production and density. Corresponding variations in the composition of major taxa are minimal.

Multivariate analyses of taxon densities confirm the importance of water depth and surface primary production. Together, these two factors exert considerable control on the supply of organic matter to the seafloor and presumably the densities of meiobenthic taxa. Corresponding analyses of major taxon composition did not reveal any general trends in the data, though local factors (e.g. sediment type) do clearly influence taxon composition.

Comparisons of meiobenthos densities from the northeast Atlantic with other areas also suggest a link with surface primary production (and potentially water temperatures). By comparison to the northeast Atlantic, densities are lower in the western Atlantic, Mediterranean, and eastern Pacific, where surface primary production is generally lower, and densities are higher in the northern Atlantic, where production is higher.

There have been few studies of the meiobenthos at the lower taxonomic levels (family, genus, species) in the deep northeast Atlantic. The available data suggest that nematode, copepod and foraminiferal assemblages have a high diversity, both in terms of high species richness and low dominance. This is in accord with the emerging view of the deep-sea floor as a generally high diversity environment (e.g. Grassle and Maciolek, 1992). Family and genus level comparisons of the nematode 
communities from western and eastern Atlantic locations indicate many similarities. The occurrence of parallel nematode communities in fine shelf and coastal sediments (e.g. Heip et al., 1985) may extend to the fine sediments of the deep sea.

Small-scale (centimetres) spatial variation in the environment of the deep-sea floor is thought to play an important role in many biological processes (e.g. Rice and Lambshead, 1993). Small-scale variation in the meiobenthos has, to date, received little attention in the deep northeast Atlantic. It is, however, clear that at those sites where significant phytodetritus deposition occurs (e.g. areas $1-4,12$ ), the patchy distribution of this organic material over the seafloor influences the distribution of the benthos, particularly the foraminiferal meiobenthos.

The vertical distribution of meiofauna in the northeast Atlantic agrees with the generally observed fact that abundances are generally highest in the surface layers of sediment and decrease with increasing depth. In general, copepods and foraminiferans were distributed somewhat more superficially than nematodes and total metazoa. Multivariate and correlation analysis showed that food supply and sediment characteristics were significant factors in determining the vertical distribution of meiofauna within the sediment but the role of oxygen concentrations, often of most importance in intertidal and shallow sediments, was not identified as significant.

As approximately $90 \%$ of all individuals were found in the top $5 \mathrm{~cm}$ of sediment, it may be adequate to sample only to this depth, thus reducing the amount of sediment to be processed for each sample. The differences identified in sample quality between various sampling devices could affect recorded vertical profile data and thus the multiple corer is suggested as the equipment of choice.

Temporal variation in deep-sea meiobenthos has been studied at only a few sites. It occurs most notably at those locations which experience a highly seasonal input of phytodetritus (e.g. areas $1-4,12$ ). The biological response to seasonal phytodetritus deposition is particularly marked in certain opportunist foraminiferal species, and may also be detected in small metazoans (e.g. nematodes).

Overall, the importance of the supply of organic matter to the seafloor in determining the distribution of deep-sea meiobenthos is clear. Its influence is apparent at all spatial scales: in global comparisons of oceanic regions, across regional gradients in surface primary production and water depth, in the local influences of upwelling, near-bottom currents and sediment type, and in the small-scale patchy distribution of organic matter on the seafloor. Corresponding temporal variations are less well known; in the case of organisms which exploit phytodetritus, these could range from hourly variation due to tidal redistribution, to the 1-year 
deposition cycle, and potentially to much longer geological time-scales (see Smart et al., 1994) reflecting changes in ocean climate.

Meiobenthic organisms provide an ideal tool with which to improve our understanding of the structure and function of the deep-sea benthic ecosystem. In practical terms this faunal component can be sampled with a multiple corer, an extremely reliable device that collects high-quality samples suited to a number of studies (biological, physical and chemical). The comparatively high abundance and diversity make the deep-sea meiobenthos ideally suited to quantitative studies and suggest that this group plays an important role in ecological processes. To date most studies have concentrated on larger-scale structural characteristics, and although complicated by the lack of a standard protocol, the relatively simple data on the densities of major taxa obtained show clear relationships with environmental variables. There is, nevertheless, a need for smaller-scale structural studies and process/function studies generally. Improved taxonomic resolution, work at the genus and species level, coupled with studies at smaller physical scales, will enable the factors controlling community structure to be examined in more detail. One area of current interest is the high diversity (and its maintenance) of deep-sea benthos, an understanding of which is likely to require a knowledge of ecology in "patchy" environments. Meiobenthos can be sampled at the physical scales (centimetres) on which seafloor patchiness is likely to operate. At both large and small scales, process studies addressing energy and nutrient fluxes are now a dominant theme in biological oceanography. Given that members of the deep-sea meiobenthos are likely to play a significant role in these processes, that they are especially amenable to quantitative study, and that they appear to be more responsive (particularly the foraminiferal component) to variations in the input of organic matter to the seafloor than members of larger benthic size categories, the meiobenthos should be a key target group for any benthic process study. While many of the issues mentioned above can be addressed by general sampling programmes or through directed sampling as "natural experiment" some problems can only be tackled using a formal experimental or manipulative approach. The practical and logistic problems of deep-sea experimentation, either in situ or ship-board, favour the use of small "observational units". This should prompt the use of meiobenthos as the most appropriate research tool.

\section{ACKNOWLEDGEMENTS}

The authors acknowledge the CEC-MAST programmes 0037-C(EDB) and MAS2-CT92-0033 for the major part of the financial support. Also 
the Belgian National Science Foundation (FKFO 32.0094.92) and the University of Gent, Belgium (supporting project Concerted Actions 92/98-08) are greatly acknowledged. We are also grateful to Dr K. Hostens for the preparations of several figures on computer.

\section{REFERENCES}

Aller, J.Y. and Aller, R.C. (1986). Evidence for localized enhancement of biological activity associated with tube and burrow structures in deep-sea sediments at the HEBBLE site, western North Atlantic. Deep-Sea Research 33, 755-790.

Alongi, D. M. (1992) Bathymetric patterns of deep-sea benthic communities from bathyal to abyssal depths in the western South Pacific (Solomon and Coral Seas). Deep-Sea Research 39, 549-566.

Alongi, D.M. and Pichon, M. (1988). Bathyal meiobenthos of the western Coral Sea: distribution and abundance in relation to microbial standing stocks and environmental factors. Deep-Sea Research 35, 491-503.

Altenbach, A V. (1992). Short term processes and patterns in the foraminiferal response to organic flux rates. Marine Micropaleontology $19(\mathbf{1} / \mathbf{2}), 119-129$.

Apostolescu, V., Montarges, M and Wanneson, J. (1978). Morphologie, structure et sediments de l'Atlantique-Nord (Étude bibliographique). Institute Francais du Petrole, Division Geologie, Report $22.328,54 \mathrm{pp}$.

Auffret, G. (1985), Environnement morphologique et sédimentologique. In "Peuplements profonds du Golfe de Gascogne" (L. Laubier and C. Monniot, eds), pp. 43-70. IFREMER, Paris.

Barnett, P.R.O., Watson, J. and Connelly, D. (1984). A multiple corer for taking virtually undisturbed samples from shelf, bathyal and abyssal sediments. Oceanologica Acta 7, 399-408.

Berger, W H. (1975) Deep-sea carbonates: dissolution profiles from foraminiferal preservation. Cushman Foundation for Foraminiferal Research Special Publication 13, 82-86.

Berger, W. H. (1989) Global maps of ocean productivity. In "Productivity of the Ocean: Past and Present" (W.H. Berger, V.S. Smetacek and G. Wefer, eds), pp. 429-455. Dahlem Workshop Reports, Life Sciences Research Report $\mathbf{4 4}$ John Wiley, Chichester.

Berger, W. H., Fischer, F , Lai, $C_{n}$ and Wu, G (1988). OCEAN carbon flux: global maps of primary production and export. In "Biogeochemical Cycling and Fluxes Between the Deep Euphotic Zone and Other Oceanic Realms" (Agrian ed.), pp. 131-176. NOAA National Underseas Research Program, Research Report 88-1.

Bett, B., Vanreusel, A., Vincx, M., Soltwedel, T., Pfannkuche, O., Lambshead, P.J.D., Gooday, A.J., Ferrero, T and Dinet, A. (1994) Sampler bias in the quantitative study of deep-sea meiobenthos. Marine Ecology Progress Series 104, 197-203.

Billett, D.S.M., Lampitt, R.S., Rice, A.L. and Mantoura, R.F.C. (1983). Seasonal sedimentation of phytoplankton to the deep-sea benthos. Nature, London 302, 520-522. 
Biscaye, P.E., Kolla, V., and Turekian, K.K. (1976). Distribution of calcium carbonate in surface sediments of the Atlantic Ocean. Journal of Geophysical Research 81, 2595-2603.

Blomqvist, S. (1991). Quantitative sampling of soft-bottom sediments: problems and solutions. Marine Ecology Progress Series 72, 295-304.

Bodin, P (1968). Copépodes harpacticoides des étages bathyal et abyssal du Golfe de Gascogne. Mémoires du Muséum National d'Histoire naturelle, Paris, Series A, Zoologie 55 (1), 1-107.

Brady, H.B (1884). Report on the Foraminifera dredged by H.M.S. Challenger during the years 1873-1876. Reports of the Scientific results of the Voyage of the H.M.S. Challenger 9 (Zoology), 1-814.

Carney, R.S., Haedrich, R.L and Rowe, G.T. (1983). Zonation of Fauna in the Deep Sea. In: "Deep-Sea Biology" (G.T. Rowe, ed.) 8, 371-399. John Wiley, London.

Cartwright, N.G. (1988). Biological and ecological studies on Benthic Foraminifera from the Bathyal and Abyssal Northeast Atlantic. PhD Thesis: University of Reading.

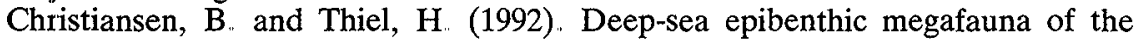
northeast Atlantic and biomass at three mid-oceanic locations estimated from photographic transects. In "Deep-Sea Food Chains and the Global Carbon Cycle" (G.T. Rowe and V. Pariente, eds), pp. 125-138. Kluwer, Dordrecht.

Clarke, K R and Ainsworth, M. (1993) A method of linking multivariate community structure to environmental variables. Marine Ecology Progress Series, 92, 205-219.

Corliss, B.H. and Chen, C. (1988) Morphotype patterns of Norwegian deep-sea benthic foraminifera and ecological implications. Geology 16, 716-719.

Corliss, B.H. and Silva, K (1992) . Rapid growth of deep-sea benthic foraminifera from the San Pedro Basin, California " Program \& Abstracts, Fourth International Conference on Paleoceanography, 21-25 September 1992, Kiel, Germany, pp. 88-89.

Coull, B.C. (1988) Ecology of marine meiofauna. In "Introduction to the Study of Meiofauna" (R.P. Higgins and H. Thiel, eds), pp. 18-38. Smithsonian Institution Press, Washington, DC

Coull, B.C., Ellison, R.L., Fleger, J.W. , Higgins, R.P., Hope, W. D., Hummon, W.D., Rieger, R.M., Sterrer, W.E., Thiel, H. and Tietjen, J.H. (1977) Quantitative estimates of the meiofauna from the deep-sea off North Carolina, USA. Marine Biology 39, 233-240.

de Bovée, F., Guidi, L and Soyer, J. (1990). Quantitative distribution of deep-sea meiobenthos in the North occidental Mediterranean basin (Gulf of Lions). Continental Shelf Research 10, 1123-1145

Decreamer, W (1983). Five new species of deep-sea desmoscolecids (NematodaDesmoscolecida) from the Bay of Biscay. Bulletin de l'Institut royal de Science naturelle de Belgique, 55, 1-26.

Desbruyères, D , Deming, J W., Dinet, A and Khripounoff, A (1985) Réactions de l'écosystème profund aux perturbations: nouveaux résultats expérimentaux In "Peuplements profonds du Golfe de Gascogne" (L. Laubier and C. Monniot, eds), pp. 121-142. IFREMER, Paris.

Dickson, R.R. and Kidd, R.B. (1987). Deep circulation in the Southern Rockall Trough - the oceanographic setting of site 610 . Initial Reports of the Deep Sea Drilling Program, 9A, 1061-1074.

Dickson, R. R., Goulds, W.J., Medler, K.J. and Gmitrowicz, E.M. (1986). 
Seasonality in currents of the Rockall Channel Proceedings of the Royal Society of Edinburgh $(B)$ 88, 103-125.

Dinet, A. (1973). Distribution quantitative du méiobenthos profond dans la région de la dorsale Walvis (Sud-Ouest Africain). Marine Biology 20, 20-26.

Dinet, A. (1976). Etude quantitative du méiobenthos dans le secteur nord de la Mer Egée. Acta Adriatica 18, 83-88.

Dinet, A. (1977). Données quantitative sur le méiobenthos bathyal de la Mer de Norvège. Pages 13-14. In "Géochimie Organique des Sédiments Marine Profond. Orgon I, Mer de Norvège, Aout, 1974". CEPM-CNEXO, Comité Etudes Geo-Chim, Mar, (R Pelet and A Combaz, eds) CNRS, Paris.

Dinet, A. (1979). A quantitative survey of meiobenthos in the deep Norwegian Sea. Ambio Special Report 6, 75-77.

Dinet, A. (1981). Description de deux nouvelles espèces abyssales de Pontostratiotes (Crustacea, Copepoda, Harpacticoida). Bulletin de la Société zoologique de France 106, 201-211.

Dinet, A. (1985). Répartition du genre Pontostratiotes (Copepoda, Harpacticoida). In "Peuplements profonds du Golfe de Gascogne" (L. Laubier and C. Monniot, eds), pp. 419-424. IFREMER, Paris.

Dinet, A and Khripounoff, A (1980). Rapports quantitatifs entre le meiobenthos et la matière organique en zone abyssale. In "Colloques Internationaux du C.N.R.S no 293. Biogéochimie de la matière organique à l'interface eausédiment marin" (R. Dumas, ed), pp. 319-324. CNRS, Paris.

Dinet, A and Vivier, M.H (1977). Le méiobenthos abyssal du Golfe de Gascogne. I. Considération sur les données quantitatives. Cahiers de Biologie Marine 18, 85-97.

Dinet, A and Vivier, M.H. (1979). Le méiobenthos abyssal du Golfe de Gascogne. II. Les peuplements de nématodes et leur diversité spécifique. Cahiers de Biologie Marine 20, 109-123.

Dinet, A and Vivier, M.H. (1981). Ajustement de la loi de Motomura aux peuplements nématologiques abyssaux du Golfe de Gasgogne. Téthys 10, 141-148.

Dinet, A., Laubier, L., Soyer, J and Vitiello, P. (1973). Resultats biologiques de la Campagne Polymede II Le méiobenthos abyssal. Rapport de la Commission Internationale pour l'Exploration de la Mediterranee 21, 701-704.

Dinet, A., Desbruyères, $D$. and Khripounoff, A. (1985). Abondance des peuplements macro- et méiobenthiques: répartition et stratége d'échantillonnage. In "Peuplements profonds du Golfe de Gascogne" (L Laubier and C. Monniot, eds), pp. 121-142. IFREMER, Brest

Embley, R.W. (1976). New evidence for debris flow deposits in the deep-sea. Geology 4, 371-374.

Emery, K.O and Uchupi, E. (1984). "The Geology of the Atlantic Ocean". Springer, New York.

Field, J G, Clarke, K R. and Warwick, R.M. (1982). A practical strategy for analysing multispecies distribution patterns. Marine Ecology Progress Series 8, $37-52$.

Fleeger, J.W and Shirley, T.C. (1990). Meiofaunal responses to sedimentation from an Alaskan spring bloom. II Harpacticoid population dynamics. Marine Ecology Progress Series 59, 239-247.

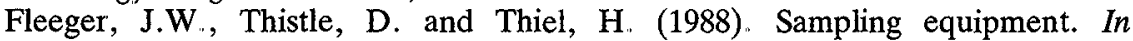
"Introduction to the Study of Meiofauna" (R.P. Higgins and H. Thiel, eds), pp. 115-125. Smithsonian Institution Press, Washington, DC. 
Fleeger, J.W, Shirley, T.C. and Ziemann, D.A. (1989). Meiofaunal responses to sedimentation from an Alaskan spring bloom. I. Major taxa. Marine Ecology Progress Series 51, 131-145.

Gage, J.D. and Tyler, P. A (1991). "Deep-Sea Biology. A Natural History of Organisms at the Deep-Sea Floor" "Cambridge University Press, Cambridge.

Gooday, A.J (1986a). Meiofaunal foraminiferans from the bathyal Porcupine Seabight: size structure, taxonomic composition, species diversity and vertical distribution in the sediment. Deep-Sea Research 33, 1345-1372.

Gooday, A.J. (1986b). Foraminifera in meiofauna samples from the Bathyal Northeast Atlantic Sarsia 71, 275-287

Gooday, A.J. (1988) A benthic foraminiferal response to the deposition of phytodetritus in the deep-sea. Nature London 332, 70-73.

Gooday, A.J. (1990). Recent deep-sea agglutinated foraminifera: a brief review. In "Paleoecology Biostratigraphy, Paleoceanography and Taxonomy of Agglutinated Foraminifera" (C. Hemleben, W. Kaminski and D. B. Scott, eds), pp 271-304. NATO ASI Series, Vol. C237. Kluwer, Dordrecht.

Gooday, A.J. and Lambshead, P.J.D. (1989). Influence of seasonally deposited phytodetritus on benthic foraminiferal populations in the bathyal northeast Atlantic: the species response. Marine Ecology Progress Series 58, 53-67.

Gooday, A J. and Turley, C.M. (1990). Responses by benthic organisms to inputs of organic material to the ocean floor: a review. Philosophical Transactions of the Royal Society of London A 331, 119-138.

Graf, G. (1992). Benthic-pelagic coupling : a benthic view. Oceanography and Marine Biology Annual Review 30, 149-190.

Graf, G., Bengtson, W., Diesner, U., Schulz, R and Theede, H. (1982) Benthic response to sedimentation of a spring phytoplankton bloom: process and budget. Marine Biology 67, 201-220.

Graf, G. Schulz, R., Peinert, R. and Meyer-Reil, L -A. (1983). Benthic response to sedimentation events during autumn to spring at a shallow-water station in the Western Kiel Bight. Marine Biology 77, 235-246.

Grassle, J.F. and Maciolek N.J. (1992). Deep-sea species richness: regional and local diversity estimates from quantitative bottom samples. American Naturalist 139, 313-341.

Grassle, J.F. and Mosse-Porteous, L.S. (1987). Macrofaunal colonization of disturbed deep-sea environments and the structure of deep-sea benthic communities. Deep-Sea Research 34, 1911-1950.

Gray, J.S. (1974). Animal-sediment relationships. Oceanography and Marine Biology Annual Review 12, 223-261.

Gross, T.F., Williams, A.J. and Nowell, A R.M. (1988). A deep-sea sediment transport storm. Nature (London), 331, 518-520.

Hansen, S.D. (1978). Nahrung und Fressverhalten bei Sedimentfressern dargestellt am Beispiel von Sipunculiden und Holothurien. Helgoländer wissenschaftlichen Meeresuntersuchungen 31, 191-221.

Heip, C., Vincx, M and Vranken, G. (1985). The ecology of marine nematodes. Oceanography and Marine Biology Annual Review 23, 399-489.

Hessler, R. R. and Jumars, P.A. (1974). Abyssal community analysis from replicate box cores in the central North Pacific. Deep-Sea Research 21, 185-209.

Hill, P.R. (1987). Characteristics of sediments from Feni and Gardas drifts, sites 610 and 611, Deep Sea Drilling Project Leg 94. Initial Reports Deep Sea Drilling Program 94, 1075-1082.

Hollister, C.D. and McCave, I.N. (1984). Sedimentation under deep-sea storms Nature London 309, 220-225. 
Huggett, P J (1986). Mapping of hemipelagic versus turbiditic muds by feeding traces observed in deep-sea photographs. In "Geology and Geochemistry of Abyssal Plains" (P.P.E. Weaver and J. Thomson, eds), pp. 105-112. Geological Society, Special Publication 31.

Jacobi, R.D (1976) Sediment slides on the northwestern continental margin of Africa Marine Geology 22, 157-173.

Jensen, P. (1988). Nematode assemblages in the deep-sea benthos of the Norwegian Sea. Deep-Sea Research 35, 253-266.

Jensen, $\mathbf{P}_{\text {, }}$, Rumohr, J and Graf, $\mathbf{G}_{\text {. (1992). Sedimentological and biological }}$ differences across a deep-sea ridge exposed to advection and accumulation of fine-grained particles. Oceanologica Acta 15, 287-296.

Kidd, R. B. and Huggett, Q...J. (1981) Rockdebris on abyssal plains in the Northeast Atlantic: a comparison of epibenthic sledge hauls and photographic surveys. Oceanologica Acta 4, 99-104.

Kidd, R.B., Hunter, P.M and Simm, R.W. (1986). Turbidity-current and debris-flow pathways to the Cape Verde Basin: status of long-range side-scan sonar (GLORIA). In "Geology and Geochemistry of Abyssal Plains" (P.P.E. Weaver and J. Thomson, eds), pp. 33-48. Geological Society Special Publication 31.

Klein, H. and Mittelstaedt, E. (1992). Currents and dispersion in the abyssal Northeast Atlantic. Results from the NOAMP field program. Deep-Sea Research 39, 1727-1745.

Kornicker, L.S. (1989). Bathyal and abyssal myodocopid ostracoda of the Bay of Biscay and vicinity. Smithsonian Contributions to Zoology 461, 1-134.

Lambshead, P. J.D. and Gooday, A.J. (1990). The impact of seasonally deposited phytodetritus on epifaunal and shallow infaunal benthic foraminiferal populations in the bathyal north-east Atlantic: the assemblage response. Deep-Sea Research 37A, 1263-1283

Lampitt, R.S. (1985). Fast living on the ocean floor. New Scientist 1445, 37-40.

Lampitt, R.S., Billett, D.S.M. and Rice, A.L. (1986). Biomass of the invertebrate megabenthos from 500 to $4100 \mathrm{~m}$ in the northeast Atlantic Ocean. Marine Biology 93, 69-81.

Linke, P. (1992). Metabolic adaptations of deep-sea benthic foraminifera to seasonally varying food input. Marine Ecology Progress Series 81, 51-63

Lochte, K (1992). Bacterial standing stock and consumption of organic carbon in the benthic boundary layer of the abyssal North Atlantic. In "Deep-sea Food Chains and the Global Carbon Cycle" (G.T. Rowe and V. Pariente, eds), pp. 1-10. Kluwer, Dordrecht.

Lutze, G.F. and Thiel, H. (1989). Epibenthic foraminifera of elevated microhabitats: Cibicidoides wuellerstorfi and Planulina ariminensis. Journal of Foraminiferal Research 19, 153-158.

Mart, Y., Auffret, G.A., Auzende, J.M. and Pastouret, L. (1979) Geological observations from a submersible on the western continental slope of the Ametican Massif. Marine Geology 31, 61-68.

Masson, D. G. Kidd, R.B., Gardner, J.V., Huggett, Q..J and Weaver, P.P.E. (1994). Saharan continental rise: facies distribution and sediment slides. In "Geological Evolution of Atlantic Continental Rises" (V.W. Poag and P.C. Degrocianski, eds), pp. 3-10. Van Nostrand Reinhold, New York.

McCave, N. (1991). Deep flashes reveal fluffing beds. BOFS News and Views 5, 5-6.

Murray, J.W. (1991) "Ecology and Palaeoecology of Benthic Foraminifera". Longman, Harlow. 
Norris, S. and McDonald, N. (1986). Current meter observations near the Porcupine Bank 1981-1983. Ministry of Agriculture, Fisheries and Food. Directorate of Fisheries Research Lowestoft, Fisheries Data Report 8, 103 pp.

Pace, M.L., Knauer, G.A., Karl, D.M and Martin, J.H. (1987), Primary production, new production and vertical flux in the eastern Pacific Ocean. Nature, London, 325, 803-804.

Parker, W.K and Jones, T R. (1856). On some Foraminifera of the North Atlantic and Arctic Oceans, including Davis Straits and Baffin Bay. Philosophical Transactions of the Royal Society of London 155, 325-441.

Patterson, D. J., Larsen, J and Corliss, J. O. (1982). The ecology of heterotrophic flagellates and ciliates living in marine sediments. Progress in Protistology 3.

Pfannkuche, O (1985). The deep-sea meiofauna of the Porcupine Seabight and abyssal plain (NE Atlantic): population structure, distribution, standing stocks. Ocèanologica Acta 8(3), 343-353.

Pfannkuche, O. (1992). Organic carbon flux through the benthic community in the temperate abyssal northeast Atlantic. In "Deep-Sea Food Chains and the Global Carbon Cycle" (G.T. Rowe and V. Pariente, eds), pp. 183-198, Kluwer, Dordrecht.

Pfannkuche, O (1993a). Benthic standing stock and metabolic activity in the bathyal Red Sea from $17^{\circ} \mathrm{N}$ to $27^{\circ} \mathrm{N}$. P.S.Z. N. I., Marine Ecology 14, 67-79.

Pfannkuche, O. (1993b). Benthic response to the sedimentation of particulate organic matter at the BIOTRANS station, $47^{\circ} \mathrm{N}, 20^{\circ} \mathrm{W}$. Deep-Sea Research II, 40, 135-149.

Pfannkuche, O. and Thiel, H. (1987). Meiobenthic stocks and benthic activity on the NE-Svalbard Shelf and in the Nansen Basin. Polar Biology 7, 253-266.

Pfannkuche, $\mathrm{O}$. and Thiel, $\mathrm{H}$. (1988). Chapter 9. Sample processing. In

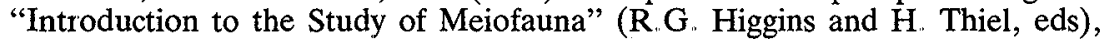
pp. 134-145. Smithsonian Institute Press, Washington DC.

Pfannkuche, $\mathrm{O}$, Theeg, $\mathrm{R}$. and Thiel, $\mathrm{H}$. (1983). Benthos activity, abundance and biomass under an area of low upwelling off Morocco, Northwest Africa. "Meteor" Forschungsergebnisse 36, 85-96

Pfannkuche, O., Beckman, W., Christiansen, B., Lochte, K., Rheinheimer, G., Thiel, H. and Weikert, H. (1990). BIOTRANS, Biologisches vertikaltransport und energiehaushault in der bodennahen Wasserschicht der Tiefsee. Berichte aus dem Zentrum für Meeres- und klimaforschung der Universität Hamburg 10, $159 \mathrm{pp}$

Rachor, E (1975). Quantitative Untersuchungen über das Meiobenthos der nordostatlantischen Tiefsee. "Meteor" Forschungsergebnisse D 21, 1-10

Renaud-Mornant, J. (1989), Espèces nouvelles de Florarctinae de l'Atlantique Nord-est et du Pacifique Sud (Tardigrada, Arthrotardigrada). Bulletin du Muséum national d'Histoire naturelle, Paris, 4th series 11, A, 571-592.

Renaud-Mornant, J. and Gourbault, N. (1990). Evaluation of abyssal meiobenthos in the eastern central Pacific (Clarion-Clipperton fracture zone). Progress in Oceanography 24, 317-329.

Rice, A.L and Lambshead, P.J.D. (1993). Patch dynamics in the deep-sea benthos: the role of a heterogeneous supply of organic matter. Proceedings of British Ecological Society/American Society of Limnology and Oceanography Symposium on "Aquatic ecology: scale pattern and process", University College, Cork, April 1992.

Rice, A.L., Billett, D.S.M., Fry, J. John, A.W.G., Lampitt, R.S., Mantoura, R.F.C. and Morris, R.J. (1986). Seasonal deposition of phytodetritus to the deep-sea floor. Proceedings of the Royal Society of Edinburgh 88B, 265-279. 
Rice, A.L., Billett, D.S.M., Thurston, M.H. and Lampitt, R.S. (1991). The Institute of Oceanographic Sciences Biology Programme in the Porcupine Seabight: background and general introduction. Journal of the Marine Biological Association of the UK 71, 281-310.

Richardson, M.J., Wimbush, M. and Mayer, L. (1981). Exceptionally strong near-bottom flows on the continental rise off Nova Scotia. Science 213, $887-888$.

Riemann, F. (1974). On hemisessile nematodes with flagelliform tails living in marine soft bottoms and on micro-tubules found in deep-sea sediments. Microfauna des Meeresbodens 40, 1-15.

Robinson, M.K., Bauer, R.A and Schroeder, E. (1979). Atlas of North Atlantic-Indian Ocean monthly mean temperatures and mean salinities of the surface layer. U.S. Naval Oceanographic Office, Reference Publication 18, 1-17.

Romano, J.-C. and Dinet, A. (1981). Relation entre l'abondance du méiobenthos et la biomasse des sédiments superficiels estimée par la mesure des adénosines 5'phosphate (ATP, ADP, AMP). In "Géochimie organique des sédiments marins profonds, ORGON IV, golfe d'Aden, mer d'Oman", pp. 159-180. CNRS, Paris.

Rona, P.A. (1980). The Central North Atlantic Ocean basin and continental margin: geology, geophysics, geochemistry and resources, including the TransAtlantic Geotraverse (TAG). NOAA Atlas 3. NOAA Environmental Research Laboratories.

Rutgers van der Loeff, M. M. (1991). Oxygen in pore waters of deep-sea sediments. Philosophical Transactions of the Royal Society of London A331, 69-84

Rutgers van der Loeff, M.M and Lavaleye, M.S S (1986). Sediments, fauna and the dispersal of radionuclides at the N.E. Atlantic dumpsite for low-level radioactive waste. Report of the Dutch DORA program. Netherlands Institute for Sea Research, pp. 1-134.

Schnitker, D. (1980). Quaternary deep sea foraminifers and bottom water masses. Annual Review of Earth and Planetary Sciences 8, 343-370

Schriever, G., Bussau, C. and Thiel, H. (1991). DISCOL-Precautionary environmental impact studies for future manganese nodule mining and first results on meiofauna abundance. Proceedings and Advances of the Marine Technology Conference 4, 47-57.

Shirayama, Y. (1983). Size-structure of deep-sea meiobenthos in the western Pacific. International Revue des gesamten Hydrobiologie 68, 799-810.

Shirayama, Y. (1984a). The abundance of deep-sea meiobenthos in the Western Pacific in relation to environmental factors. Oceanologica Acta 7, 113-121

Shirayama, Y. (1984b). Vertical distribution of meiobenthos in the sediment profile in bathyal, abyssal and hadal deep-sea systems in the Western Pacific. Oceanologica Acta 7, 123-129

Sibuet, M. (1984). Quantitative distribution of echinoderms (Holothurioidea, Asteroidea, Ophiuroidea, Echinoidea) in relation to organic matter in the sediment, in deep sea basins of the Atlantic Ocean. "Proceedings Fifth International Echinoderm Conference, Galway, 24-29 September 1984" (B.F. Keegan and B.D.S. O'Connor, eds), pp. 99-108. A A Balkema, Rotterdam.

Sibuet, M., Monniot, C., Desbruyeres, D., Dinet, A., Khripounoff, A., Rowe, G. and Segonzac, M. (1984). Peuplements benthiques et characteristiques trophiques du milieu dans la plaine abyssale de Demerara dans l'ocean Atlantique. Ocèanologica Acta 7, 345-358.

Sibuet, M., Lambert, C.E., Chesselet, R. and Laubier, L. (1989). Density of the 
major size groups of benthic fauna and trophic input in deep basins of the Atlantic Ocean. Journal of Marine Research 47, 851-867.

Smart, C.W., King, S.C., Gooday, A.J., Murray, J.W. and Thomas, E. (1994). A benthic foraminiferal proxy of pulsed organic matter paleofiuxes. Paleoceanography, in press.

Snider, L.J., Burnett, B. R and Hessler, R. R. (1984). The composition and distribution of meiofauna and nanobiota in a central North Pacific deep-sea area. Deep-Sea Research 31, 1225-1249.

Soetaert, K., Heip, C. and Vincx, M. (1991a). The meiobenthos along a Mediterranean deep-sea transect off Calvi (Corsica) and in an adjacent canyon. $P_{\text {. }} S_{\text {. }} Z_{\text {. }} N_{\text {. }}$., , Marine Ecology 12(3), 227-242.

Soetaert, K., Heip, C and Vincx, M. (1991b). Diversity of nematode assemblages along a Mediterranean deep-sea transect. Marine Ecology Progress Series $75,275-282$.

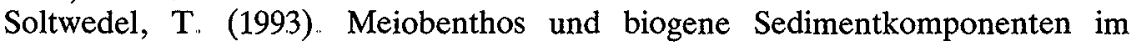
tropischen Ost-Atlantik. Berichte aus dem Zentrum für Meeres- und Klimaforschung der Universität Hamburg 13, $178 \mathrm{pp}$.

Sorensen, J. and Wilson, T.R.S (1984) A headspace technique for oxygen measurements in deep-sea sediment cores. Limnology and Oceanography 29, $650-652$.

Stein, R. (1991). "Accumulation of Organic Carbon in Marine Sediments". Lecture Notes in Earth Sciences 34, $217 \mathrm{pp}$. Springer, Berlin.

Streeter, S. (1973) " Bottom water and benthonic foraminifera in the North Atlantic-Glacial-Interfacial contrasts Quaternary Research 3, 131-141.

Thiel, H. (1966). Quantitative Untersuchungen über die Meiofauna des Tiefseebodens. Veröffenlichungen des Institut für Meeresforschungen Bremerhaven (Sonderband) 2, 131-148.

Thiel, H. (1972a). Meiofauna und Struktur der benthischen Lebensgemeinschaft des Iberischen Tiefseebeckens. "Meteor" Forschungsergebnisse D 12, 36-51

Thiel, H. (1972b). Die Bedeutung der Meiofauna in küsternfernen benthischen Lebensgemeinschaften verschiedener geographischer Regionen. Verhandlungsbericht der Deutschen zoologische Gesellschaft 65, 42-57.

Thiel, H. (1975). The size structure of the deep-sea benthos. International Revue des gesamten Hydrobiologie 60, 575-606.

Thiel, H. (1978). Benthos in upwelling regions. In "Upwelling Ecosystems" (R. Boje and $\mathrm{M}$. Tomczak, eds), pp. 124-138 Springer, Berlin.

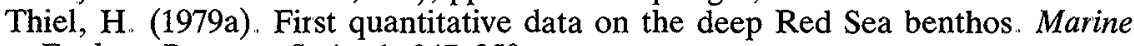
Ecology Progress Series 1, 347-350.

Thiel, H. (1979b). Structural aspects of deep-sea benthos. Ambio Special Report 6, 25-31.

Thiel, H. (1982). Zoobenthos of the CINECA area and other upwelling regions. Rapport et Procès-Verbaux des Réunions du Conseil International pour l'Exploration de la Mer 180, 323-334.

Thiel, H. (1983) Meiobenthos and nanobenthos of the deep-sea "In "Deep-sea Biology" (G.T. Rowe, ed), pp. 167-230. Wiley, New York.

Thiel, H. (1993). Benthos size classification. Deep-Sea Newsletter 20, 8-11.

Thiel, H., Pfannkuche, O., Theeg, R and Schriever, G. (1987). Benthic metabolism and standing stock in the central and northern Red Sea. P.S.Z.N.I., Marine Ecology 8, 1-20.

Thiel, H. Pfannkuche, O., Schriever, G., Lochte, K., Gooday, A.J., Hemleben, C., Mantoura, R.F.C., Turley, C.M., Patching, J.W. and Rieman, F. (1989- 
1990). Phytodetritus on the deep-sea floor in a central oceanic region of the northeast Atlantic. Biological Oceanography 6, 203-239.

Thistle, D. (1983). The role of biologically produced habitat heterogeneity in deep-sea diversity maintenance. Deep-Sea Research 30, 1235-1245.

Thistle, D and Eckman, J.E (1988). Response of harpacticoid copepods to habitat structure at a deep-sea site. Hydrobiologia 167/168, 143-149.

Thistle, D and Sherman, K. (1985). The nematode fauna of a deep-sea site exposed to strong near-bottom currents. Deep-Sea Research 32, 1077-1088.

Thistle, D., Yingst, J.Y. and Fauchald, K (1985). A deep-sea benthic community exposed to strong near-bottom currents on the Scotian Rise (Western Atlantic). Marine Geology, 66, 91-112.

Tietjen, J.H. (1971). Ecology and distribution of deep-sea meiobenthos off North Carolina. Deep-Sea Research 18, 941-957.

Tietjen, J.H. (1976). Distribution and species diversity of deep-sea nematodes off North Carolina Deep-Sea Research 23, 755-768.

Tietjen, J.H. (1984). Distribution and species diversity of deep-sea nematodes in the Venezuela Basin. Deep-Sea Research 31(2), 119-132.

Tietjen, J.H. (1989). Ecology of deep-sea nematodes from the Puerto Rico Trench area and Hatteras Abyssal Plain. Deep-Sea Research 36, 1567-1577.

Tietjen, J.H. (1992). Abundance and biomass of metazoan meiobenthos in the deep-sea In "Deep-Sea Food Chains and the Global Carbon Cycle" (G.T. Rowe and V. Pariente, eds), pp. 45-62. Kluwer, Dordrecht.

Tietjen, J.H., Deming, J.W., Rowe, G.T., Macko, S and Wilke, R.J. (1989). Meiobenthos of the Hatteras Abyssal Plain and Puerto Rico Trench: abundance, biomass and associations with bacteria and particulate fluxes. Deep-Sea Research 36, 1567-1577.

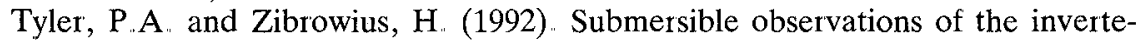
brate fauna on the continental slope southwest of Ireland (NE Atlantic ocean) Oceanologica Acta 15, 211-226.

Udintsev, G.B. (1989-1990). "International Geological-Geophysical Atlas of the Atlantic Ocean" IOC (of UNESCO), Min. Geol USSR, Ac. Sci USSR, GUGK USSR Moscow

Vangreisheim, A (1985). Hydrologie et circulation profonde In "Peuplements profonds du Golfe de Gascogne" (L. Laubier and C. Monniot, eds), pp. 43-70 IFREMER, Paris

van Harten, D (1990). Modern abyssal ostracod faunas of the eastern MidAtlantic Ridge area in the North Atlantic and a comparison with the Mediterranean. In "Ostracoda and Global Events" (R. Whatley and C. Maybury, eds), pp. 321-328. Chapman \& Hall, London.

Vanreusel, A., Vincx, M., Van Gansbeke D and Gijselinck, W. (1992). Structural analysis of the meiobenthos communities of the shelf break area in two stations of the Gulf of Biscay (N.E Atlantic). Belgian Journal of Zoology 122, 185-202.

c. Vivier, M.H. (1978). Influence d'un déversement industriel profond sur la nématofaune (canyon de Cassidaigne, Méditerranée). Téthys 8(4), 307-321.

Wallace, H.E., Thomson, J., Wilson, T R.S., Weaver, P.P.E, Higgs, N.C and Hydes, D J (1988). Active diagenetic formation of metal-rich layers in the northeast Atlantic sediments. Geochemica et Cosmochimica Acta 52, 15571569.

Weaver, P.P.E and Kuijpers, A (1983) Climate control of turbidite deposition on the Madeira Abyssal Plain. Nature, London 306, 360-363. 
Weaver, P.P.E., Searle, R.C. and Kuijpers, A. (1986) Turbidite deposition and the origin of the Madeira Abyssal Plain. In "North Atlantic Palaeoceanography" (C.P. Summerhayes and N.J. Shackleton, eds), pp. 131-143. Geological Society Special Publication 21.

Weston, J F. (1985). Comparison between recent benthic foraminiferal faunas of the Porcupine Seabight and western approaches continental slope. Journal of Micropaleontology 4, 165-183.

Weston, J.F. and Murray, J.W. (1984). Benthic foraminifera as deep-sea water mass indicators. In "Benthos '83, 2nd International Symposium on Benthic Foraminifera, Paris, April 1983" (H.J. Oerbli, ed.), pp. 605-610.

Wieser, W. (1953). Beziehungen zwischen Mundhölengestalt, Ernährungsweise und Vorkommen bei freilebenden marinen Nematoden. Archive der Zoologie (2) 4, 439-484

Wigley, R.L. and McIntyre, A.D. (1964), Some quantitative comparisons of offshore meiobenthos and macrobenthos south of Martha's Vineyard Limnology and Oceanography 9, 485-493.

Wilson, T.R.S and Wallace, H.E. (1990). The rate of dissolution of calcium carbonate from the surface of deep-ocean turbidite sediments. Philosophical Transactions of the Royal Society of London A 331, 41-49.

Wilson, R R., Smith, J R., Rosenblatt, K L . (1985). Megafauna associated with bathyal seamounts in the central North Pacific Ocean. Deep-Sea Research 32, $1243-1254$

Wilson, T.R.S., Thomson, J., Hydes, D J., Colley, S., Culkin, F and Sorensen, J. (1986). Oxidation fronts in pelagic sediments: diagenetic formation of metal-rich layers. Science 232, 972-975.

Woods, D.R and Tietjen, J.H. (1985). Horizontal and vertical distribution of meiofauna in the Venezuela Basin. Marine Geology 68, 233-241.

Worthington, L. V. (1976) "The North Atlantic Circulation". Johns, Hopkins University Press, Baltimore. 